\title{
استراتيجيات التعلم المثظم ذاتيا وعلاقتها بالتحصيل الدراسي لدى طلاب مراحل التعليم العام
}

\author{
إعراد \\ الباحثة/ سارة محمد عباس القبرصلي
}

$$
\text { إشراف }
$$

$$
\begin{aligned}
& \text { أ.د. عبد الناصر أنيس عبد الوهاب د.عصام الدسوقي الجبل }
\end{aligned}
$$

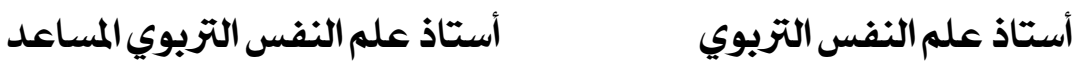

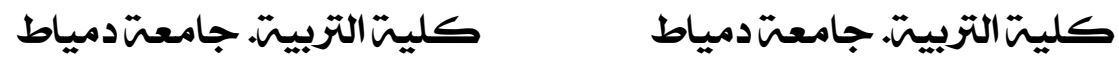

$$
\begin{aligned}
& \text { المجلت العلميت لكليتت رياض الأطفالـ جامعت المنصورة } \\
& \text { المجلد الثالثـ العدد الرابع } \\
& \text { ابريل r. Tr }
\end{aligned}
$$




\section{استراتيجيات التعلم المنظم ذاتيا وعلاقتها بالتحصيل الدراسي لدى طلاب مراحل التعليم العام}

أ.م.د / سارة محمد عباس القبرصلي **

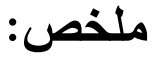

هدفت الدراسة إلى الكثف عن درجة امتلاك طلاب مر احل التعليم العام

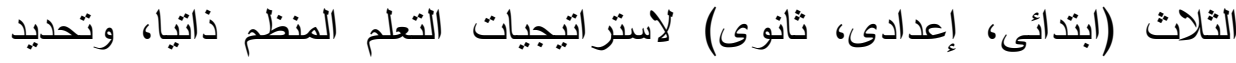
العلاقة بين استر اتيجيات التعلم المنظم ذاتيا و التحصيل الدر اسى وفق متغيرى

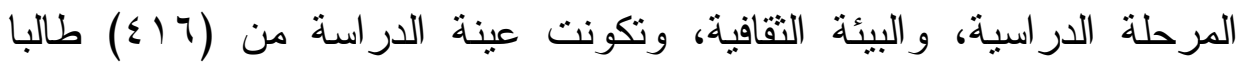

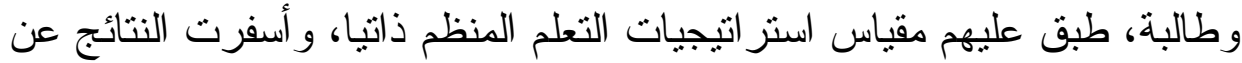
استخدام طلاب كل مرحلة من مراحل التعليم العام (ابتدائي، إعدادي، ثنانوي)

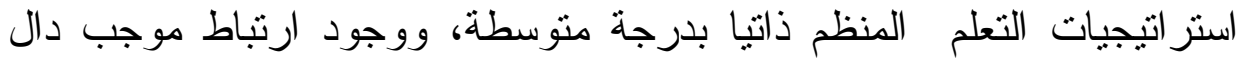

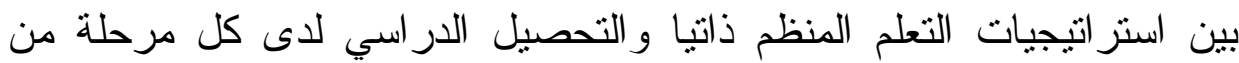
المراحل الثلاث، ولم تختلف هذه العلاقة بين استراتيجيات التعلم المنظم ذاتيا

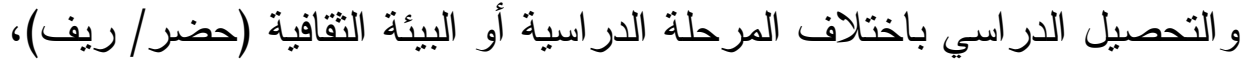

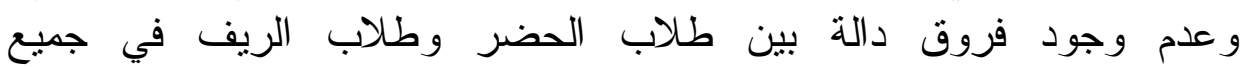

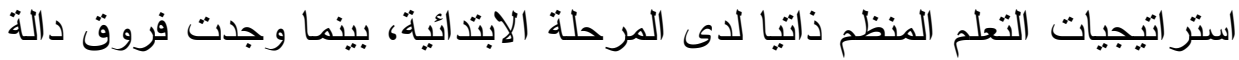
بين طلاب الحضر وطلاب الريف في معظم استر اتيجيات التعلم المنظم ذاتيا لاى المرحلة الإعدادية لصالح طلاب الحضر عدا استر اتيجية مكافأة الذات، كما وجدت فروق دالة بين طلاب الحضر وطلاب الريف في معظم استر اتيجيات التعلم المنظم ذاتيا لدى المرحلة الثانوية لصالح طلاب الحضر طدر عدا استر اتيجية

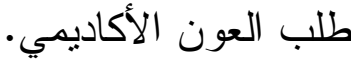

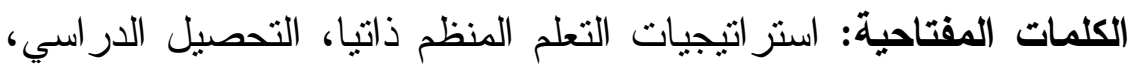
مر احل التعليم العام (المرحلة الابتدائية، المرحلة الإعدادية، المرحلة الثانوية)، الثية،

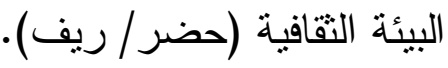

"باحثتماجستير بقسم علم النفس التوبوي_كليت التربيتة. جامعت دمياط 


\section{Abstract \\ Self-Regulated Learning Strategies and Their \\ Relationship With Academic Achievement Among General Education Students}

The study aimed at identifying the degree of ownership of the three stages of general education (primary, preparatory and secondary) of self-regulated learning strategies, and determining the relationship between self- regulated learning strategies and academic achievement according to the variables of the school stage and the cultural environment. The sample consisted of (416), The scale of self- regulated learning strategies has been applied to them. The results showed that students at each stage of general education (primary, preparatory, secondary) used moderately selfregulated learning strategies, and a positive correlation between self-regulated learning strategies and academic achievement at each of the three stages, This relationship did not differ between selfregulated learning strategies and academic achievement depending on the stage of study or the cultural environment (rural / urban), And the absence of differences between urban students and rural students in all self- regulated learning strategies at the primary level, while found significant differences between urban students and rural students in most of self- regulated learning strategies at the preparatory level for the benefit of urban students except selfconsequation strategy, and found significant differences between students urban and rural students in most of self- regulated learning strategies at the secondary level for the benefit of urban students except - Seeking Academic Help strategy.

Keywords: Self- Regulated Learning Strategies, Academic Achievement, General Education (Primary, Preparatory, Secondary), Cultural Environment (Urban / Rural). 


\section{استراتيجيات التعلم المنظم ذاتيا وعلاقتها بالتحصيل الدراسي لدى طلاب مراحل التعليم العام}

**

أ.م.د / سارة محممد عباس القبرصلي

مقدمة:

يعد التحصيل الدر اسي من أهم النواتج الأساسية في العملية التعليمية، فهو محصلة التعليم ومؤشر للنجاح، كما أنه المدى الذي يحقق عنده الطالب أو المعلم أو المؤسسة أهدافهم التعليمية، فكلمة تحصيل در اسي تعنى في مفهومها العام "مقدار المعلومات التي يحصل عليها الطالب خلال دراسته"، وتتداخل العو امل المختلفة مع التحصيل الدراسي، ومن تلك العوامل، عوامل متعلقة بالظروف البيئية التي تحيط بالمتعلم من أسرة ومدرسة ومعلم، و عو امل مرتبطة بالطالب بـاب نفسه و بقدر اته وبدافعتيه، وبعضها مرتبط بالخبرة المكتسبة. وتتتوع العوامل التي تؤثر على التحصيل الدراسي منها الذكاء و أنماط التعلم وعادات الاستذكار و واستر اتيجيات التعلم و الدافعية، فتحديد مستوى التحصيل الدراسي ومستوى التقدم فيه يعتمد بشكل أساسي على مدى امتلاك الطالب لتلك المتغير ات و المهار ات، وكيفية تتميتها للتحقيق ارتفاع في معدلات التحصيل الدراسي له، مما يساعد على تحقيق الأهداف المنشودة من العملية التعليمة.

إن إعداد المتعلم القادر على القيام بدور إيجابي في عمليتي التعليم والتعلم يتطلب من علماء التزبية ضرورة البحث عن استر اتيجيات تعلم تساعد المــتعلم

$$
\text { *باحثت ماجستير بقسم علم النفس التربوي_ كليت التربيتة. جامعت دمياط }
$$


على تكوين معنى لما يتعلمه، و لا ينتظر أن يقدم له المعلــم الحــــــل الجــاهزة

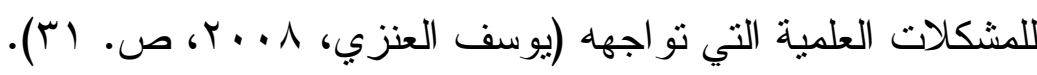
ويعد التعلم المنظم ذاتيا أحد لأساليب المستخدمة للتأكد من مــدى إتقــان الطلاب للمعلومات و المعارف المقررة عليهم، وذلك لأن آليات الــتعلم الـــنظم

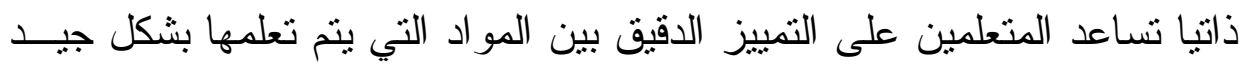

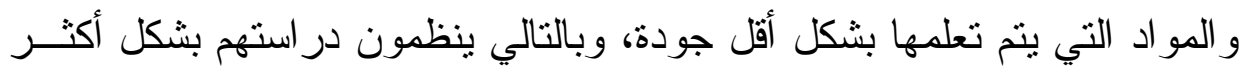
فاعلية، وبما يؤدى في النهاية إلى ارتفاع المستوى التحصيلي لديهم، وهو الهـف لئف

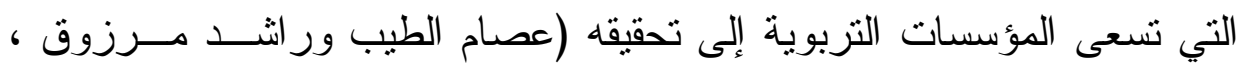

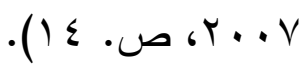

ويعود الاهتمام بهذا التوجه المعاصر في دراسة تعلم الطلاب إلى رفضض

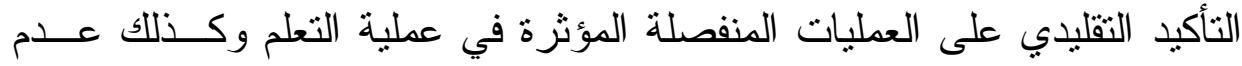

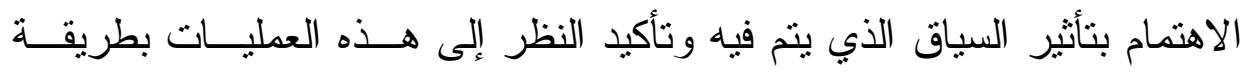

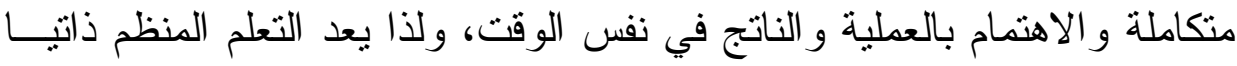
بمثابة القوة الدحركة التي يمكن بها العبور بالعملية التعليمية إلى العصر الحديث

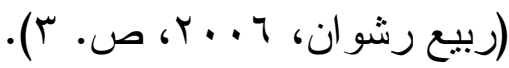

$$
\begin{aligned}
& \text { مشكلة الدراسة: }
\end{aligned}
$$

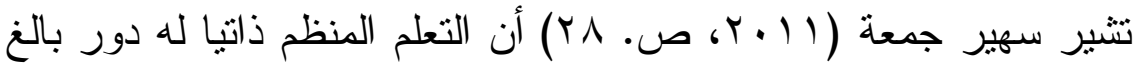

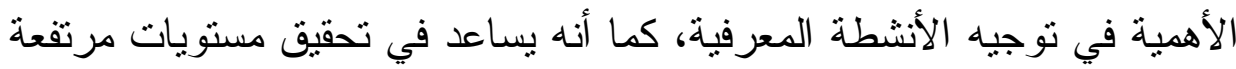

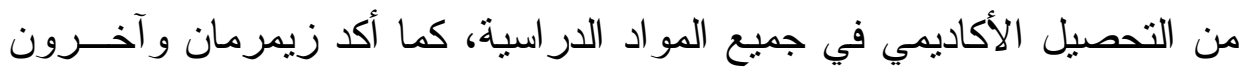

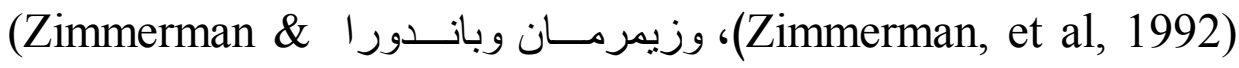

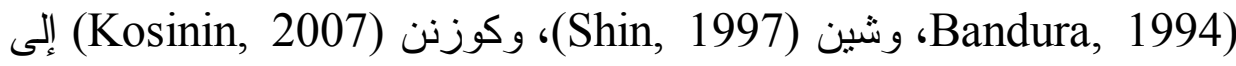
أن الطلاب الذين يوظفون استر اتيجيات التعلم المنظم ذاتيا يتميزون بأنهم أكثــر 
تقوقا في التحصيل الدراسي في المو اد المختلفة عن غير هم ممن لا يـستخدمون هذه الاستر اتيجيات.

ونتيجة اعتماد التحصيل الدر اسي بشكل قوى علــى إمكانيــات وقــدرات

الطالب ومستوى المهار ات التي يستخدمها من أجل تحقبــق أهدافــهـ و وانجاز اتــهـ

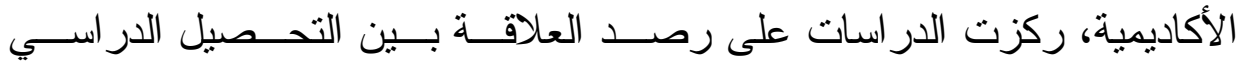
و المتغير ات الداخلية للمتعلم، ومن تلك المتغير ات استر اتيجيات الــتعلم المــنظ

وتضاربت نتائج البحوث و الدر اسات فيما يخص العلاقة بين التعلم المنظم

ذاتيا و التحصيل الدر اسي؛ فقد توصلت بعض الدراســات، منهـــا دراســـة شــن (Chen, 2002) ودر اسة أسماء عبد الحميد (11) (1) إلى وجود علاقة ارتباطية

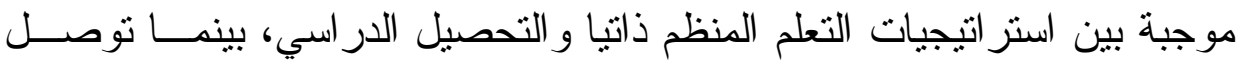

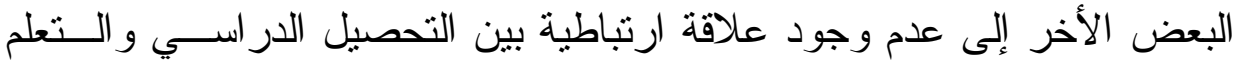

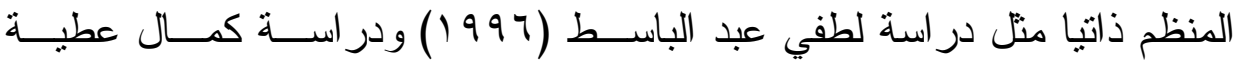

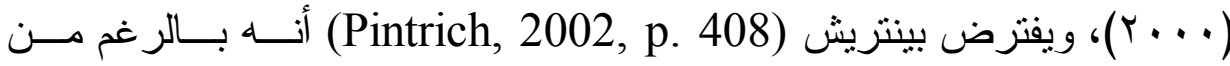
عدم وجود دليل إمبريقي خاص بالفروق في استر اتيجيات التعلم المـنظم ذاتيـــا تبعا للفروق العرقية، فمن المهر على أية حال أن نفحص بنيات المعرفة الأساسية

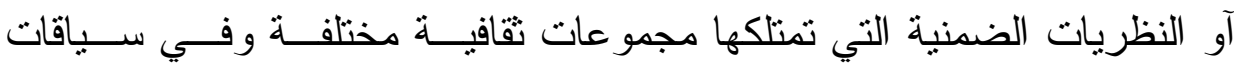
مختلفة.

وبناء على ما تقدم جاءت الدر اسة لمحاولة تعرف طبيعــة العلاقـــة بــين

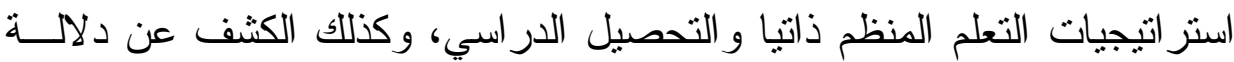
الفروق بين طلاب مدارس الحضر ومدارس الريف فــي اســتر اتيجيات الــتعلم

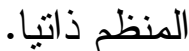


ويمكن صياغة مشكلة الارسة الحالية في الأسئلة التالية:

1- ما مستوى امتلاك طلاب كل مرحلة من مر احل التعليم العام لاستر اتيجيات

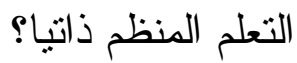

ץ-ما العلاقة بين استر اتيجيات التعلم المنظم ذاتيا و التحصيل الدراسي لدى

طلاب كل مرحلة من مر احل التعليم العام (ابتدائي، إعدادي، ثانوي)؟

r- هل تختلف العلاقة بين استر اتيجيات التعلم المنظم ذاتيا و التحصيل الدراسي

باختلاف مر احل التعليم العام (ابتدائي، إعدادي، ثانوي)؟

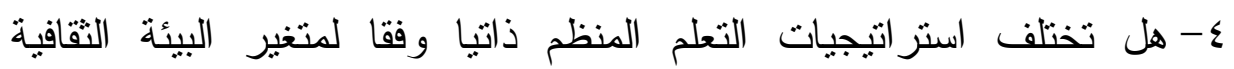

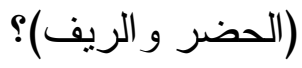

ه- هل تختلف العلاقة بين استر اتيجيات التعلم المنظم ذاتيا و التحصيل الدراسي

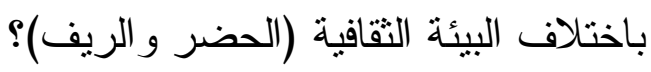

أهداف الار اسة:

\section{تهاف الارسة الحالية إلى ما يلي:}

1- التعرف على درجة امتلاك طلاب كل مرحلة من مراحل التعليم العام

(ابتدائي، إعدادي، ثانوي) لاستر اتيجيات التعلم المنظم ذاتيا.

ץ- الكثف عن دلالة العلاقة بين استر اتيجيات التعلم المنظم ذاتيا والتحصيل

الدر اسي لدى طلاب مر احل التعليم العام (ابتدائي، إعدادي، ثانوي).

r- الكثف عن دلالة اختلاف العلاقة بين استراتيجيات التعلم المنظم ذاتيا

و التحصيل الدراسي باختلاف مراحل التعليم العام (ابتائي، إعدادي،

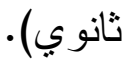

ع- الكثف عن دلالة اختلاف العلاقة بين استراتيجيات التعلم المنظم ذاتيا 
و التحصيل الدر اسي وفقا لمتغير البيئة الثقافية (الحضر و الريف) لدى طلاب مر احل التعليم العام (ابتدائي، إعدادي، ثانوي).

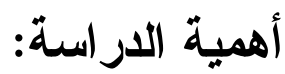

\section{تتبع أهمية الدراسة من أهمية المتغيرات التي تتناولها، حيث أنها:}

1- تؤكد على أهمية التعلم المنظم ذاتيا و استر اتيجياته ومهار اته خاصة في إطار ثورة المعلوماتية التي نعيشها.

r- تلبية حاجة المكتبة العربية لدر اسات تتتاول استر اتيجيات التعلم المنظم ذاتيا

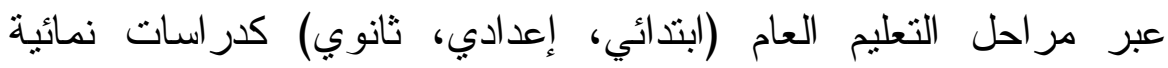
مستعرضة تكشف عن مدى تطور هذه الاستر اتيجيات و الحاجة لتوظيفها بمعرفة الطلاب في كل مرحلة.

r-تحديد استراتيجيات التعلم الأكثر توظيفا من قبل الطلاب في كل مرحلة

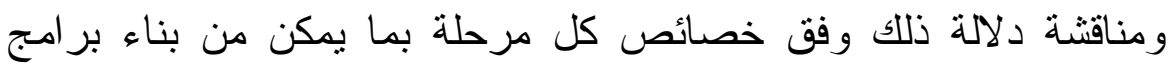

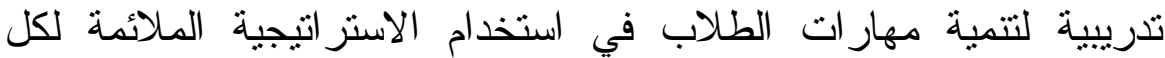
مرحلة.

ع- المساهمة في تحديد طبيعة العلاقة بين استراتيجيات التعلم المنظم ذاتيا و التحصيل الدر اسي حيث تعارض النتائج بشأنها.

ه- تحديد استر اتيجيات التعلم الأكثر توظيفا من قبل الطلاب في كل بيئة ثقافية (حضر / ريف) ومناقثة دلالة ذلك وفق خصائص كل بيئة بما يمكن من بناء برامج تدرييية لتتمية مهار ات الطلاب في استخدام الاستراتيجية التانية الملائمة لكل منها، حيث أن البيئة الثقافية ذات دور مؤثر على استخدام استر اتيجيات التعلم المنظم ذاتيا. 


\section{مصطحات الار اسة:}

تتحدد المصطلحات و الدفاهيم الاساسية للار اسة فيما يلى:

Self-Regulated Learning Strategies استر اتيجيات التعلم المنظم ذاتيا يعرف الباحثون استر اتيجيات التعلم المنظم ذاتياً في ظل أهداف هذه الدراسة و التعريفات بأنها تجمعات الإجراءات المنهجية المنظمة المعبرة عن العمليات التي يوظفها المتعلم لتحقيق أهدافه التعليمية مع إيجاد الدوافع المناسبة لتحقيق الإنجاز المطلوب من خلال ضبط وتوجيه قدراته لتتناسب مع متطلباته الأكاديمية. وتقاس إجرائيا بالدرجات التي يحصل عليها الطالب في الاستجابة

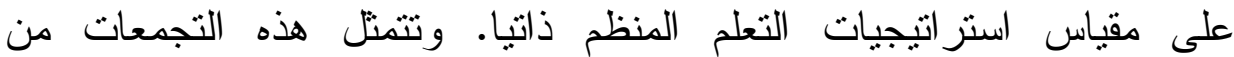
الإجراءات المنهجية المنظمة في التعبير عن واحدة أو أكثر من الاستر اتيجيات

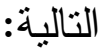
V- طلب العون أو المساعدة الأكاديمية

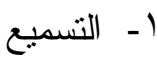
Seeking Academic Help

Time Management إدارة الوقت Rehearsal

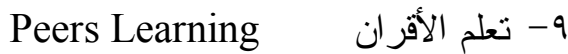
rMotivational ا- ا-ضنبط البيئي الدافعي Reviewing Environmental Structuring

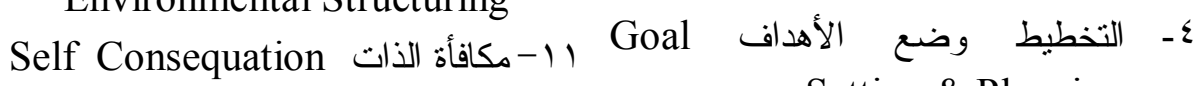
Interest الاهتصام Enhancement

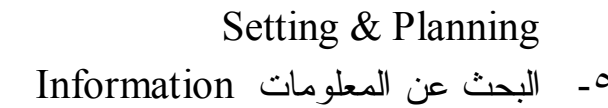
Organization r- الاحتفاظ بالسجلات Records Seeking T- النقويم الذاتي Self-Evaluation 


\section{Academic Achievement التحصيل الاراسي}

يعرف الباحثون التحصيل الدراسي بأنه: حصيلة المعارف و الدفاهيم و المهار ات التي يكتسبها المتعلم في موضوعات تعليمية سبق در استها وفق منهج تعليمي منظم، تخضع للقياس عن طريق الاختبار ات أو من قبل المعلمين ويقاس بالدرجة الكلية للمجموع الذى يحصل عليه الطالب في الاختبار ات النهائية للمو اد ادلين

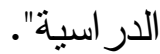

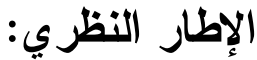

يستعرض الباحثون في الجزء التالي إطار ا مفاهيميا يصف مصطلحات الدر اسة ومتغير اتها، وبعض الدراسات السابقة، بما يمكن من تفسير ومناقتشة النتائج التي سيتم التوصل إليها. أولا: مفهوم التعلم المنظم ذاتيا

هنالك العديد من الاتجاهات النظرية التي حاولت دراسة التعلم المنظم ذاتيا وتفسبره، تمنلت في الاتجاه السلوكي الذي ركز على دور التعزيز الخارجي، في حين ركز الاتجاه المعرفي الاجتماعي على الصورة التي يرسمها الأفراد لأنفسهر بوصفهم متعلمين، كما ركز اتجاه معالجة المعلومات على الطريقة التي التي التياهي تتظم بها عمليات التخطيط، واختيار الاستر اتيجية المناسبة، أما الاتجاه البنائي المستتد إلى أعمال نظرية بياجيه Piaget، فيرى أن الصراع المعرفي هو أحد الآليات الأساسية المسئولة عن تطور مهار ات التعلم المنظم ذاتيا، وأخبر ا، يتتاول منحنى فيجوتيسكى تفسير ا يربط تطور الجانب المعرفي و التعلم المنظم ذاتيا بأنه نتيجة للتفاعلات الاجتماعبة مع الأقران والراشدين الأكثر خبرة، ويركز على الثى أهمية الدافعية في تلاك التفاعلات. 


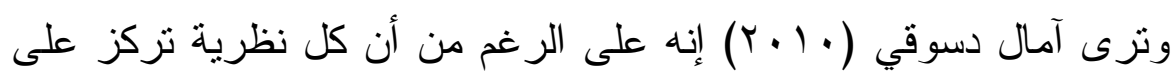

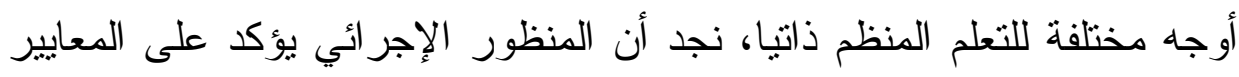

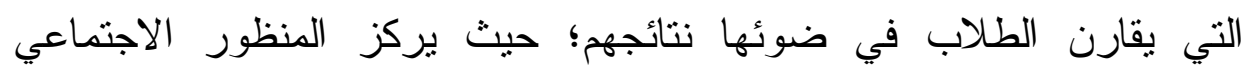

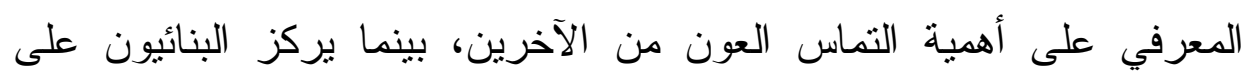

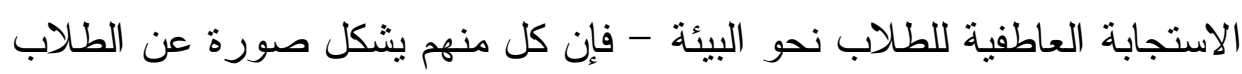
المنظمين ذاتيا الذين ير اقبون تعلمهم.

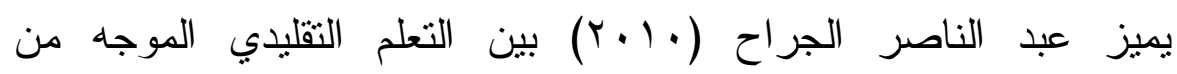

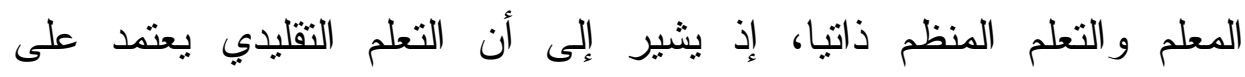

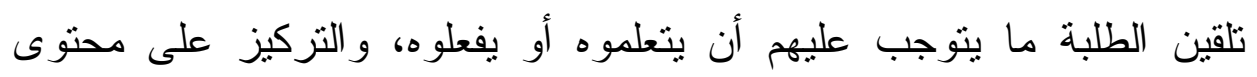

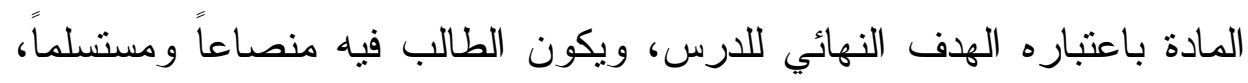

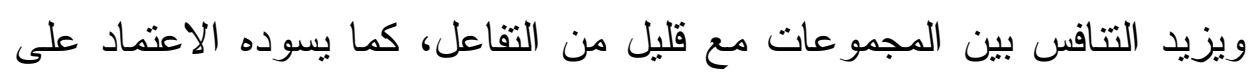
المعلم.

بينما يتمايز مفهوم التعلم المنظم ذاتيا عن غيره من المفاهيم التربوية

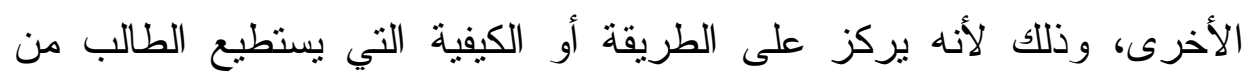

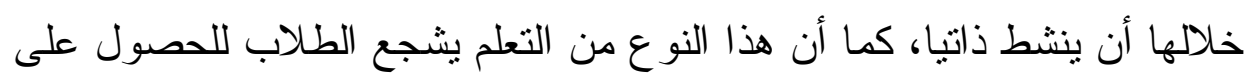

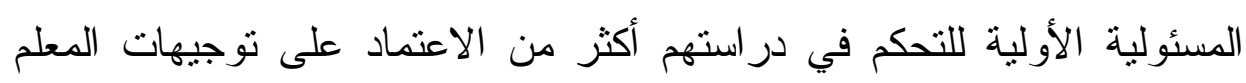

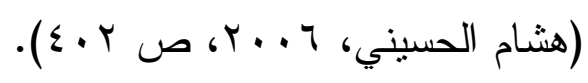

\section{أهمية التعلم المنظم ذاتيا}

تكمن أهمية النعلم المنظم ذاتيا في نوع الطلاب الذين يسعى إلي تكوينهم،

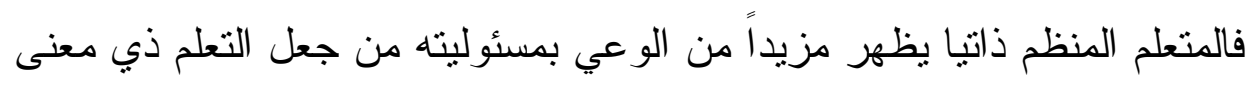

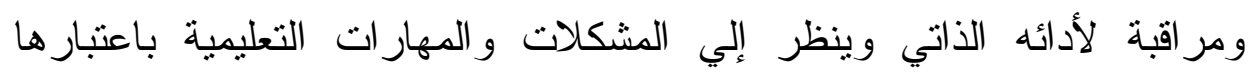
تحديات يرغب في مواجهتها و الاستمتاع في التعلم من خلالها، كما أن التعلم 
المنظم ذانيا بسهم في جعل الطالب لديه دافعية ومثابرة وثقة في نفسه بأنه

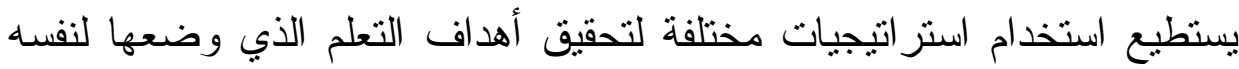

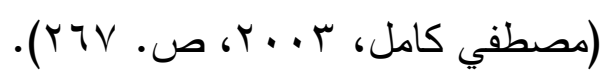

ويمكن القول أن التعلم المنظم ذاتيا يجعل التلاميذ يتسمون

بالأداء الأكاديمي المرتفع في مجال التحصيل الدراسي والكتساب المهارات، ويستثمرون التغذية الراجعة في تعديل مسار تعلمهم، وبالتالي يتسمون بالمرونة

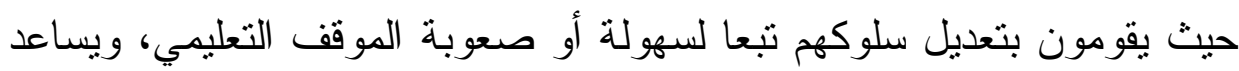
على توظيف العديد من الاستر اتيجيات المعرفية وما وراء المعرفية وتوظيف

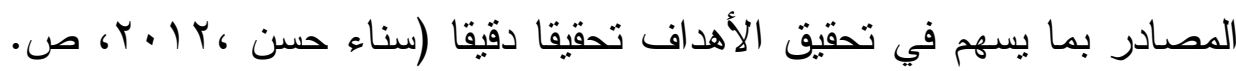

\section{استر اتيجيات التعلم المنظم ذاتيا}

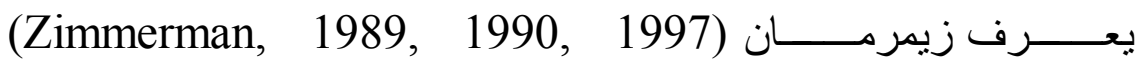

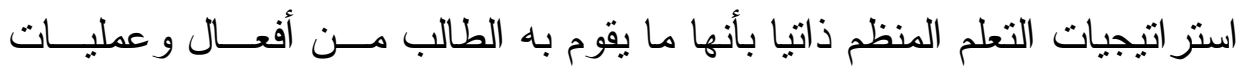

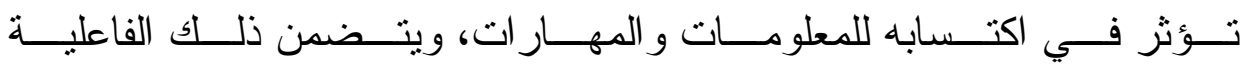

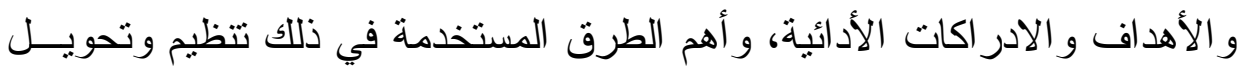

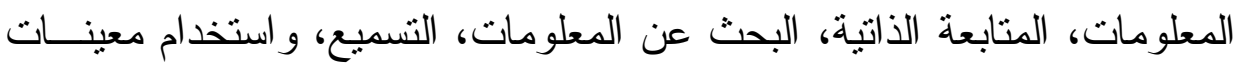

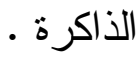

ويعـرف بينتــريش (Pintrich, 1999; 2000) اســتر اتيجيات الـتـعلم

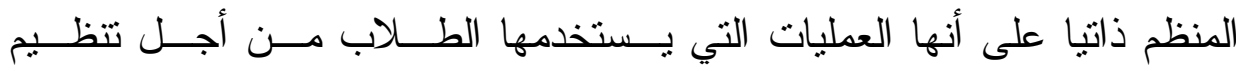

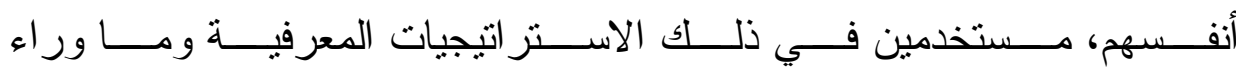

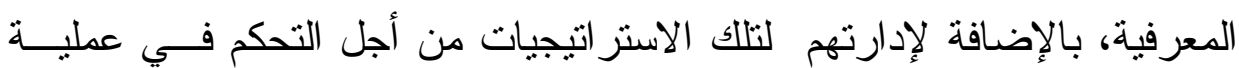

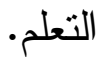




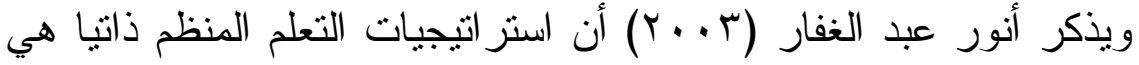
أنشطة يقوم بها المتعلم مدفوعاً برغبته الذاتية، وكفاءة فاعلة لتتمية استعداداته وقدر اته مستجيبا" لميوله و اهتماماته، و واستخدام مهار اته في إنجاز عملية التعلم

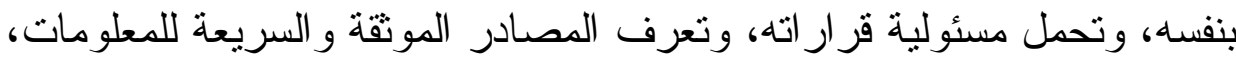

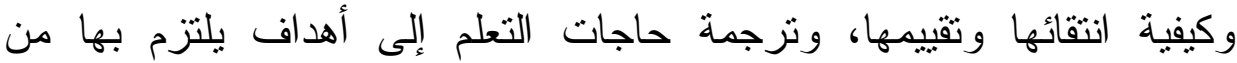
خلال خطط ونشاطات لتحسين الأداء الحالي والإبقاء على الحافز الذاتي

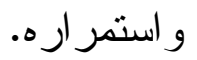

وبالر غم من تعدد نماذج التعلم المنظم ذاتيا، إلا أن النماذج الأولى المفسرة

للتعلم المنظم ذاتيا ركزت فقط على الجانب المعرفي؛ حيث تم تـسليط الــضو ألـاء

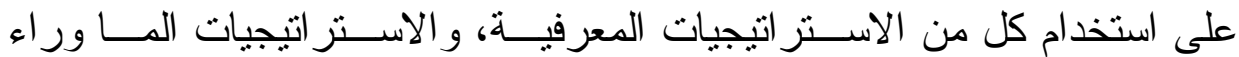
معرفية، و استر اتيجيات إدارة المصادر، منل النموذج الثنالثي لزيمرمان وزملاءه

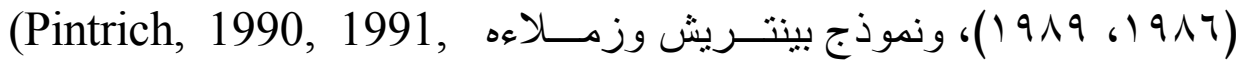
(1994، و النموذج الثلاثي الطبقــات لبوكســارتس و اخــرون Boekaerts, et)

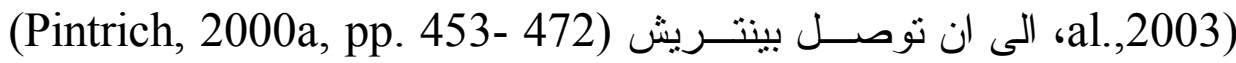

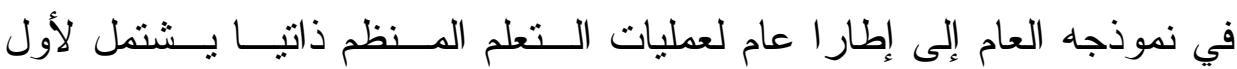

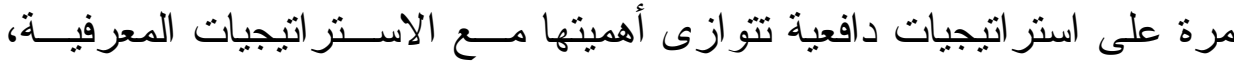

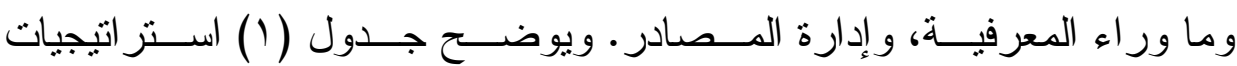

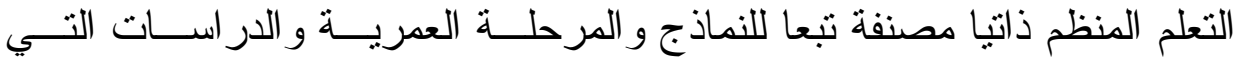
تتاولتها. 
جدول (1)

استر اتيجيات التعلم المنظم ذاتيا مصنفة تبعا للنماذج و المرحلة العمرية

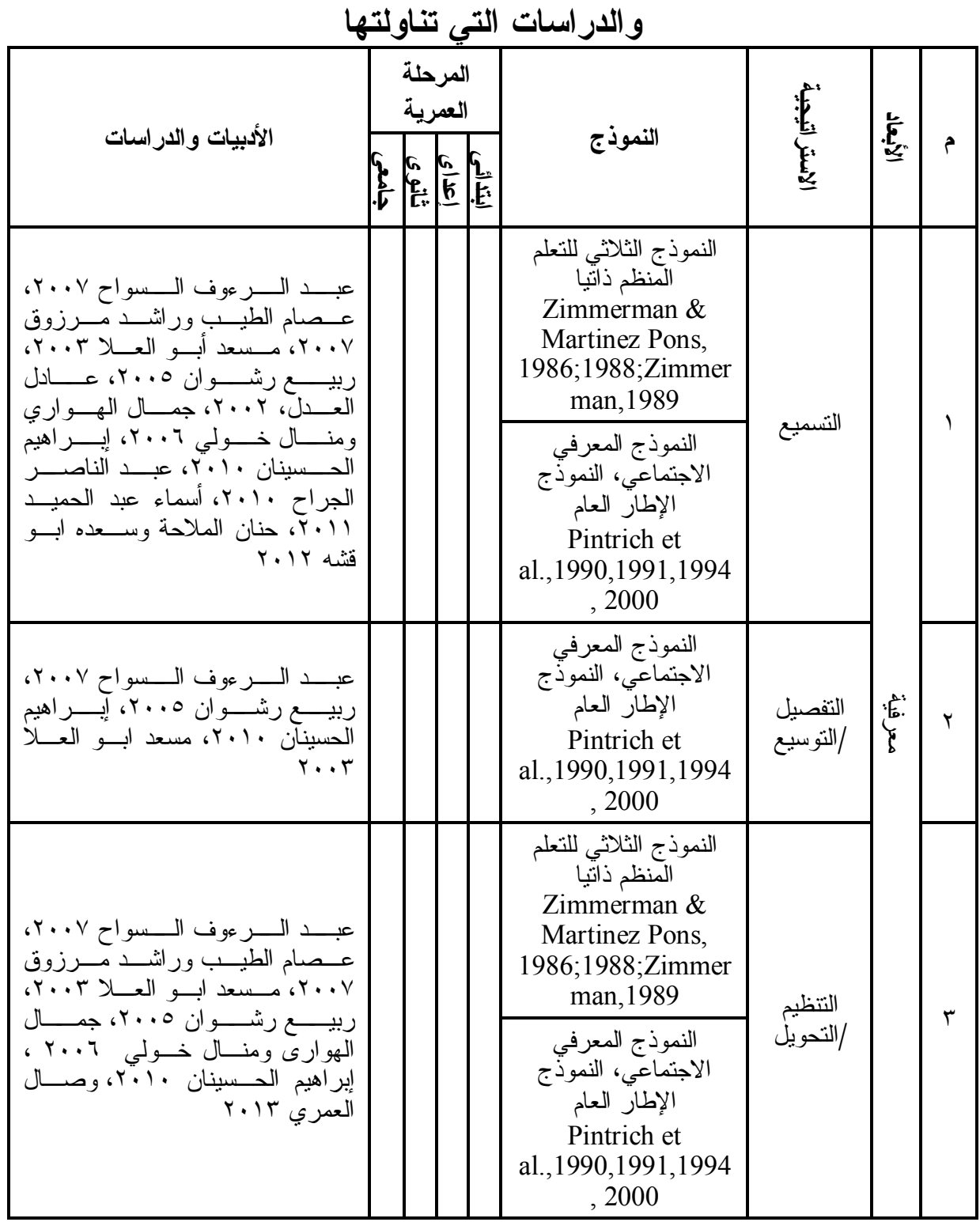




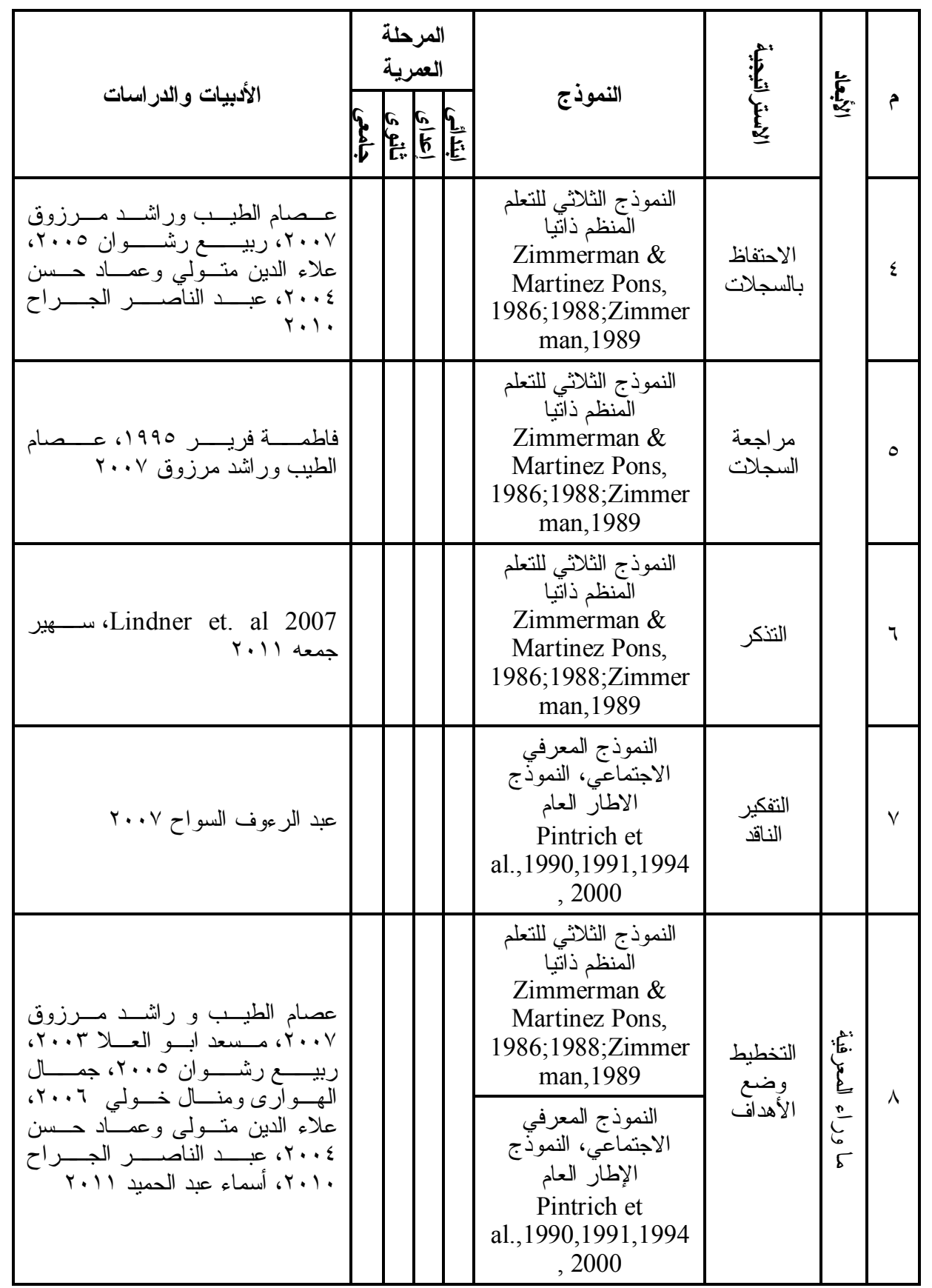




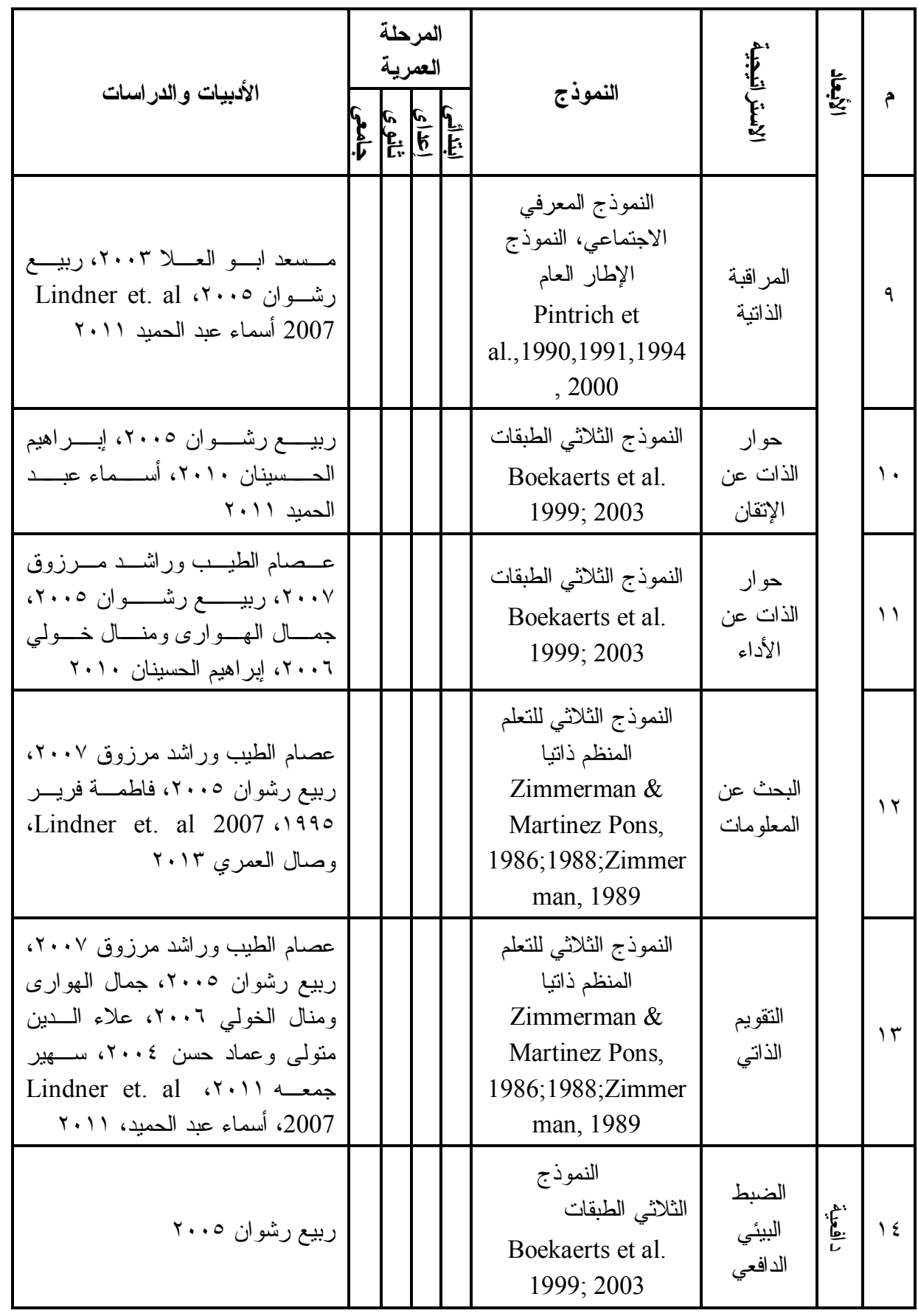




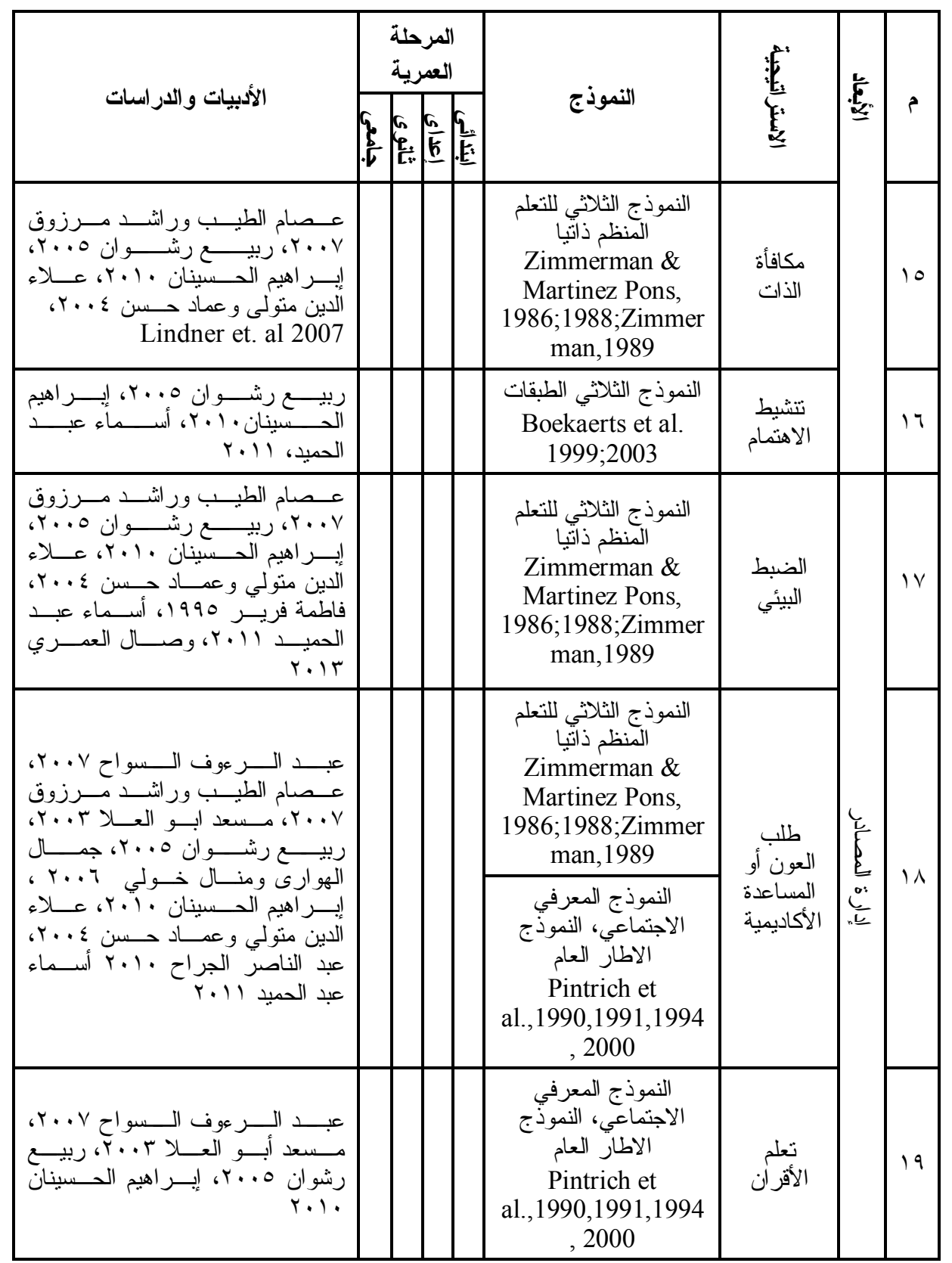




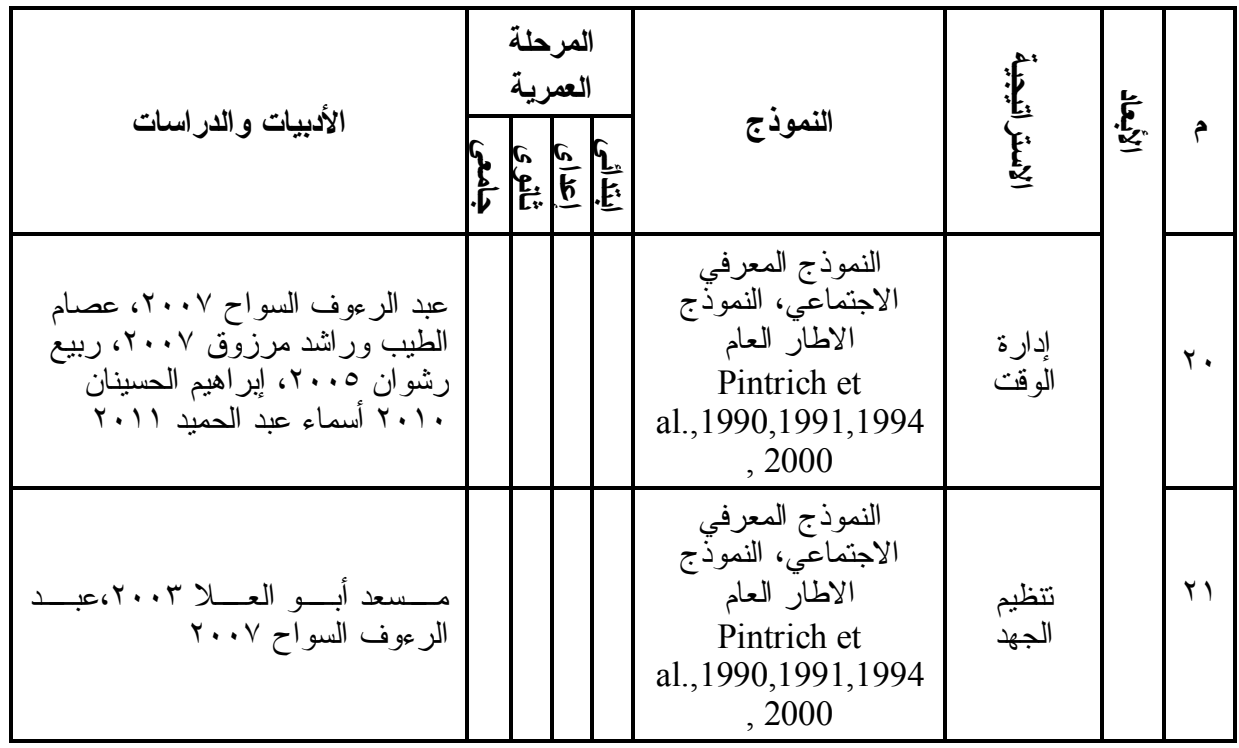

يتضح من جدول (1) ان استراتيجيات التعلم المنظم ذانيا بلغت (Y) (Y)

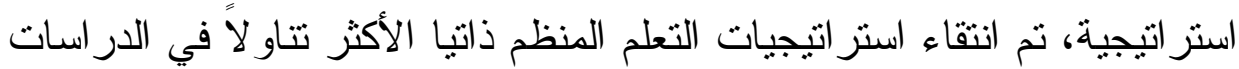

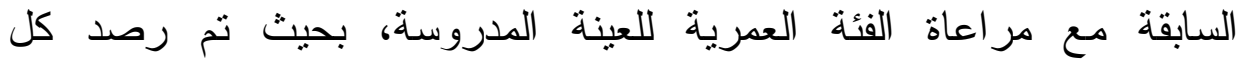
استر اتيجيات التعلم المنظم ذاتيا التي توصلت اليها الدر اسات الحديثة، وتحديد أي من استر اتيجيات التعلم المنظم ذانيا المحددة لكل مرحلة عمرية من أجل تحقيق أهدف الدر اسة الحالية، ويبلور الباحثون تصور هم الخاص باستر اتيجيات التعلم المنظم ذاتيا في الأبعاد الأربعة التالية: الاستر اتيجيات المعرفية ونتشمل:

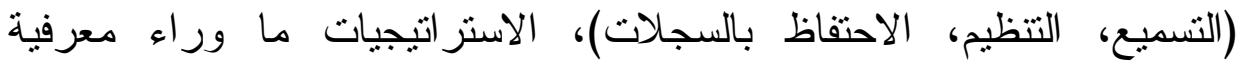

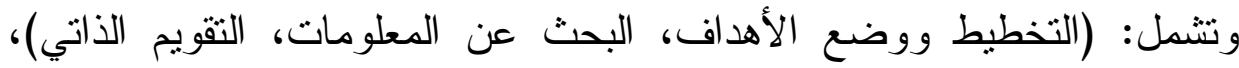
استر اتيجيات إدارة المصادر وتتمل (طلب العون أو المساعدة الأكاديمية، إدارة

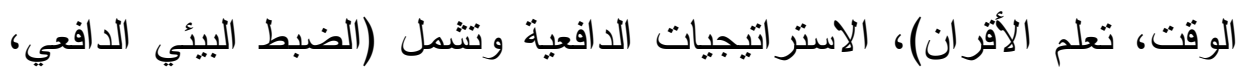

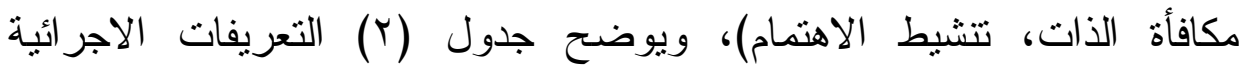
لاستر اتيجيات التعلم المنظم ذاتيا التي تبناها الباحثون. 


\section{جدول (r)}

\begin{tabular}{|c|c|c|c|}
\hline التعريف الإجر ائي & الاستر اتيجية & الأبعاد & 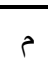 \\
\hline 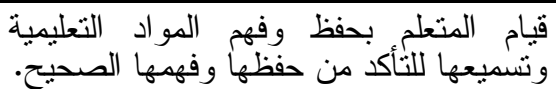 & Rehearsal & المعرفية & 1 \\
\hline 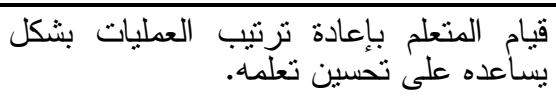 & Organization & & \\
\hline قيام المتعلم بتسجيل الأحداث و النتائج · & $\begin{array}{r}\text { الاحتفاظ بالسجلات } \\
\text { Reviewing Records }\end{array}$ & & \\
\hline قتابعهام الزتعلم بوضع الأهداف التعليمية مع & $\begin{array}{l}\text { • التخطيط وضع الأهداف } \\
\text { Goal Setting \& Planning }\end{array}$ & 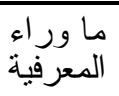 & $r$ \\
\hline 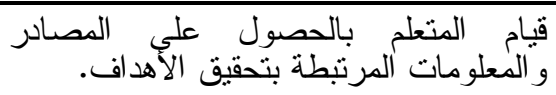 & $\begin{array}{l}\bullet \\
\text { Information Seeking }\end{array}$ & & \\
\hline قبفسام المتعلم باتخاذ اجر اءات لتقويم أدائه & $\begin{array}{l}\text { Self التقويم الذاتي } \\
\text { Evaluation }\end{array}$ & & \\
\hline قالَّمام المتعلم بانتقاء الوقت و الأفر اد المناسبين & 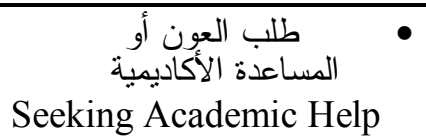 & 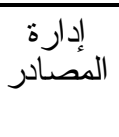 & $r$ \\
\hline 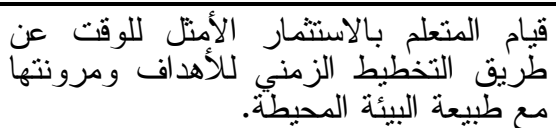 & Time Management & & \\
\hline 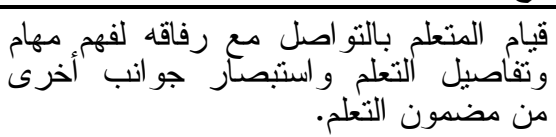 & $\begin{array}{cc}\text { Peers تعلم الأقران } & \text { Learning } \\
& \text { Learning }\end{array}$ & & \\
\hline ثيسير المتعلم بتهيئة بيئة تعلمه ودر استه بدافع مهامه. & $\begin{array}{l}\text { الضبط البيئي الدافعي } \\
\text { Motivational } \\
\text { Environmental } \\
\text { Structuring }\end{array}$ & الدافعية & $\varepsilon$ \\
\hline 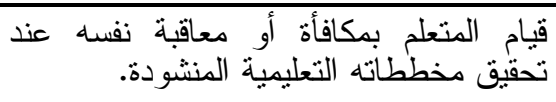 & $\begin{array}{r}\text { مكافأة الذات } \\
\text { Self Consequation }\end{array}$ & & \\
\hline 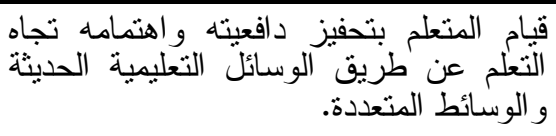 & $\begin{array}{l}\text { تتشيط الاهنمام } \\
\text { Interest } \\
\text { Enhancement }\end{array}$ & & \\
\hline
\end{tabular}




\section{استر اتيجيات التعلم المنظم ذاتيا وعلاقتها بالتحصيل الدراسي:}

كثفت العديد من الدراسات الحديثة في موضوع التعلم المنظم ذاتيا علاقته الارتباطية الوثيقة بالتحصيل الدراسي، فنجد أن الدراسات ركزت فرئ على المتعلم

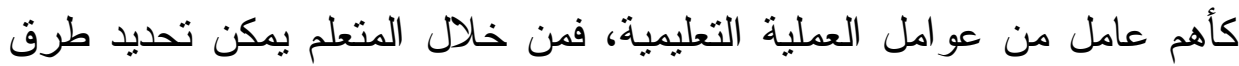

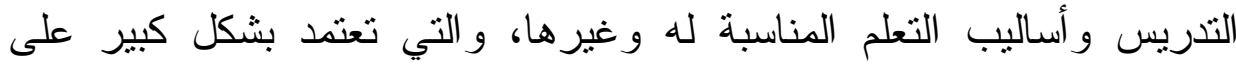

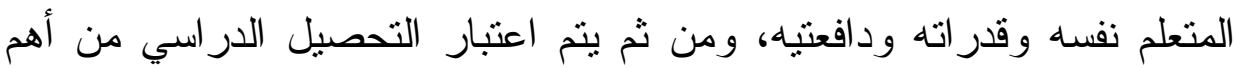

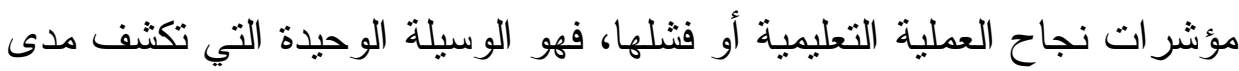
استيعاب المتعلم للمادة المتعلمة وبالتالي فهو الهدف أو الغاية.

وبالرغم من ارتباط مستوى التحصيل الدراسي بالتعلم المنظم ذاتيا، إلا انه هنالك تباينات جوهرية في استخدام استر اتيجيات التعلم المنظم ذاتيا لدى أصحاب المستويات التحصيلية المرتفعة، بما يُّكن هؤلاء الأفر اد من تيسير عملية تعلمهر فئري

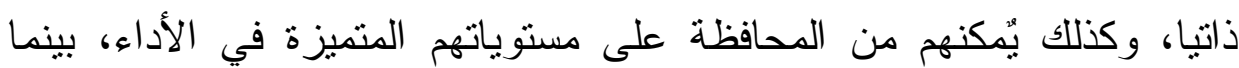

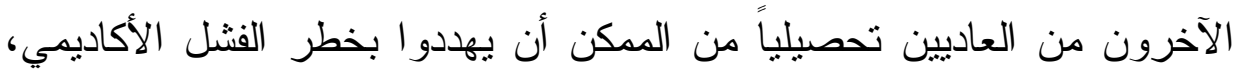

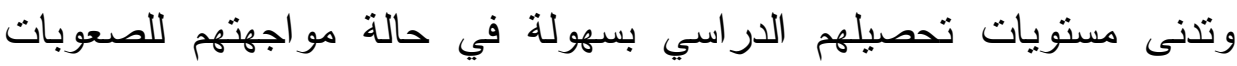
.(Ablard \& Lipschultz, 1998)

طبقا لما سبق يعد التحصيل الدراسي متغير ا تابعا يتم رصده في العديد من الدر اسات التي تتتاول العملية التعليمية، ومن هنا تتاولت العديد من الدراسات التحصيل الدر اسي وعلاقاته المتعددة بالعديد من المتغيرات التربوية و التعليمية، ويعد مصطلح التعلم المنظم ذاتيا من المصطلحات الحديثة نسبيا التي تم تتاولها ومدى ارتباطها بالتحصيل الدراسي كهذف من أهداف العملية التعليمية؛ حيث توجد عدة أدلة جوهرية تؤكد على أن التحصيل الدراسي وجودة النتائج يعتدان بشكل مبانر على الاستعداد و القدرة على التنظيم الذاني للسلوك و العطليات 
المعرفية و الدافعية و البيئية بما يتتاسب مع مطالب الموقف التعليمي بحيث يجمع التعلم المنظم ذاتيا بين كل من هذه العو امل المعرفية و الدافعية.

من الدراسات التي وثقت ارتباطا موجبا بين التحصيل الدراسي واستر اتيجيات التعلم المنظم ذاتيا، دراسة فاطمة فرير (1990 (1)، ودراسة عبد التبات

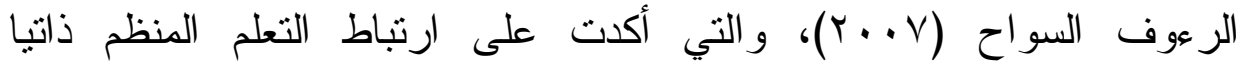
بالتحصيل الدراسي؛ حيث أن المشاركة الفعالة لأصحاب التعلم المنظم ذاتيا تثر

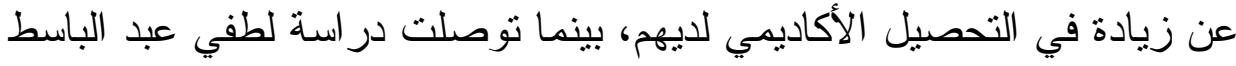

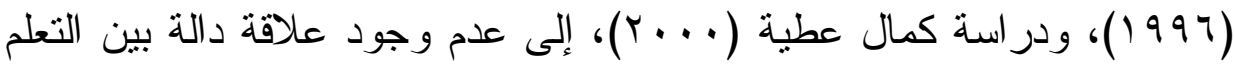
المنظم ذاتيا وبين التحصيل الدراسي. ثاتيا: التحصيل الار اسي

يعتبر التحصيل الدراسي معيار أساسيا ل لمعظم القرارات التربوية المنهجية و التعليمية و الإدارية، فهو معيار أساسي يتم بموجبه تحديد مقدار نقدم

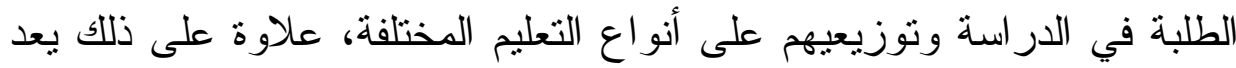
التحصيل في إطاره الواسع (يشمل اكتساب بني المعرفة وعمليات الفكر و أساليب التقكير و اتخاذ القر ار) من العو امل بالغه الأثز في تكوين شخصية الفرد. ويشير فؤاد أبو حطب ( • 99 () للتحصيل الدراسي على أنه "لغة الإنجاز و الإحر از وهو بهذا المعني أكثر اتصالا بالنو اتج المرغوبة للمتعلم، وتحديد هذه

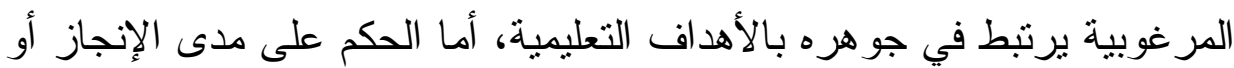
الإحراز فيعتمد في جوهره على التقويم التربوي" (عبد الناصر عبد الوهاب،

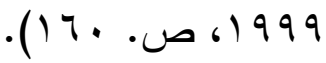
ويعرف التحصيل الدراسي بأنه "الإنجاز في مادة أو مجموعة من المواد

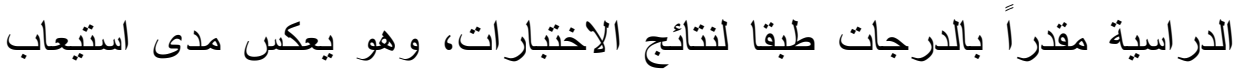


الطلاب لما تعلموه من خبر ات في مادة در اسية أو أكثر (فاطمة فرير،99019

$$
\text { ص. (IVV. n n }
$$

ويرى جلين (Glenn, 2012) أن مفهوم التحصيل الدر اسي يتضمن عدد

من الدلالات التربوية و النفسية التي توضح معنى التحصبل الدراسي فهو :

• معيار أساسي للحكم على قدر ات الطلبة و إمكاناتهم الدراسية في منهاج

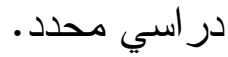

• مؤشر هام لتحديد مستوى المعززات و المزايا و الأدوار الاجتماعية التي

يستحقها الطلبة.

• مصدر رئيسي للتغذية الر اجعة حول مدى تحقيق الأهداف التعليمية. • يحدد مقدار المساعدة الأكاديمية التي يحتاجها الطلبة للتغلب على معوقات

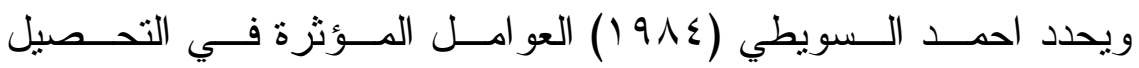

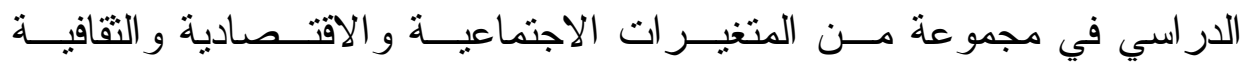

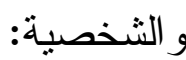

1- المتغير ات البيئية الاجتماعية: وتشمل هذه المتغيرات منغيرات البيئة

$$
\text { البيتية، ومتغير ات المجتمع المحلى. }
$$

ץ- متغير ات الطبقة الاجتماعية: تشير كثير من الدراسات الى أن الطبقة

الاجتماعية التي يأتي منها الطالب نرتبط بتحصيله منذ سنين الدراسة لهيل

$$
\text { الابتدائية. }
$$

r- المتغير ات التربوية و الثخصية: تشمل هذه المتغيرات الجو المدرسي و عو امل شخصية تتعلق بالمتعلم. 


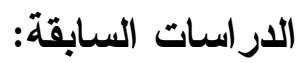

تم تحديد الدراسات ذات الصلة بمتغيرات الدر اسة في محورين أساسين.

أولا: دراسات استهوفت الكثف عن دلاةة العلاقة بين التحصيل الدراسي واستر اتيجيات التعلم المنظم ذاتيا.

في إطار هذه الدراسات هدفت دراسة زيمرمان ومارتتيز - بونز (Zimmerman \& Martinez- pons, 1986) التعلم المنظم ذاتيا و التحصيل الدراسي لدى طلبة المرحلة الإعدادية في مادتي الرياضيات و اللغة الانجليزية، طبق عليهم مقياس استر اتيجيات التعلم المنظم ذاتبا

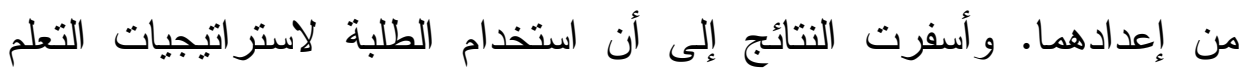
المنظم ذانيا ينبئ بالتحصيل الدراسي للطلبة، حيث فسر التعلم المنظم ذاتيا

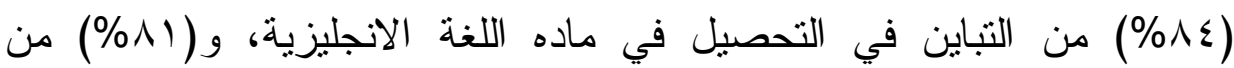

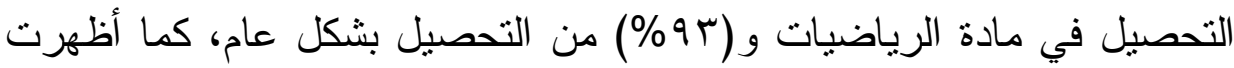

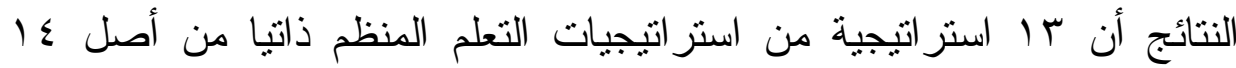
استراتيجية تميز بين الطلبة ذوى التحصيل المرتقع والطلبة ذوى التحصيل المنخفض.

وهدفت دراسة بينتريش وديجورت Pintrich \& DeGroot, وهات (1990إلى الكثف عن العلاقة بين توجه الدافعية و التعلم المنظم ذاتيا، و التحصيل الأكاديمي لدى (VT) طالبا وطالبة من طلاب المرحلة الاعدادية،

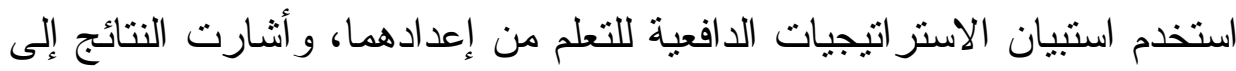
وجود علاقة ارتباطية موجبة بين الكفاءة الذانية، والقيمة الداخلية باعنبارهما مكونين للتعلم المنظم ذاتيا، وبين التحصيل الأكاديمي، كما أظهرت نتائج تحليل 
الانحدار أن التظيم الذاتي، والكفاءة الذاتية، وقلق الاختبار قد عملت باعتبارها متتبئات بالتحصيل الأكاديمي للطلبة، في حين لم يكن للقيمة الداخلية أب تأثير مباشر في التحصيل الأكاديمي للطلبة.

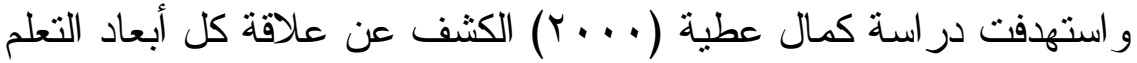
المنظم ذاتيا ودافعية التعلم بالتحصيل الدراسي، وتكونت عينة الدراسة من

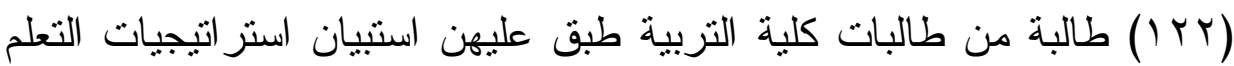
لزيمرمان (Zimmerman, 1988)، وتوصلت نتائج الدراسة إلى عدم وجود

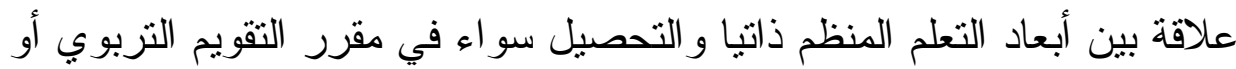
في المعدلات التز اكمية باستثناء دلالة العلاقة بين بعد النطبيق العملي بالتحصيل في مقرر الثقويم التزبوي، وعدم دلالة العلاقة بين بقية أبعاد دافعية التعلم و التحصيل.

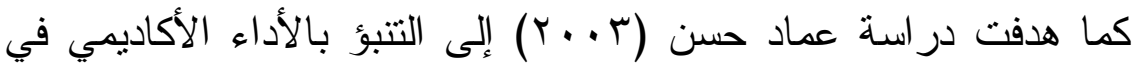

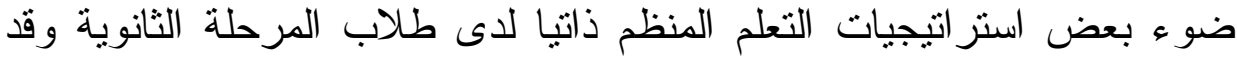

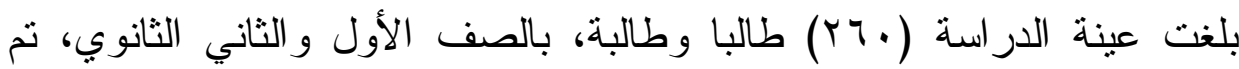

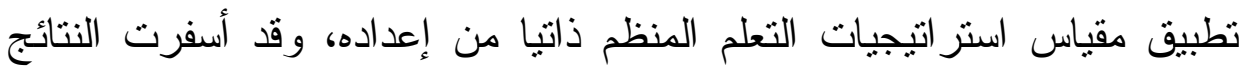
عن وجود فروق دالة في التحصيل الأكاديمي بين المرتفعين و المنخفضين في

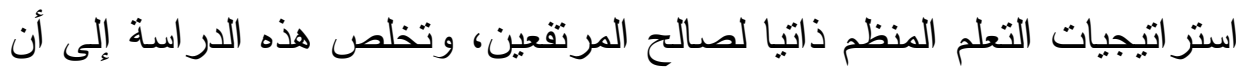

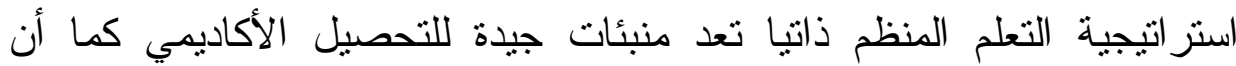
استر اتيجية التتظيم تعد أفضل هذه الاستر اتيجيات.

Nota, Soresi \& ) وتوصلت دراسة نوتا وسوريسى وزيمرمان

(Zimmerman, 2004

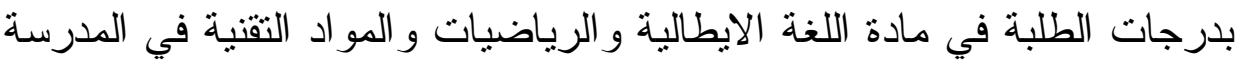


الثانوية، وتتنبأ كذللك بدرجات الطلبة في امتحانات الجامعة، وبدرجاتهم في

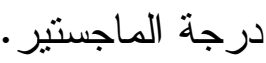

و هدفت دراسة عبد الناصر الجراح (· (ب) إلى الكثف عن

مستوى امتلاك طلبة الجامعة لمكونات التعلم المنظم ذاتيا، وما إذا كانت تلألك

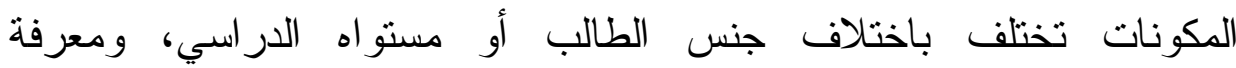
القدرة التتبؤية لمكونات التعلم المنظم ذاتيا بالتحصيل الأكاديمي. وتكونت العينة

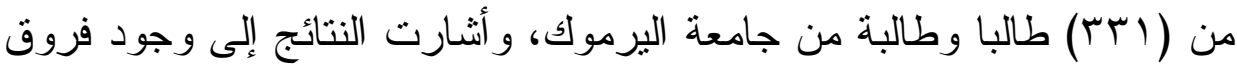
دالة في التحصيل الأكاديمي بين الطلبة مرتفعي التعلم المنظم ذاتيا و الطلبة

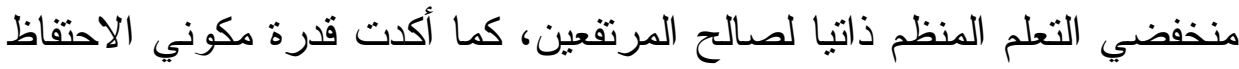

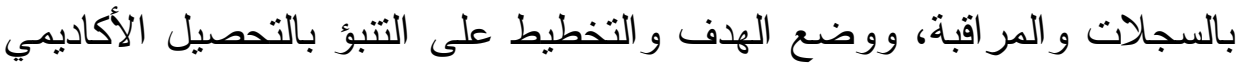
للطلبة.

هدفت دراسة ساجدة طريف (r (ץ) إلى الكثف عن علاقة التعلم

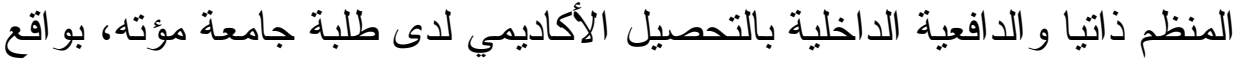

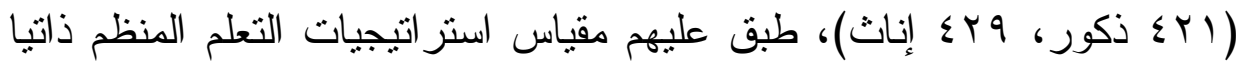

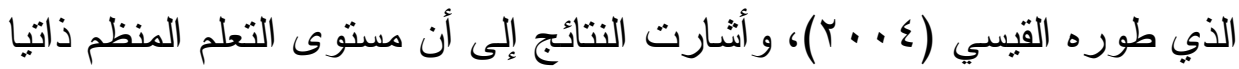
و الدافعية الداخلية لدى طلاب جامعة مؤته جاء منوسطا، ووجود علاقة ايجابية دالة بين متغيري التعلم المنظم ذاتيا و الدافعية الداخلية من ناحية ومتغير التحصيل الدراسي من ناحية أخرى، والى إمكانية التتبؤ بالتحصيل الدراسي من خلال متغيري التعلم المنظم ذانيا و الدافعية الداخلية. هدفت دراسة أحمد الثريم وزياد اللالا (10 ب) إلى الكثف عن مدى امتلاك طلبة قسم التربية الخاصة لمكونات التعلم المنظم ذاتبا و الدافعية العقلية، و العلاقة بينهما، و القدرة التنبؤية لكل منهما بالتحصيل الأكاديمي، وتكونت العينة 


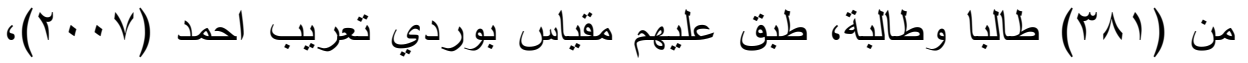

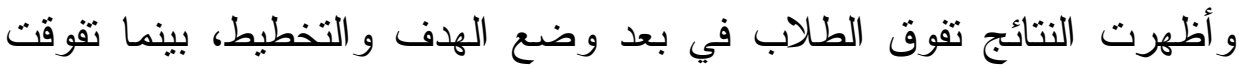
الطالبات في بعد طلب المساعدة الاجتماعية، ووجود علاقة موجبة دالة بين

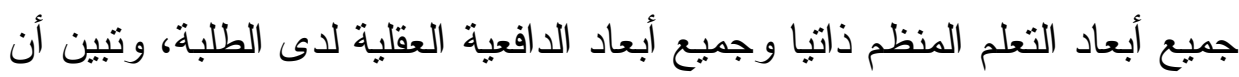

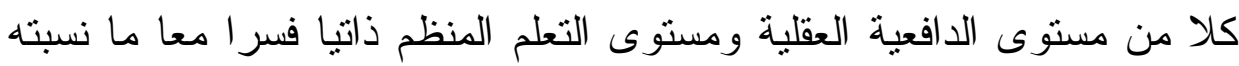
(9 (\%) من التباين في المعدل التزر اكمي للطالب. تعقيب على دراسات المحور الاول:

من حيث الأهداف: اجتمعت العديد من الدراسات في هدف تحديد طبيعة

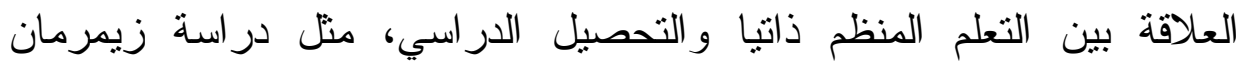
ومارتينيز - بونز (Yimmerman \& Martinez- pons, 1986)، ودراسة

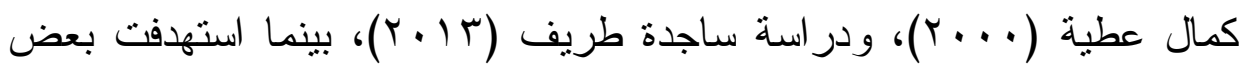
الدراسات الاخرى التتبؤ بالتحصيل الدراسي من خلال استراتيجيات التعلم

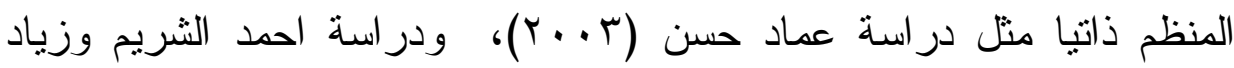

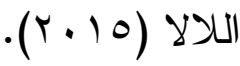

من حيث العينة: تناولت الدراسات عينات مختلفة من حيث الصف الدر اسي؛ حيث تتاولت در اسة زيمرمان ومارنتيز - بونز عimmerman \&

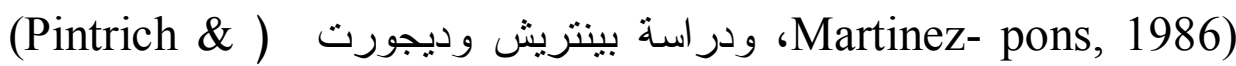

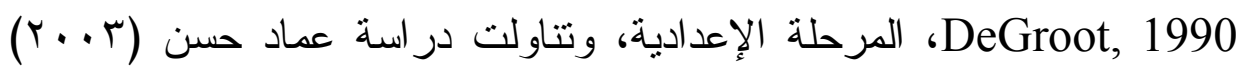

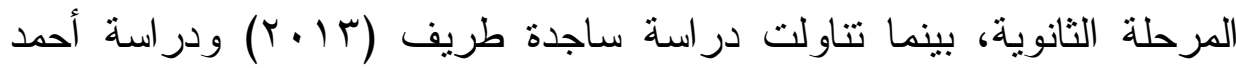
الثريم وزياد اللالا (10 ب ب المرحلة الجامعية. من حيث الأدوات: استخدمت دراسة زيمرمان ومارنتيز - بونز (Zimmerman \& Martinez- pons, 1986)، ودراسة كمال عطية 


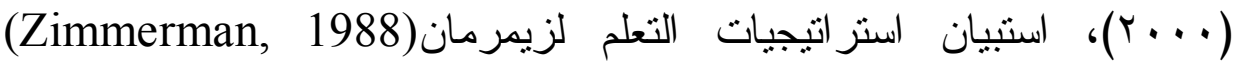
أما دراسة بينتريش وديجورت (Pintrich \& DeGroot, 1990) ودراسة

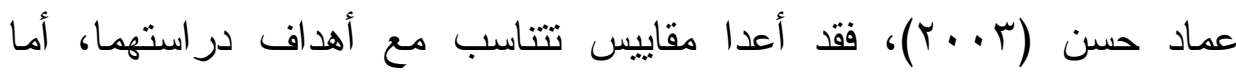

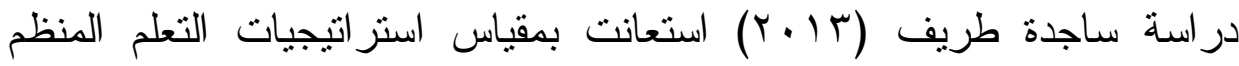

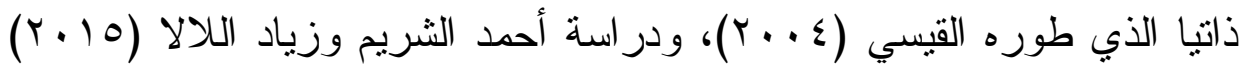

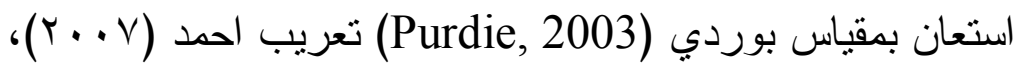
من حيث النتائج: تباينت نتائج الدراسات التي تتاولت علاقة التعلم المنظم

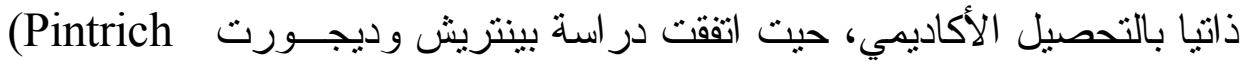

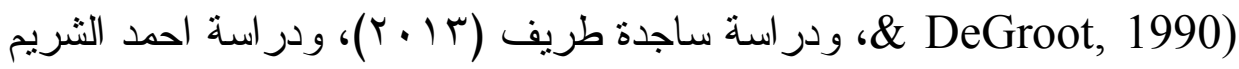
وزياد اللالا (10 (10) على وجود علاقة ارتباطية موجبة بين التحصيل الدراسي

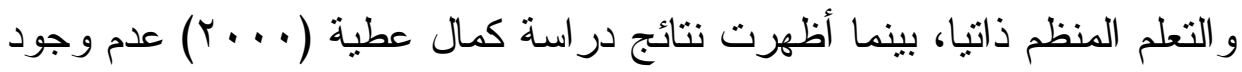
علاقة ارتباطية بين التحصيل الدراسي و التعلم المنظم ذاتيا، كما توصلت نتسائج

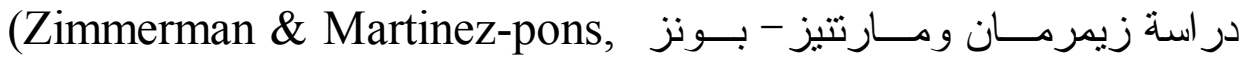

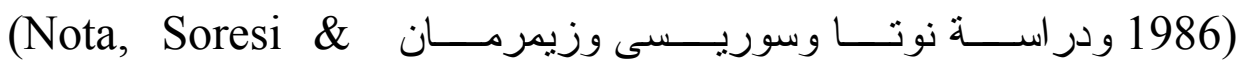

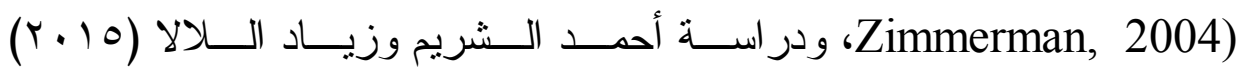
إلى إمكانية التتبؤ بالتحصيل الدراسي بمعلوميــة اســتر اتيجيات الــتعلم المــنظم ذاتبا.

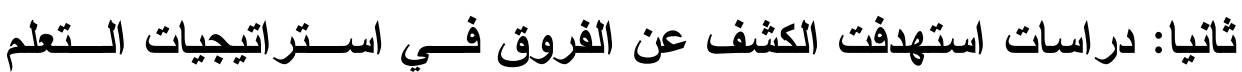
المنظم ذاتيا وفقا للبيئة الثقافية.

قامت بوردي (Purdie, 1994) بدر اسة بعنوان "ما هي أفكــار الطــلاب

حول المتعلم؟ وكيف يفعلون ذلك؟ مقارنة عبر الثقافة"، حيث هدفت الدراسة إلى بلى

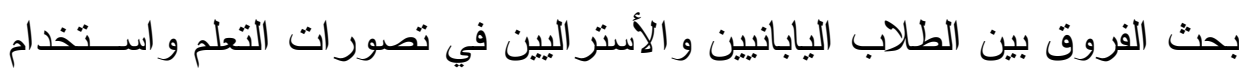




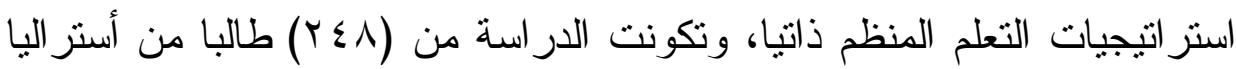

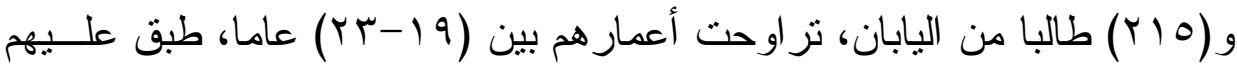

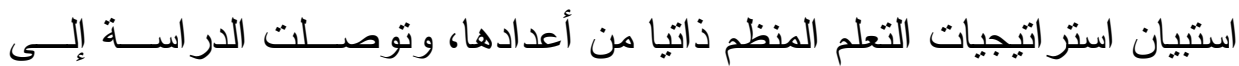
تفوق الطلاب الأستر اليين عن اليابانيين في استخدام استر اتيجيات التعلم المـنظم ذاتبا.

(Chye, Walker \& Smith, أنشارت در اسة تشاى وويلكـر وســيث

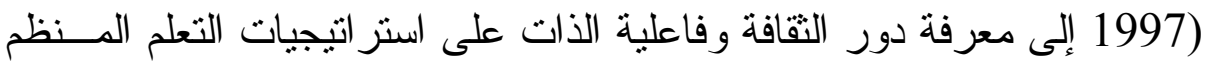

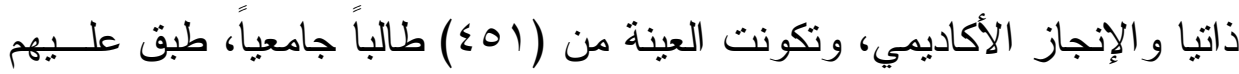

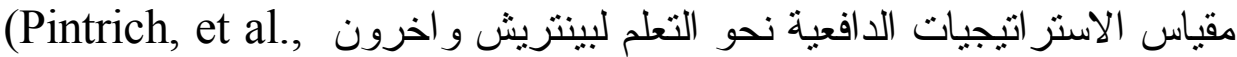

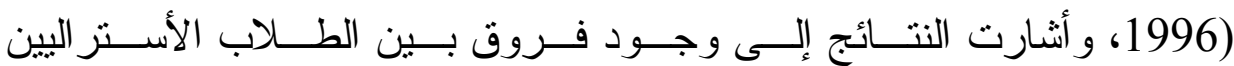
و السنغافوريين الدارسين في سنغافورة و السنغافوريين الدارسين في أستر اليا فـي لـي السي

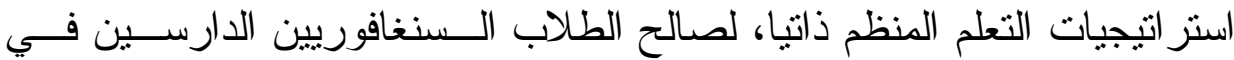

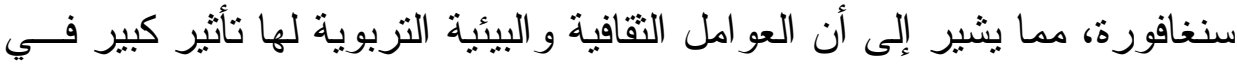
سلوك استخدام استر اتيجيات التعلم المنظم ذاتيا لاى الطلاب. كما هدفت در اسة بلت (Pelt, 2003) إلى الكثف عن دلالة العلاقة بــين

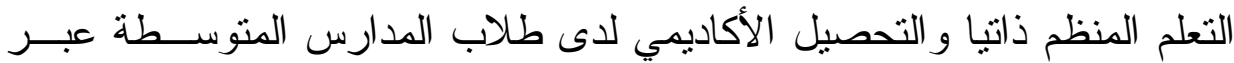

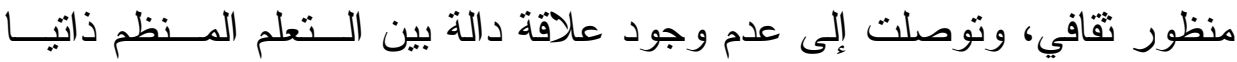
و التحصيل الأكاديمي، ولم يتضح وجود فروق دالة فــي اســتر اتيجيات الــتعلم

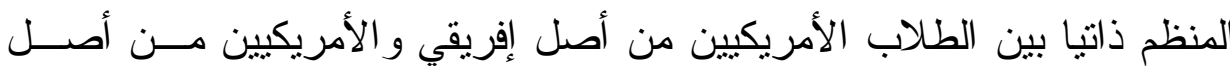

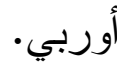

وفي در سة أجر اها سوى-كو (Sui-Chu, 2004) استهدفت بيان العلاقة بين التحصيل الأكاديمي و التعلم المنظم ذاتيا لدى عينة من الطلبة بلغ عمر هم 10

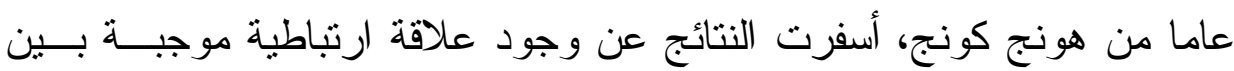


التعلم المنظم ذاتيا وبين التحصيل الأكاديمي في مـــواد القـــراءة و الرياضــيات

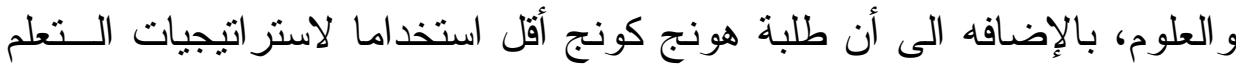
المنظم ذاتيا من باقي طلبة الدول الأخرى.

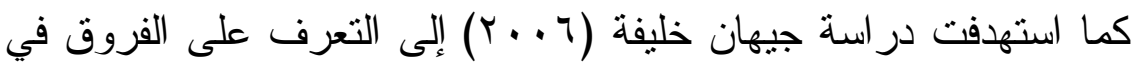

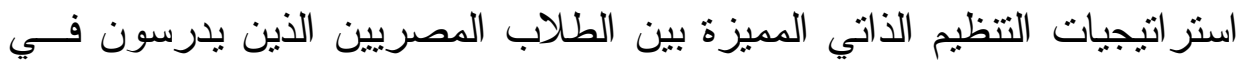

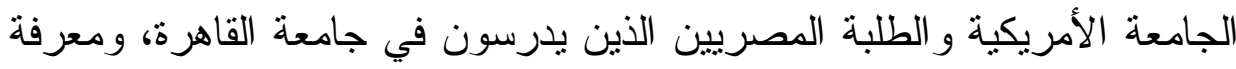

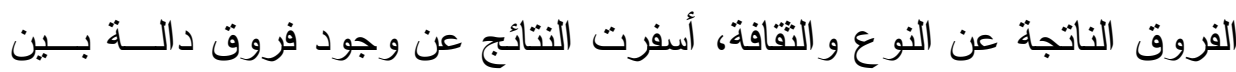

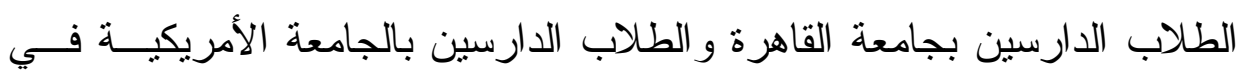
مقياس استر اتيجيات التعلم المنظم ذاتيا.

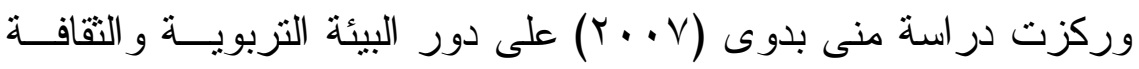

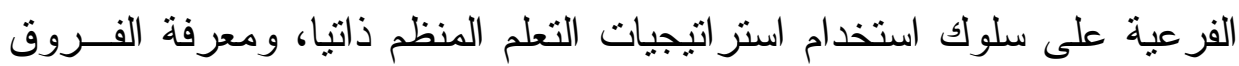

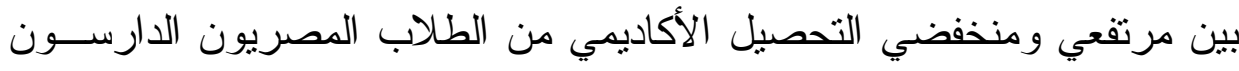

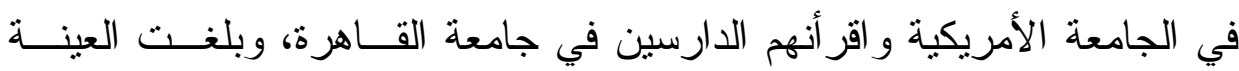

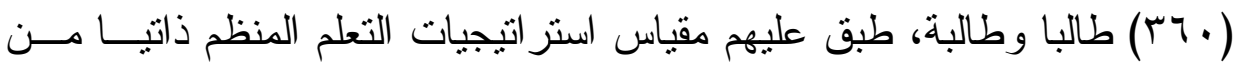

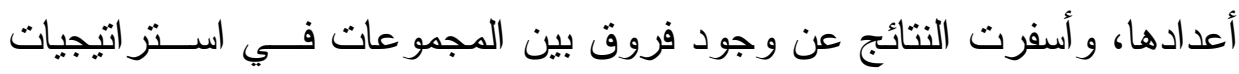

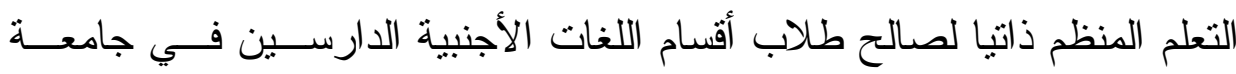

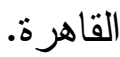
وتتاولت در اسة وليد السيد (9 . . ب) الكثف عن دلالة الفروق بين طلاب

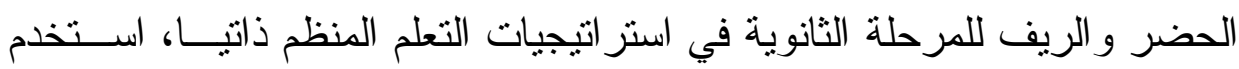

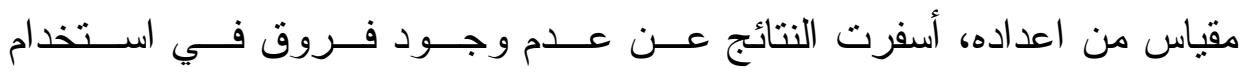

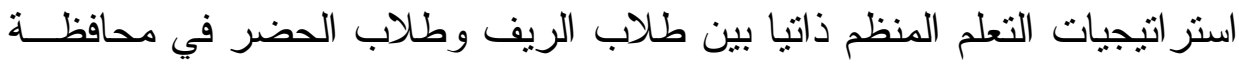
الزقازيق. 


\section{تعقيب على دراسات المحور الثاني:}

من حيث الأهداف: اجتمعت العديد من الدراسات في الكثف عن دلالة

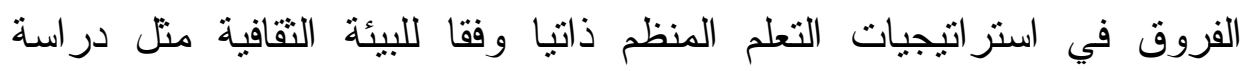
بوردي (Purdie, 1994) ودر اسة تنتاى وويلكر وسميث \& Chye, Walker)

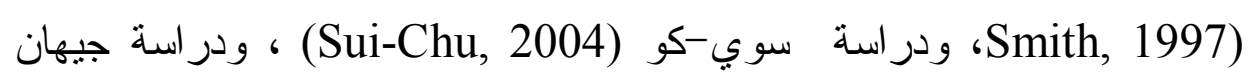

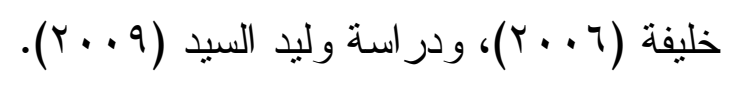

من حيث العينة: اختلفت عينات دراسات المحور الثاني باختلاف الطبيعة

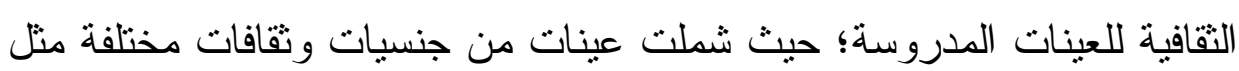

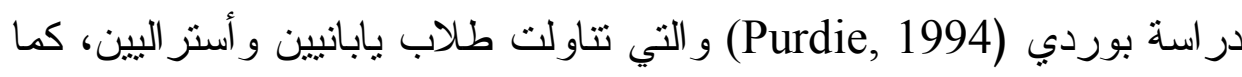

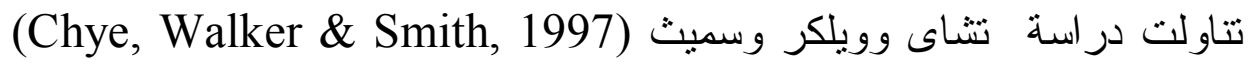
طلاب أستراليين وسنغافوريين، كما اختلفت طبيعة العينات وفقا للشرائح

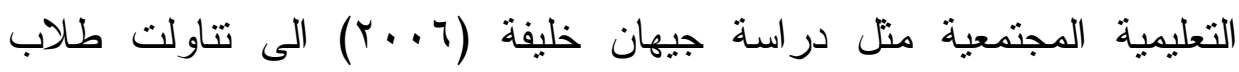

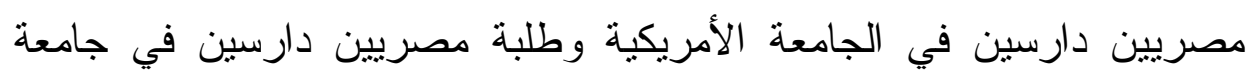

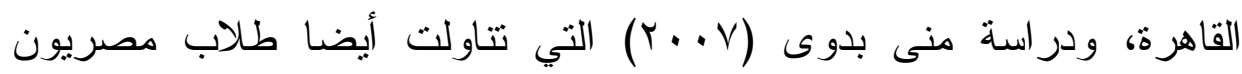

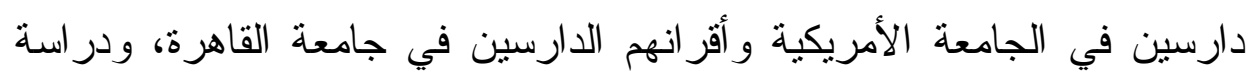

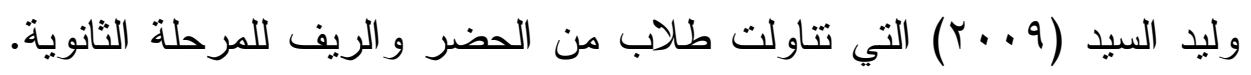

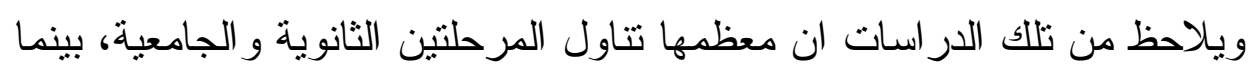
لم تتتاول أي دراسة عينات من مراحل تعليمية مختلفة كما هو حال الدراسة ولئة الحالية.

من حيث الأدوات: استعانت دراسة بوردي (Yurdie, 1994)، ودر اسة

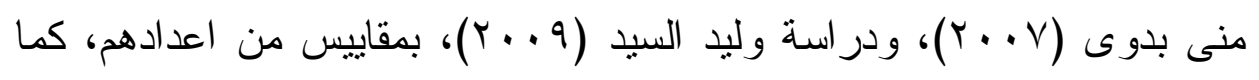
هو الحال في الدراسة الحالية، بينما اعتمدت دراسة ولثن تثناى وويلكر وسميث 
(Chye, Walker \& Smith, 1997) ،(Pintrich, et al., 1996)

من حيث النتائج: أكدت معظم الدراسات على إسهام البيئة الثقافية في استخدام استر اتيجيات التعلم المنظم ذاتيا متل دراسة بوردي (Purdie, 1994) ، ودراسة تثاى وويلكر وسميث (Chye, Walker \& Smith, 1997)

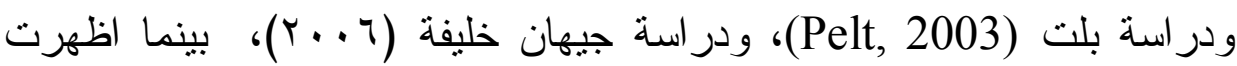
در اسة وليد السيد (9 . . ץ) عدم وجود فروق دالة بين طلاب الحضر وطلاب الريف في استر اتيجيات التعلم المنظم ذاتيا.

يتضح من العرض السابق وبحوث المحورين السابقين الدور المهم لاستر اتيجيات التعلم المنظم ذاتيا في عملية التعلم و التحصيل الدراسي، ومن هنا تهدف الدر اسة الى تحديد درجة امتلاك طلاب مر احل التعليم العام استر اتيجيات التعلم المنظم ذاتيا، و إلى أي مدى تختلف استر اتيجيات التعلم المنظم ذاتيا وفقا لمتغير البيئة الثقافية (الحضر و الريف) والى مدئ فروض الار اسة:

في ضوء الإطار النظري و الدراسات، يمكن صياغة الفروض كالتالي: 1-يستخدم طلاب كل مرحلة من مراحل التعليم العام استر اتيجيات التعلم

$$
\text { البنظم ذاتيا بدرجة متوسطة. }
$$

r-ترنبط استر اتيجيات التعلم المنظم ذاتيا بالتحصيل الدر اسي لدى طلاب كل بلاعل مرحلة من مر احل التعليم العام (ابتدائي، إعدادي، ثانوي).

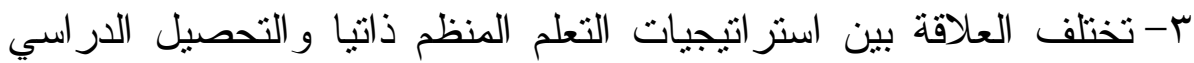

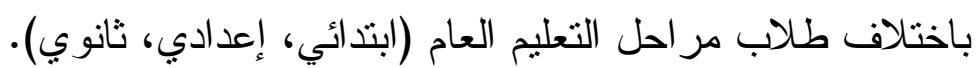


ع- تختلف استر اتيجيات التعلم المنظم ذاتيا وفقا لمتغير البيئة الثقافية (الحضر

$$
\text { و الريف). }
$$

0- تختلف العلاقة بين استر اتيجيات التعلم المنظم ذاتيا و التحصيل الدراسي

$$
\text { باختلاف البيئة الثقافية (الحضر و الريف). }
$$

\section{مجتمع الار اسة:}

يتكون من (rسז,ء؟) طالبا وطالبة وفقا لبيان أعداد الطلبة للمراحل

الثناث (ابتدائي، إعدادي، ثانوي ) الصادر من مركز المعلومات ودعم إتخاذ

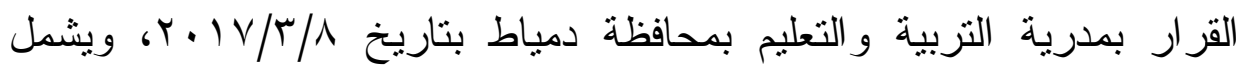

$$
\text { (ذكور ، إناث)، ويضم مدينة دمياط وضو احيها. }
$$

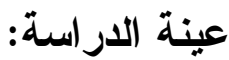

تكونت عينة الدراسة في صورتها النهائية من (7 (1) طالبا وطالبة منهم،

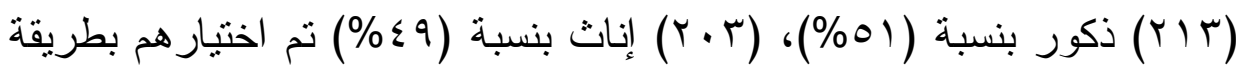

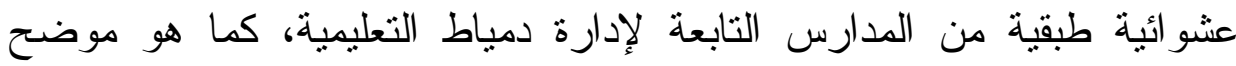
بجدول (r). 


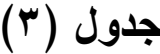

أعداد وتوزيع العينة الأساسية وفقا لمتغيرات الاراسة

\begin{tabular}{|c|c|c|c|c|c|c|c|c|c|c|c|c|c|}
\hline \multirow{3}{*}{ 京 } & \multicolumn{4}{|c|}{ ثانوي } & \multicolumn{4}{|c|}{ إعدادي } & \multicolumn{4}{|c|}{ ابتدائي } & \multirow{2}{*}{ الصف } \\
\hline & \multicolumn{2}{|c|}{ الثاني } & \multicolumn{2}{|c|}{ الأول } & \multicolumn{2}{|c|}{ الثاني } & \multicolumn{2}{|c|}{ الأول } & \multicolumn{2}{|c|}{ الخامس } & \multicolumn{2}{|c|}{ الرابع } & \\
\hline & ريف & حضر & ريف & حضر & ريف & حضر & ريف & حضر & ريف & حضر & ريف & حضر & البيئة \\
\hline rir & $r$. & 11 & r. & ir & rr & ir & ro & 17 & rr & $1 \leqslant$ & r) & 17 & ذكور \\
\hline$r \cdot r$ & $r$. & $1 \varepsilon$ & iv & ir & $r$. & Ir & צו & $1 \varepsilon$ & 11 & ir & r. & 17 & إناث \\
\hline \multirow{2}{*}{ «17 } & $\varepsilon$. & ro & rv & r & $\varepsilon r$ & rq & 01 & $r$. & $\varepsilon$. & r & ؛ & rr & \multirow{2}{*}{ المجموع } \\
\hline & \multicolumn{4}{|c|}{ (\%rI) IKA } & \multicolumn{4}{|c|}{ (\%ץч) } & \multicolumn{4}{|c|}{$(\% r r)$} & \\
\hline
\end{tabular}

وللتأكد من تجانس عينة الدراسة تم إيجاد الفروق تبعا لمتغيري الجنس و الصف الدر اسي في استز اتيجيات التعلم المنظم ذاتيا، كما يوضح جدول (ع) (ع) الفروق بين متوسطي درجات ذكور و إناث المرحلة الابتدائية في استر اتيجيات التعلم المنظم ذاتيا.

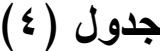

دلالة الفروق بين متوسطي درجات ذكور وإناث المرحلة الابتدائية في

\begin{tabular}{|c|c|c|c|c|c|c|c|}
\hline \multirow{2}{*}{ الدلالة } & \multirow{2}{*}{ قيمة "ت" } & \multicolumn{2}{|c|}{ إناث ن= 79} & \multicolumn{2}{|c|}{ ذكور ن= = } & \multirow{2}{*}{ الاستر اتيجيات } & \multirow{2}{*}{ p } \\
\hline & & $\varepsilon$ & p & $\varepsilon$ & 5 & & \\
\hline غير دالة & $\cdot, 91$ & r, YO & $11, \wedge$. & $r, \cdot V$ & 11,174 & التسميع & 1 \\
\hline غير دالة & $\cdot, r \cdot$ & $r, \cdot 9$ & $11, \leq r$ & $r, \cdot \Lambda$ & $11,0 \varepsilon$ & التنظيم & $r$ \\
\hline غير دالة & $\cdot, \wedge \mu$ & $r, 10$ & $11, \cdot v$ & $r, \ldots$ & $1 \cdot, \vee \wedge$ & الاحتفاظ بالسجلات & r \\
\hline غير دالة & $\cdot, r T$ & $r, 70$ & $11, \wedge \mathrm{V}$ & $r, 11$ & 11,91 & التخطبط ووضع الأهداف & $\varepsilon$ \\
\hline غير دالة & $\cdot, \Gamma \varepsilon$ & $r, r \varepsilon$ & $11, Y \leq$ & $r, \ldots$ & 11,14 & البحث عن المعلومات & 0 \\
\hline غير دالة & $\cdot, \mathrm{VT}$ & $r, \Gamma \wedge$ & 14,10 & $r, Y T$ & $11, \wedge 7$ & التقويم الذاتي & 7 \\
\hline$\cdot, \cdot 1$ & $r, 19$ & $r, 1$. & $1 \cdot, \cdot 7$ & $1, \wedge r$ & $9, r r$ & طلب العون الأكاديمي & $\mathrm{V}$ \\
\hline غير دالة & $\cdot, V Y$ & $r, r$. & 11,04 & $r, 19$ & $11, \wedge$. & إدارة الوقت & $\Lambda$ \\
\hline غير دالة & 1,04 & $r, r_{1}$ & $1 \cdot, 77$ & 1,91 & $1 \cdot, 1 \cdot$ & تعلم الأقران & 9 \\
\hline غير دالة & $\cdot, r V$ & $r, Y \wedge$ & $11, \leq 0$ & $r, r)$ & 11,07 & الضبط البيئي الدافعي & 1. \\
\hline غير دالة & $\cdot, \mathrm{V}$ & $r, r V$ & $1 \cdot, 0 \mathrm{~V}$ & r, ro & $1 \cdot, r \wedge$ & مكافأة الذات & 11 \\
\hline غير دالة & $\cdot, 9 \varepsilon$ & $1, V Y$ & $11, \mathrm{VV}$ & $r, r T$ & $1 \cdot, V r$ & تتشبط الاهتمام & IT \\
\hline غير دالة &., $0 \mathrm{~V}$ & $I V, r$ & $1 \Gamma \varepsilon, 7$ & $1 \pi, 0$ & 1 & الدرجة الكلية & 11 \\
\hline
\end{tabular}


يتضح من جدول (ع) عدم وجود فروق دالة بين منوسطي درجات ذكور

و إناث المرحلة الابتدائية في استر اتيجيات التعلم المنظم ذاتيا، عدا استر اتيجية

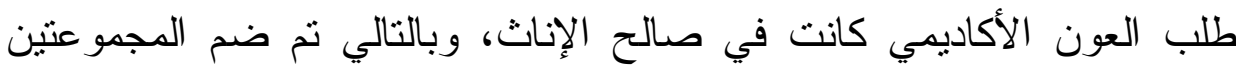

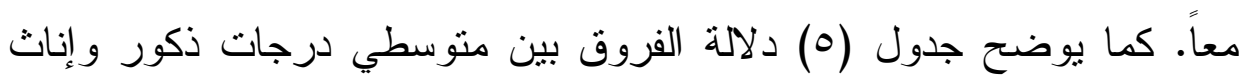
المرحلة الإعدادية في استر اتيجيات التعلم المنظم ذاتيا:

\section{جدول (0)}

دلالة الفروق بين متوسطي درجات ذكور و إناث المرحلة الإعدادية في

\begin{tabular}{|c|c|c|c|c|c|c|c|}
\hline \multirow{2}{*}{ مستلوي } & \multirow{2}{*}{ "تيمة } & \multicolumn{2}{|c|}{ VY = إناث ن } & \multicolumn{2}{|c|}{ ذكور ن= vi } & \multirow{2}{*}{ الاستر اتيجيات } & \multirow{2}{*}{ b } \\
\hline & & $\varepsilon$ & م & $\varepsilon$ & م & & \\
\hline غير دالة & ד & $\overline{r, T r}$ & $1 \cdot, \mathrm{VA}$ & $r, 1 \leqslant$ & $1 \cdot, 71$ & التسميع & 1 \\
\hline غير دالة & $\cdot, r$ & $r, I T$ & $11, r$. & $r, 1 \wedge$ & $11, r V$ & التنظيم & $r$ \\
\hline غير دالة & $\cdot, 70$ & $r, 10$ & $11, .7$ & $r, \cdot \wedge$ & $1 \cdot, \wedge \varepsilon$ & الاحتفاظ بالسجلات & $r$ \\
\hline غير دالة & $\cdot, \wedge 9$ & $\overline{r, Y V}$ & $11, \lambda \mathrm{V}$ & r,r & 11,04 & التخطيط ووضع الأهداف & $\varepsilon$ \\
\hline غير دالة & $\cdot, V Y$ & 1,79 & $11, .9$ & $r, 1$. & 11,11 & البحث عن المعلومات & $\circ$ \\
\hline غير دالة & 1,04 & r, YO & $I_{1}, \ldots$ & $r, I T$ & $11, \varepsilon \varepsilon$ & التقويم الذاتي & 7 \\
\hline غير دالة & $\cdot, 19$ & 1,7 & $1 \cdot, \Lambda Y$ & 1,97 & $1 \cdot, 9$. & طلب العون الأكاديمي & $\bar{v}$ \\
\hline$\cdot, \cdot 1$ & $r, r V$ & $r, \cdot 1$ & $11, \leqslant 7$ & $1, v 1$ & $1 \cdot, V T$ & إدارة الوقت & $\wedge$ \\
\hline غير دالة & $\cdot, 91$ & $r, r_{0}$ & $1 \cdot, 90$ & $r, .9$ & $1 \cdot, \pi r$ & تعلم الأقران & 9 \\
\hline غير دالة & $\cdot, \wedge$. & $r, r$ & $11,0 \mathrm{~V}$ & $r, \cdot r$ & $11, Y \wedge$ & الضبط البيئي الدافعي & 1. \\
\hline غير دالة & $\cdot, 1 T$ & $r, 19$ & $1 \cdot, \wedge$. & $r, \cdot 1$ & $1 \cdot, \sqrt{ } 4$ & مكافأة الذات & 11 \\
\hline غير دالة & $\cdot, \lambda \varepsilon$ & $r, r$. & $11, r$. & $r, r$. & $1 \cdot, 19$ & تتشيط الاهتمام & ir \\
\hline غير دالة & 1,1 . & $1 \leqslant, 9$ & $1 T \varepsilon, \wedge$ & $10, Y$ & $\mid r T, 1$ & الدرجة الكلية & 14 \\
\hline
\end{tabular}

يتضح من جدول (0) عدم وجود فروق دالة بين منوسطي درجات ذكور و إناث المرحلة الإعدادية في استراتيجيات التعلم المنظم ذاتيا، عدا استر اتيجية

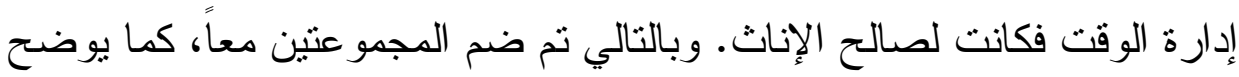
جدول (؟) دلالة الفروق بين متوسطي درجات ذكور و إناث المرحلة الثانوية في استز اتيجيات التعلم المنظم ذاتيا: 
جدول (7)

دلالة الفروق بين متوسطي درجات ذكور وإناث المرحلة الثانوية في

\begin{tabular}{|c|c|c|c|c|c|c|c|}
\hline \multirow{2}{*}{ مستوية } & \multirow{2}{*}{ "قيمة } & \multicolumn{2}{|c|}{ إناث ن= } & \multicolumn{2}{|c|}{ ذكور ن= } & \multirow{2}{*}{ الاستر اتيجيات } & \multirow{2}{*}{ r } \\
\hline & & $\varepsilon$ & م & $\varepsilon$ & م & & \\
\hline غير دالة & $1,1 \mathrm{~V}$ & $r, \cdot \Lambda$ & $1 \cdot, V Y$ & $1, \wedge 7$ & $\mid \cdot, r$ & التسميع & 1 \\
\hline غير دالة & $\cdot, r \wedge$ & T,rY & $1 \cdot, 19$ & $r, 10$ & $1 \cdot, 11$ & التنظيم & r \\
\hline غير دالة & 1,17 & 1,99 & $1 \cdot, v \cdot$ & 1,90 & $1 \cdot, \cdot V$ & الاحتفاظ بالسجلات & $r$ \\
\hline$\cdot, \cdot 1$ & $r, \ldots$ & $r, I Y$ & 11,77 & 1,99 & $1 \cdot, 00$ & التخطيط ووضع الأهداف & $\varepsilon$ \\
\hline غير دالة & $\cdot, 1 \vee 9$ & $1,9 \varepsilon$ & $1 \cdot, 77$ & $1,7 Y$ & $1 \cdot, \leqslant 1$ & البحث عن المعلومات & 0 \\
\hline غير دالة & $\cdot, 91$ & $Y, Y T$ & $11, Y_{1}$ & $1,9 V$ & $1 \cdot, \wedge \mathrm{V}$ & التقويم الذاتي & 7 \\
\hline غير دالة & $1, r \cdot$ & $r, \cdot r$ & $\mid \cdot, \leqslant 1$ & $1, \leqslant 7$ & $1 \cdot, \cdot r$ & طلب العون الأكاديمي & $\mathrm{V}$ \\
\hline$\cdot, \cdot 1$ & $r, \wedge r$ & $1,9$. & $11, r 0$ & $1,7 \varepsilon$ & I.,T & إدارة الوقت & $\Lambda$ \\
\hline غير دالة & $\cdot, 71$ & 1,10 & $1 \cdot, 0 \leqslant$ & 1,90 & $1 \cdot, \Gamma$ & تعلم الآقر ان & 9 \\
\hline$\cdot, \cdot 1$ & $r, r \wedge$ & $r, 1 \Lambda$ & $11, Y \mathrm{~V}$ & $Y, \cdot Y$ & $1 \cdot, \Gamma V$ & الضبط البيئي الدافعي & 1. \\
\hline غير دالة & $\cdot, 01$ & $r, 11$ & $|\cdot, r|$ & $1, \wedge \varepsilon$ & $1 \cdot, 01$ & مكافأة الذات & 11 \\
\hline غير دالة & $1, r_{1}$ & $r, \cdot \varepsilon$ & $11, \cdot 9$ & $1, \wedge \mathrm{V}$ & $1 \cdot, 7 r$ & تتشيط الاهتمام & IT \\
\hline$\cdot, \cdot 0$ & $* Y, Y \tau$ & $10, \Sigma$ & $1 T \cdot, 1$ & Ir,. & $\mid r \varepsilon, 1$ & الدرجة الكلية & Ir \\
\hline
\end{tabular}

ويتضح من جدول (آ) عدم وجود فروق دالة بــين متوســـي درجـات

ذكور و إناث المرحلة الثانوية في معظم استر اتيجيات التعلم المنظم ذاتيــا، عـدـا

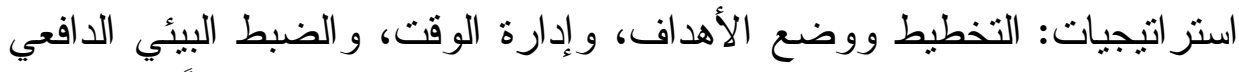
و الدرجة الكلية فكانت لصاح الإناث، وبالتالي تم ضم المجمو عتنين معا. يتضح من جداول (ع، 0، 1) عدم وجود فروق دالة بين الذكور و الإناث

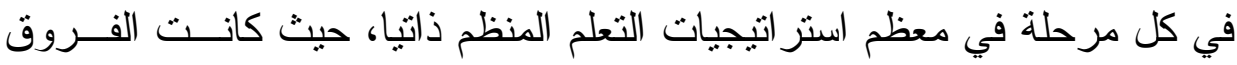

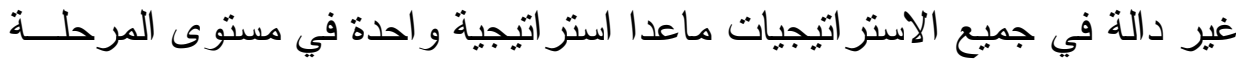

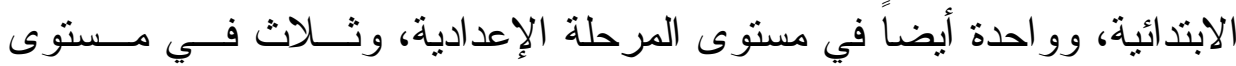

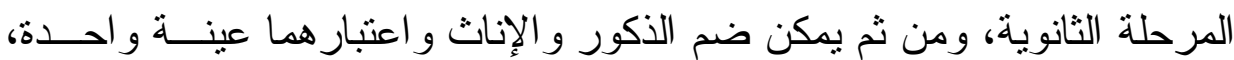

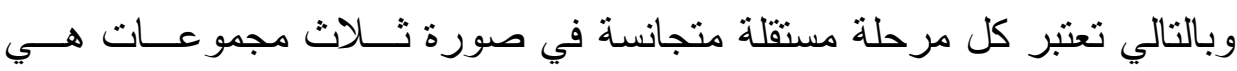
ابتدائي، و إعدادي، وثنانوي. 
أداة الدراسة: مقياس استراتيجيات التعلم المنظم ذاتيا:

قام الباحثون بإعداد مقياس استر اتيجيات التعلم المنظم ذاتيا من خلال تبنى التئ

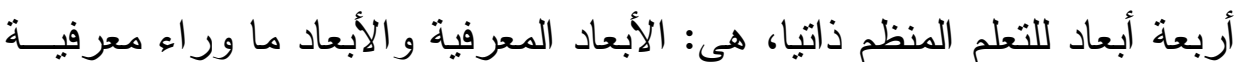
و أبعاد إدارة المصادر و أبعاد الدافعية.

ويتكون كل بعد من تلأك الأبعاد من مجمو عة من الاستر اتيجيات الخاصـــة

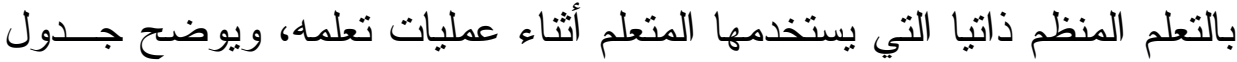
هذه الأبعاد و استر اتيجياتها و أرقام مفردات كل منها. (V)

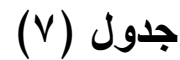

أبعاد مقياس التعلم المنظم ذاتياً واستر اتيجياتها وأرقام مفردات

\begin{tabular}{|c|c|c|c|c|}
\hline المفردات & الاستر اتيجيات & م & أبعاد & s \\
\hline 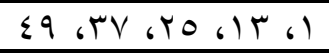 & التنميع - التميع & 1 & \multirow[t]{3}{*}{ معرفية } & \\
\hline $0 ., r \wedge, r 4,6) \leqslant, r$ & التتظيح و النحويل & r & & \\
\hline $01,496,4 V 610,4$ & الاحتفاظ بالسجلات & $r$ & & \\
\hline Or 6 & التخطيط ووضع الأهداف & $\varepsilon$ & \multirow{3}{*}{ معرفية } & \multirow[t]{3}{*}{ r } \\
\hline Or & البحث عن المعلومات & 0 & & \\
\hline $0 \leqslant 6 \leqslant r, r \cdot, 1 \wedge, 7$ & التقويم الذاتيى & 7 & & \\
\hline 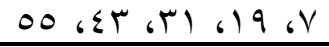 & طلب العون و المساعدة الأكاديمية & $\mathrm{v}$ & \multirow{3}{*}{ مضادرة } & \multirow[t]{3}{*}{ r } \\
\hline 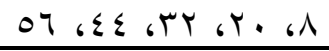 & إدارة الوقت & $\Lambda$ & & \\
\hline OV، & تعلم الأقر ان & 9 & & \\
\hline 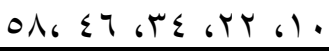 & الضبط البيئي الدافعى & 1. & \multirow[t]{3}{*}{ الدافعية } & \multirow[t]{3}{*}{$\varepsilon$} \\
\hline 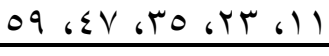 & مكافأة الذات & 11 & & \\
\hline 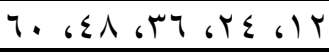 & تتشيط الاهتمام & ir & & \\
\hline
\end{tabular}

ومن ثم تكونت الصورة الأولية لمقياس استراتيجيات التعلم المنظم ذاتيا من (־T) مفردة لقياس (Y I) إستراتيجية بو اقع (0) مفردات لقياس كل استراتيجية منها. وقد حرص الباحثون على عدم زيادة عدد المفردات لضمان ملائمة المقياس للمستويات الدراسية لطلاب المر احل الدراسية الثلاث من حيث

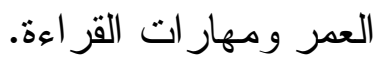


الخصائص السيكومترية لمقياس استراتيجيات التعلم المنظم ذاتيا:

تم حساب الخصائص السيكومترية لمقياس استر اتيجيات التعلم المنظم ذاتيا

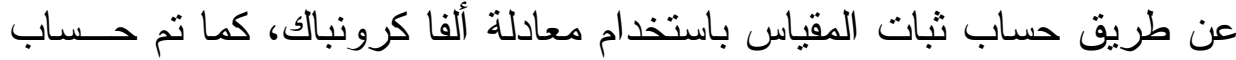
صدقه باستخدام طريقتي: صدق المحتوى، وصدق الاتساق الداخلي.

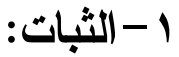

قام الباحثون بحساب ثنات المقياس بطريقة التباين عن طريق معادلة ألفا

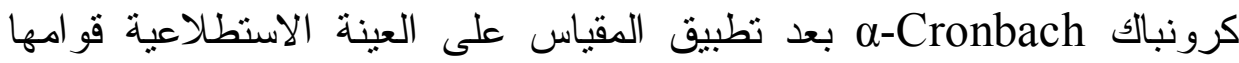

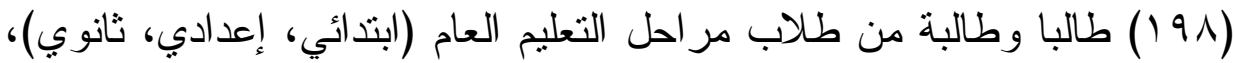

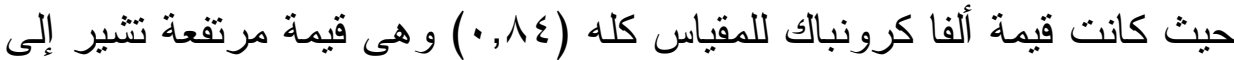

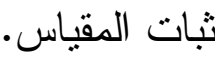

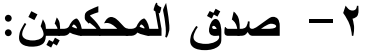

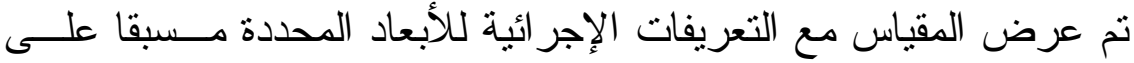

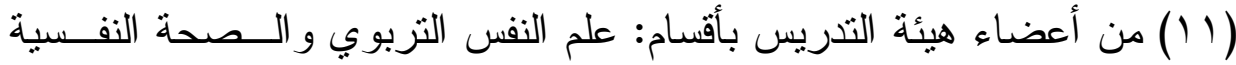

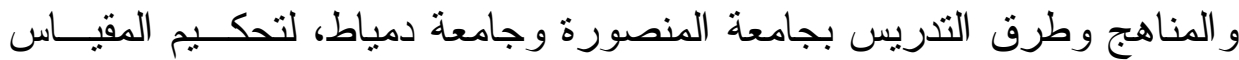

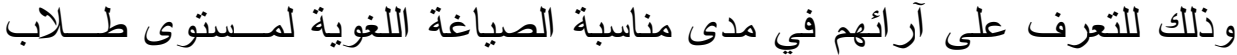

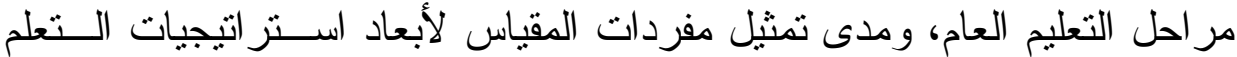

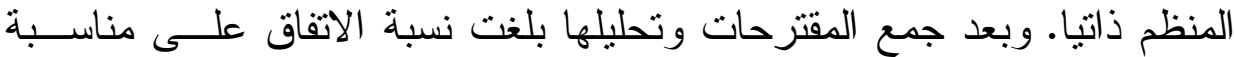
العبارات، وتمثيل مفردات المقياس لأبعاد استر اتيجيات التعلم المنظم ذاتيا، بــين

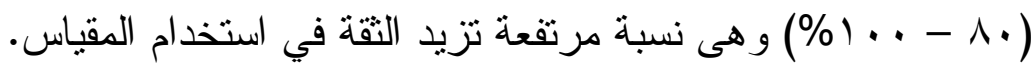

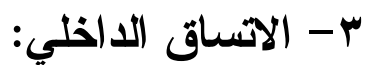

قام الباحثون بحساب دلالة معاملات الارتباط البينية لأبعاد المقياس،

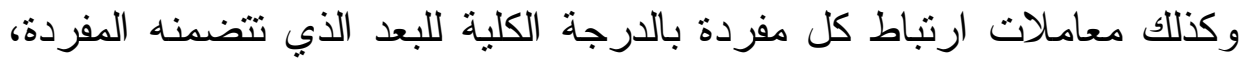

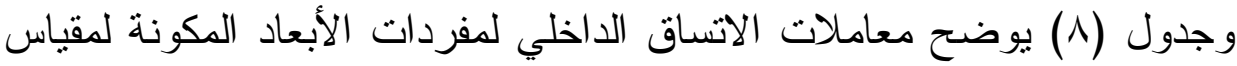
استر اتيجيات التعلم المنظم ذاتيا لدى طلاب المرحلة الابندائية. 


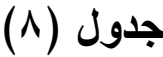

معاملات الاتساق الداخلي لمفردات الأبعاد المكونة لمقياس استراتيجيات

التعلم المنظم ذاتيا (ن= 17 طالب للمرحلة الابتدائية)

\begin{tabular}{|c|c|c|c|c|c|c|c|}
\hline معامباط & المفردمة & الاستر اتيجية & r & الارتباط & المفردُّة & الاستر اتيجية & b \\
\hline$* *, 00$ & $\mathrm{~V}$ & \multirow{5}{*}{ طلب الأكاديمي } & \multirow{5}{*}{ v } & $* *, \leqslant 9$ & 1 & \multirow{5}{*}{ التسميع } & \multirow{5}{*}{1} \\
\hline$* *, 01$ & 19 & & & $* *, 09$ & $\pi$ & & \\
\hline$* *, 7 \mathrm{~V}$ & Tा & & & **, $\leqslant 0$ & TO & & \\
\hline$\cdot, 17$ & $\sum \Gamma$ & & & $\% *, \vee v 0$ & $\overline{T V}$ & & \\
\hline$* \%, 70$ & 00 & & & **,OY & ह9 & & \\
\hline$* *, 01$ & $\Lambda$ & \multirow{5}{*}{ إدارة الوقت } & \multirow{5}{*}{$\wedge$} & **\%, rV & T & \multirow{5}{*}{ التظظيم } & \multirow{5}{*}{ r } \\
\hline$* *, 0$. & r. & & & **.,09 & $1 \varepsilon$ & & \\
\hline ***, & TY & & & **.,Or & rq & & \\
\hline$* *, 70$ & $\varepsilon \varepsilon$ & & & **\%, TY & rN & & \\
\hline$*, Y V$ & 07 & & & **, & 0. & & \\
\hline **, $7 Y$ & 9 & \multirow{5}{*}{ تعلم الأفر ان } & \multirow{5}{*}{9} & ***,Vo & $\Gamma$ & \multirow{5}{*}{ الاحتفاظ بالسجلات } & \multirow{5}{*}{ r } \\
\hline$* \%, O Y$ & YI & & & ***,TY & 10 & & \\
\hline ***, & Tr & & & *\%०, & TV & & \\
\hline ***,7) & $\leqslant 0$ & & & $* *, 7 \wedge$ & एव & & \\
\hline *\%०, $0 \leqslant$ & OV & & & $\cdot, Y \cdot$ & 01 & & \\
\hline **., & $1 \cdot$ & \multirow{5}{*}{ الضبط البيئى } & \multirow{5}{*}{$1 \cdot$} & $* *, \leqslant 7$ & $\varepsilon$ & \multirow{5}{*}{ التخطيط وئس الإضع } & \multirow{5}{*}{$\varepsilon$} \\
\hline **, & YY & & & **, TV & 17 & & \\
\hline 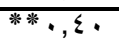 & एद & & & $* *, \leqslant q$ & TA & & \\
\hline$* *, 07$ & $\varepsilon 7$ & & & $* *, r \Gamma$ & $\varepsilon$. & & \\
\hline ***, & 01 & & & **, $0 \leqslant$ & Or & & \\
\hline ***, & $\pi$ & \multirow{5}{*}{ مكافأة الذات } & \multirow{5}{*}{11} & **., 70 & 0 & \multirow{5}{*}{ البحلث ماتي } & \multirow{5}{*}{0} \\
\hline ***,01 & Tr & & & ***, 71 & TV & & \\
\hline$* *, \varepsilon \wedge$ & ro & & & $* *, \Sigma \Lambda$ & rq & & \\
\hline$* *, \Sigma V$ & $\varepsilon V$ & & & $* \%, 00$ & $\xi 1$ & & \\
\hline **.,, • & 09 & & & ***, 00 & Or & & \\
\hline **.,Or & Tr & \multirow{5}{*}{ تتشيط الاهتمام } & \multirow{5}{*}{ ir } & ***,TY & 7 & \multirow{5}{*}{ التقويم الذاتي } & \multirow{5}{*}{7} \\
\hline$\cdot, 19$ & T纟 & & & **, & 11 & & \\
\hline *ै, & ri & & & **,,$V$. & $r \cdot$ & & \\
\hline$* *, 0$. & $\varepsilon \wedge$ & & & **, & $\sum Y$ & & \\
\hline 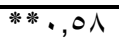 & 7. & & & **., $0 \leqslant$ & $0 \xi$ & & \\
\hline
\end{tabular}

ويتضح من جدول (^) أن معظم مفردات المقياس دالة مما بيدل على

تجانس مفردات المقياس وتمثيلها للبعد الذى تقيسه عدا المفردات رقم (ع ب، بـ؛، 10) ذات معاملات ارتباط غير دالة ، ويوضح جدول (9) (9) معاملات الاتساق

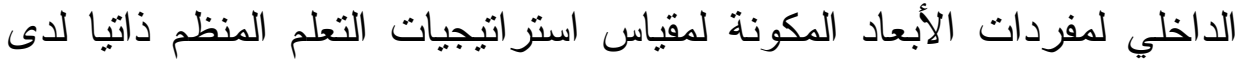
طلاب المرحلة الإعدادية. 


\section{جدول (9)}

معاملات الاتساق الاخلي لمفردات الأبعاد المكونة لمقياس استراتيجيات التعلم

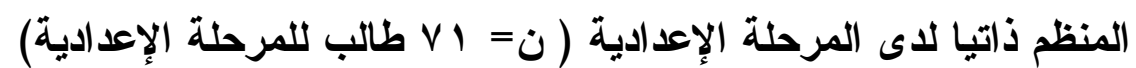

\begin{tabular}{|c|c|c|c|c|c|c|c|}
\hline الارتباط & المفردة & الاستر اتيجية & م & الارتباط معل & المفردة & الاستر اتيجية & 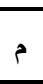 \\
\hline$* *, T V$ & $\mathrm{~V}$ & \multirow{5}{*}{ طلب الأكاديمي } & \multirow{5}{*}{ v } & ***, & 1 & \multirow{5}{*}{ التسميع } & \multirow{5}{*}{1} \\
\hline$* *, \varepsilon r$ & 19 & & & $* *, \leqslant 0$ & $1 \pi$ & & \\
\hline$* *, 01$ & r & & & ***,T) & ro & & \\
\hline$* *, \Gamma V$ & $\sum r$ & & & ***, & $r v$ & & \\
\hline$m *, 0 \leqslant$ & 00 & & & ***,OY & $\varepsilon 9$ & & \\
\hline$* *, T r$ & $\Lambda$ & \multirow{5}{*}{ إدارة الوقت } & \multirow{5}{*}{$\wedge$} & $* *, 79$ & $r$ & \multirow{5}{*}{ التنظيم } & \multirow{5}{*}{ r } \\
\hline$* \%, 0 \mathrm{~V}$ & r. & & & ****, & $1 \varepsilon$ & & \\
\hline$* *, \varepsilon V$ & rr & & & $* * \cdots, 07$ & KT & & \\
\hline$* *, 0 \mathrm{~V}$ & $\varepsilon \varepsilon$ & & & ***, & rᄉ & & \\
\hline$* *, 0 \mathrm{~V}$ & 07 & & & ***,VI & 0. & & \\
\hline$* *, \varepsilon Y$ & 9 & \multirow{5}{*}{ تعلم الأقران } & \multirow{5}{*}{9} & $* * \cdot 09$ & $r$ & \multirow{5}{*}{ الاحتفاظ بالسجلات } & \multirow{5}{*}{ r } \\
\hline$* *, 7 \wedge$ & YI & & & ***, & 10 & & \\
\hline$* *, \varepsilon r$ & r & & & $* *, 00$ & TV & & \\
\hline$* *, 79$ & $\varepsilon 0$ & & & ***., & rq & & \\
\hline$* *, 70$ & ov & & & 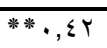 & 01 & & \\
\hline 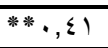 & 1. & \multirow{5}{*}{ الضبط البيئي } & \multirow{5}{*}{$1 \cdot$} & ***. & $\varepsilon$ & \multirow{5}{*}{ التخطبط ووضع } & \multirow{5}{*}{$\varepsilon$} \\
\hline$* *, 7$. & rr & & & ***, & 17 & & \\
\hline$* *, 7 \wedge$ & $\Gamma \leq$ & & & $* * \cdot 09$ & $r \wedge$ & & \\
\hline$* *, \leqslant 9$ & $\sum 7$ & & & 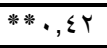 & $\varepsilon \cdot$ & & \\
\hline$* *, \varepsilon r$ & 01 & & & $* *, V \varepsilon$ & or & & \\
\hline$* *, 7 \wedge$ & 11 & \multirow{5}{*}{ مكافأة الذات } & \multirow{5}{*}{11} & $* *, O \mathrm{~V}$ & 0 & \multirow{5}{*}{ البحث عن المعلومات } & \multirow{5}{*}{0} \\
\hline$* *, 07$ & $r r$ & & & 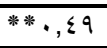 & IV & & \\
\hline$* *, \varepsilon r$ & ro & & & $* *, 7 Y$ & rq & & \\
\hline$* *, 0 \leqslant$ & $\varepsilon V$ & & & ***, $\cdot$. & 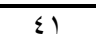 & & \\
\hline$* *, 00$ & 09 & & & ***,Or & or & & \\
\hline$* *, \varepsilon \wedge$ & ir & \multirow{5}{*}{ تتشيط الاهتمام } & \multirow{5}{*}{ ir } & ***., & 7 & \multirow{5}{*}{ الثقويم الذاتي } & \multirow{5}{*}{7} \\
\hline 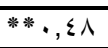 & $r \leq$ & & & $* * *, V Y$ & 11 & & \\
\hline$* *, 07$ & $r$ & & & $* *, \varepsilon, \Sigma Y$ & $r$. & & \\
\hline$* *, \leqslant 9$ & $\varepsilon \wedge$ & & & $* *, 7 \wedge$ & $\varepsilon r$ & & \\
\hline$* *, 0 \leqslant$ & 7. & & & $* *, T \mathrm{~V}$ & $0 \leqslant$ & & \\
\hline
\end{tabular}

ويتضح من جدول (9) أن معاملات الارنباط جميعها دالة، مما يدل على دولى

تجانس مفردات المقياس وتمثيلها للبعد الذى تقيسه. ويوضح جدول (·) (1) 
معاملات الاتساق الداخلي لمفردات الأبعاد المكونة لمقياس استراتيجيات التعلم المنظم ذاتبا لدى المرحلة الثانوية.

$$
\text { جدول (·) (1) }
$$

معاملات الاتساق الداخلي لمفردات الأبعاد المكونة لمقياس استراتيجيات التعلم

المنظم ذاتيا لاى المرحلة الثانوية ( ن= 7 الت طالب للمرحلة الثانوية)

\begin{tabular}{|c|c|c|c|c|c|c|c|}
\hline الارتباط & المفردمة & الاستر اتيجية & م & الارتباط & المفردُة & الاستر اتيجية & b \\
\hline ***,TV & $V$ & \multirow{5}{*}{ طلإب العون } & \multirow{5}{*}{ v } & **,r. & 1 & \multirow{5}{*}{ التسميع } & \multirow{5}{*}{1} \\
\hline ***, $\{\Sigma V$ & 19 & & & ***, $\vee \wedge$ & $\pi$ & & \\
\hline$* *, V 1$ & $r$ & & & $\because *, 7$. & ro & & \\
\hline **ँ,々। & $\varepsilon r$ & & & ***, $7 Y$ & $r V$ & & \\
\hline ***, \{\rceil & 00 & & & ***,, $7 \varepsilon$ & $\sum 9$ & & \\
\hline ***,7) & $\wedge$ & \multirow{5}{*}{ إدارة الوقت } & \multirow{5}{*}{$\wedge$} & $* *, 77$ & $r$ & \multirow{5}{*}{ التظيم } & \multirow{5}{*}{ r } \\
\hline$* *, 07$ & $r \cdot$ & & & $* *, \leqslant 7$ & $1 \varepsilon$ & & \\
\hline ***, 0 . & MY & & & $* *, 09$ & YY & & \\
\hline$* *, 09$ & $\varepsilon \varepsilon$ & & & $* *, 7 r$ & $r \Lambda$ & & \\
\hline ***,々) & 07 & & & ***, OV & 0. & & \\
\hline ***,,$V \cdot$ & 9 & \multirow{5}{*}{ تعلم الأفران } & \multirow{5}{*}{9} & $* *, V \varepsilon$ & $r$ & \multirow{5}{*}{ الاحتفاظ بالسجلات } & \multirow{5}{*}{ r } \\
\hline ***, & YI & & & $* *, 7 \wedge$ & 10 & & \\
\hline$* *, V \Gamma$ & r & & & ***, $0 \leqslant$ & TV & & \\
\hline$* *, 7 \wedge$ & $\varepsilon 0$ & & & $* *, 7 \wedge$ & rq & & \\
\hline$* *, \wedge$. & ov & & & ***,OY & 01 & & \\
\hline ***, & 1. & \multirow{5}{*}{ الضبط البيئي } & \multirow{5}{*}{1.} & $* *, V Y$ & $\varepsilon$ & \multirow{5}{*}{ التخطبط ووضع } & \multirow{5}{*}{$\varepsilon$} \\
\hline$* *, \vee \vee 9$ & TY & & & $* *, 7)$ & 17 & & \\
\hline ***, $7 \varepsilon$ & $\Gamma \varepsilon$ & & & ***, VO & YA & & \\
\hline **\%, TV & $\xi 7$ & & & ***, & $\varepsilon$. & & \\
\hline ***, 07 & 01 & & & ***, 70 & OY & & \\
\hline ***,,$\vee \cdot$ & 11 & \multirow{5}{*}{ مكافأة الذات } & \multirow{5}{*}{11} & $* *, 07$ & 0 & \multirow{5}{*}{ المعلو مات عن } & \multirow{5}{*}{0} \\
\hline 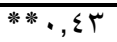 & $\overline{r r}$ & & & ***, $7 \varepsilon$ & TV & & \\
\hline 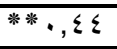 & ro & & & $* *, 0 \mathrm{~V}$ & rq & & \\
\hline$* *, 79$ & $\sum V$ & & & $* *, V Y$ & $\Sigma 1$ & & \\
\hline ***, & 09 & & & $* *, 71$ & or & & \\
\hline ***,rq & $\pi$ & \multirow{5}{*}{ تتشيط الاهتمام } & \multirow{5}{*}{ ir } & $* *, 7 \wedge$ & 7 & \multirow{5}{*}{ التقويم الذاتي } & \multirow{5}{*}{7} \\
\hline **., Or & $T \leq$ & & & $* *, \varepsilon Y$ & 11 & & \\
\hline$* *, 01$ & $r$ & & & $* *, 77$ & $r \cdot$ & & \\
\hline ***, 70 & $\varepsilon \wedge$ & & & $* *, 01$ & $\varepsilon r$ & & \\
\hline$* *, r q$ & 7. & & & ***, $7 \wedge$ & $0 \leqslant$ & & \\
\hline
\end{tabular}


ويتضح من جدول (·1) أن معاملات الارتباط جميعها دالة، مما يدل

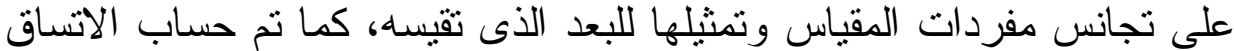

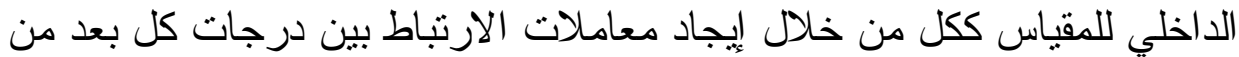

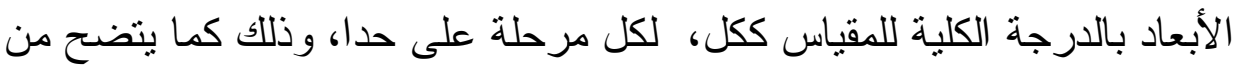

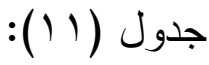

\section{جدول (11)}

معاملات ارتباط الارجة الكلية لكل بعد بالدرجة الكلية للمقياس

\begin{tabular}{|c|c|c|c|c|}
\hline ثانوي & إعدادي & ابتدائي & \multirow{2}{*}{ الاستر اتيجيات } & \multirow{2}{*}{ b } \\
\hline معامل الارتباط & معامل الارتباط & معامل الارتباط & & \\
\hline$* *, 0 \cdot 1$ & $* *, 0 \leq 7$ & $*$ *, $\leqslant$ Or & 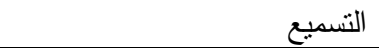 & 1 \\
\hline$* *, \vee>0$ & $* *, 799$ & $* *, \leqslant \wedge 0$ & 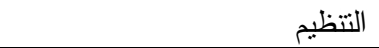 & r \\
\hline$* *, 77 \wedge$ & $* *, \leqslant \circ V$ & $*, 0 \wedge r$ & الاحتفاظ بالسجلات & r \\
\hline$* *, \mathrm{~V} \circ \mathrm{V}$ & **, T人 & $* *, 00$ & التخطبط ووضع الأهداف & $\varepsilon$ \\
\hline$* *, T Y 1$ & **⿻, Tト人 & *., Or. & البحث عن المعلومات & 0 \\
\hline$* *, 7 \varepsilon$ & **, Tor & $*, 001$ & التقويم الذاتي & 7 \\
\hline$* *, \leqslant$ ४ & $* *, r Y q$ & $\cdot, I V T$ & طلب العون و المساعدة الأكاديمية & $\checkmark$ \\
\hline$* *, 7 \cdot 1$ & $* *, \Upsilon \wedge 1$ & $* *, \Sigma \Gamma$. & إدارة الوقت & $\wedge$ \\
\hline$* *, 79 \mathrm{~V}$ & $* *, 7 r q$ & $* *, T Y \leq$ & تعلم الأقران & 9 \\
\hline **,人从 & $* *, 017$ & $* *, 7) \wedge$ & الضبط البيئي الدافعي & 1. \\
\hline$* *, 7 \cdot 1$ & $* *, \Sigma .0$ & $* *, \Sigma)$. & مكافأة الذات & 11 \\
\hline$* \%, 707$ & $* *, 7 \leq 1$ & $* *, 0 M 1$ & تتشيط الاهتمام & ir \\
\hline & & ل لة عند مستوى & عند مستوى 0., • & "دال \\
\hline
\end{tabular}

يتضح من جدول (1) (1) أن معامل ارتباط الدرجة الكلية لكل بعد بالدرجة الكلية للمقياس دال عند مستوى الدلالة (1 ., •) أي أن الأبعاد المكونة للمقياس

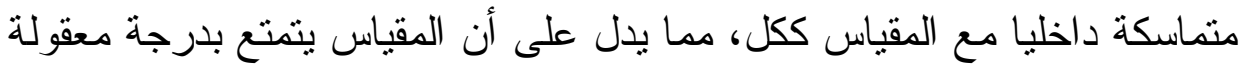

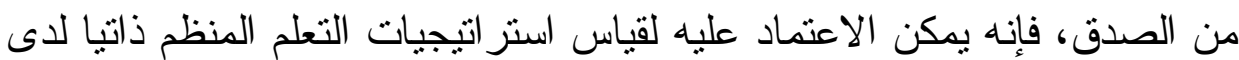
طلاب مر احل التعليم العام (ابتدائي، إعدادي، ثنانوي). 
يتتاول الباحثون فيما يلي نتائج اختبار فروض الدراسة باستخدام الاختبار ات و الأساليب الإحصائية الملائمة. أولا: النتائج المتعلقة بالفرض الأول:

ينص الفرض الأول على أنه: يستخدم طلاب كل مرحلة من مراحل

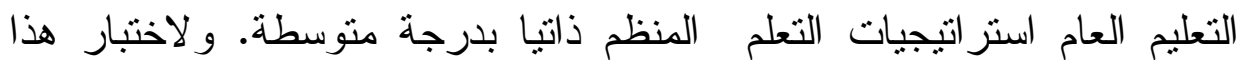

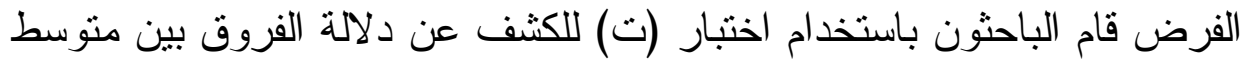
تجريبي ومتوسط افتر اضي (نقطة ثابتة متوسطة)، حيث تم حساب المتوسطات

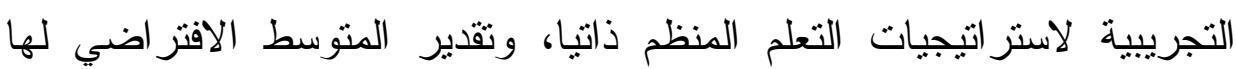
(النقطة الثابتة المنوسطة التي تقدر بعدد المفردات الخاصة بكل بعد وهي (ن) مفردات مضروباً في (r) وهي قيمة الاستجابة المتوسطة لكل مفردة ليكون

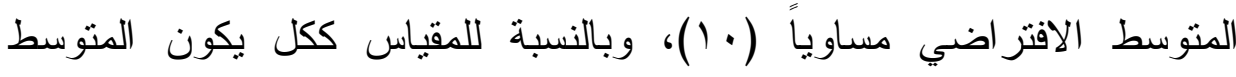

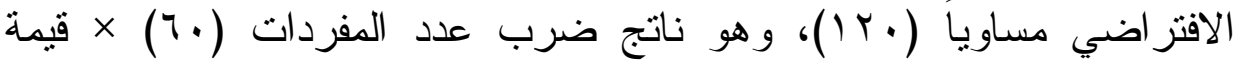
الاستجابة المتوسطة (r). ويوضح جدول (r) دلالة الفروق بين المتوسطات التجريبية و الافتر اضية لاستر اتيجيات التعلم المنظم ذاتيا لكل مرحلة من المر احل

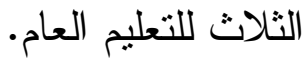




\section{جذول (r ا I)}

دلالة الفروق بين المتوسطات التجريبية والافتر اضية لاستر اتيجيات التعلم

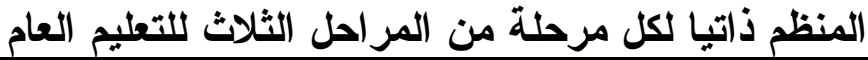

\begin{tabular}{|c|c|c|c|c|c|c|}
\hline الالالةي & قيمة (ت) & لد.ح. & الألمتر اضيط & التجريبي & الاستر اتيجية & المرحلة \\
\hline$\cdot, \cdot 1$ & 9,17 & Trर & 1 & $11, v \wedge$ & التسميع & \multirow[t]{13}{*}{ الابتدائية } \\
\hline$\cdot, \cdot 1$ & $\Lambda, \Sigma V$ & $T \pi$ & $1 \cdot$ & $11,0$. & التتظيم & \\
\hline$\cdot, \cdot 1$ & $0, Y Y$ & $T \pi$ & 1. & $1 \cdot, 9 r$ & الاحتفاظ بالسجلات & \\
\hline$\cdot, \cdot 1$ & $9, \leqslant 7$ & $T \pi$ & $1 \cdot$ & $11,9 \varepsilon$ & التخطبط ووضع الأهداف & \\
\hline$\cdot, \cdot 1$ & $V, 1 \varepsilon$ & $T \pi$ & $1 \cdot$ & 11,4 & البحث عن المعلومات & \\
\hline$\cdot, \cdot 1$ & $1 \cdot, Y Y$ & $T \pi$ & $1 \cdot$ & 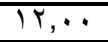 & التقويم الذاتي & \\
\hline$\cdot, .0$ & 1,91 & $T \pi$ & $1 \cdot$ & 9,71 & طلب العون الاكاديمي & \\
\hline$\cdot, \cdot, 1$ & $\Lambda, \wedge$. & TrA & $1 \cdot$ & $11,7 \wedge$ & إدارة الوقت & \\
\hline., .0 & $T, .0$ & $1 \mathrm{TN}$ & 1. & $1 \cdot, \mathrm{rV}$ & تعلم الأقران & \\
\hline$\cdot, \cdot 1$ & $V, V V$ & $T \pi$ & $1 \cdot$ & 11,01 & الضبط البيئي الدافعي & \\
\hline$\cdot, .0$ & $T, I V$ & 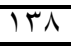 & $1 \cdot$ & $1 \cdot, \Sigma Y$ & مكافأة الذات & \\
\hline$\cdot, \cdot 1$ & $\sum, \Gamma$ & TrA & 1. & $1 \cdot, \times 7$ & تتشيط الاهتمام & \\
\hline$\cdot, \cdot 1$ & $1 \cdot, 70$ & 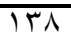 & $T r$ & $1 \pi r, 9$ & الدرجة الكلية & \\
\hline$\cdot, \cdot 1$ & $\varepsilon, \cdot 1$ & $1 \leqslant \Lambda$ & $1 \cdot$ & $1 \cdot, V T$ & التسميع & \multirow[t]{13}{*}{ الإعدادية } \\
\hline$\cdot, \cdot 1$ & $V, .0$ & $1 \leqslant \Lambda$ & $1 \cdot$ & $11, Y \leq$ & النتظيح & \\
\hline$\cdot, \cdot 1$ & 0,0 & $T \leqslant \Lambda$ & $1 \cdot$ & $1 \cdot, 90$ & الاحتفاظ بالسجلات & \\
\hline$\cdot, \cdot 1$ & $9, \cdot \varepsilon$ & $1 \leqslant \Lambda$ & 1 . & $11, v$. & التخطبط ووضع الأهداف & \\
\hline$\cdot, \cdot 1$ & $V, .9$ & $T \leqslant \Lambda$ & $1 \cdot$ & 11,11 & البحث عن المعلومات & \\
\hline$\cdot, \cdot 1$ & $9,0 Y$ & $1 \leq \Lambda$ & $1 \cdot$ & $11, V Y$ & التقويم الذاتي & \\
\hline$\cdot, \cdot 1$ & 0,19 & $T \leqslant \Lambda$ & $1 \cdot$ & $1 \cdot, \wedge 7$ & طلب العون الاكاديمي & \\
\hline$\cdot, \cdot 1$ & 7,10 & $T \leqslant \Lambda$ & T. & $11, .9$ & إدارة الوقت & \\
\hline$\cdot, \cdot 1$ & $\varepsilon, \varepsilon \varepsilon$ & $T \leqslant \Lambda$ & 1. & $1 \cdot, \wedge \cdot$ & تعلم الأفران & \\
\hline$\cdot, \cdot 1$ & $\Lambda, \cdot r$ & $T \leqslant \Lambda$ & $1 \cdot$ & $11, \varepsilon \pi$ & الضبط البيئي الدافعي & \\
\hline$\cdot, \cdot 1$ & $\varepsilon, 0 \mathrm{~V}$ & $1 \leqslant \Lambda$ & $1 \cdot$ & $1 \cdot, 199$ & مكافأة الذات & \\
\hline$\cdot, \cdot 1$ & $0,7 \Lambda$ & $T \leqslant \Lambda$ & 1. & 11,00 & تتشيط الاهتمام & \\
\hline$\cdot, \cdot 1$ & $1 \cdot, 10$ & $T \leqslant \Lambda$ & $\pi \cdot$ & $1 M T, 0$ & الدرجة الكلية & \\
\hline$\cdot, \cdot 1$ & Y,VO & TKV & $1 \cdot$ & $1 \cdot, \Sigma \Lambda$ & التشميع & \multirow[t]{13}{*}{ الثانوية } \\
\hline غير دالة & 1,17 & ITV & $1 \cdot$ & $1 \cdot, Y T$ & النتظيح & \\
\hline غير دالة & $1, \wedge V$ & TRV & T. & I., & الاحتفاظ بالسجلات & \\
\hline$\cdot, \cdot 1$ & $0, r V$ & ITV & $1 \cdot$ & $11, \cdots$ & التخطيط ووضع الأهداف & \\
\hline$\cdot, \cdot 1$ & r,Tr & TKV & $1 \cdot$ & $1 \cdot, 01$ & البحث عن المعلومات & \\
\hline$\cdot, \cdot 1$ & $0, \leqslant 0$ & ITV & $1 \cdot$ & $11, \cdot 1$ & التقويم الذاتي ــ & \\
\hline غير دالة & $1, Y \Sigma$ & TrV & $1 \cdot$ & $1 \cdot, 19$ & طلب العون الاكاديمي & \\
\hline$\cdot, \cdot 1$ & $\varepsilon, \Gamma V$ & IKV & $1 \cdot$ & $1 \cdot, 97$ & إدارة الوقت & \\
\hline$\cdot, .0$ & $r, \xi$. & TRV & $1 \cdot$ & $1 \cdot, \leqslant 1$ & تعلم الأفران & \\
\hline$\cdot, \cdot 1$ & $r, 91$ & ITV & $1 \cdot$ & $1 \cdot, \mathrm{VT}$ & الضبط البيئي الدافعي & \\
\hline$\cdot, .0$ & Y,O & $T K V$ & $1 \cdot$ & $1 \cdot, \leq \leqslant$ & مكافاة الذات & \\
\hline$\cdot, \cdot 1$ & $\varepsilon, \vee 7$ & ITV & $1 \cdot$ & $1 \cdot, \Lambda Y$ & تتشيط الاهتمام & \\
\hline$\cdot, \cdot 1$ & $0,7 \pi$ & $T K V$ & $T r$ & $1 Y 7, \Lambda$ & الدرجة الكلية & \\
\hline
\end{tabular}


يتضح من جدول (Y T) ان قيم المتوسطات التجرييية تفوق قيمة المتوسط

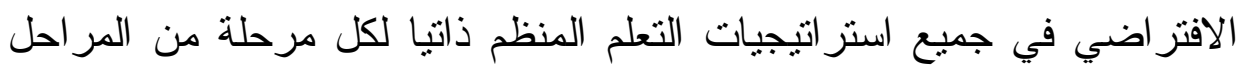

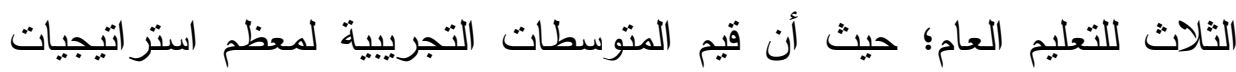

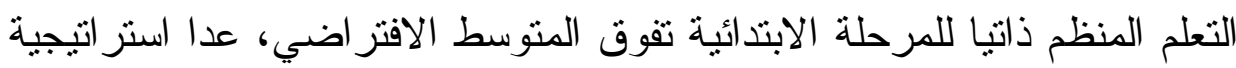
طلب العون الاكاديمي التي جاءت أقل من المتوسط. كما يتضح وجود فروق دالة بين المتوسطات التجريبية والمتوسطات

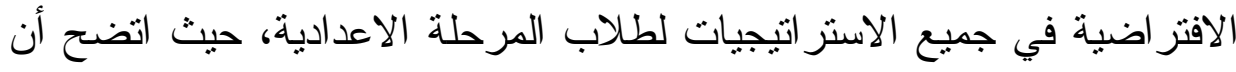

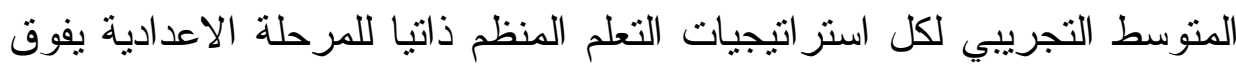

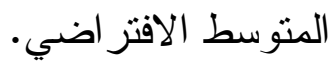
ويتضح أيضاً وجود فروق دالة بين المتوسطات التجريبية و المنوسطات

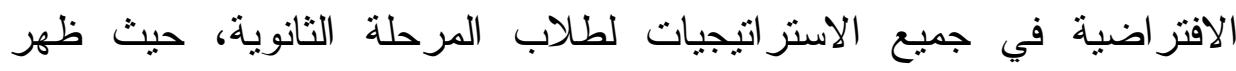

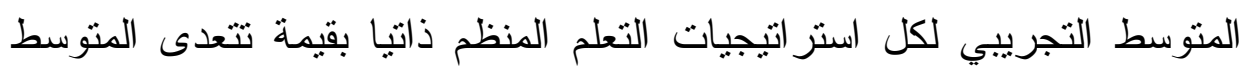

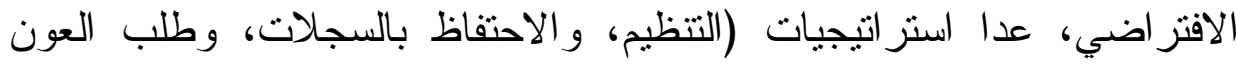

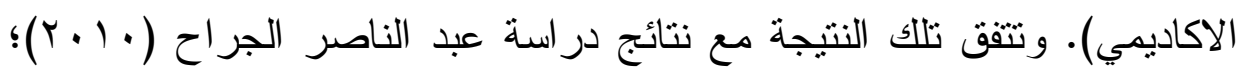
حيث أسفرت نتائجها عن امتلاك طلبة جامعة اليرموك مكونات التعلم المنظم

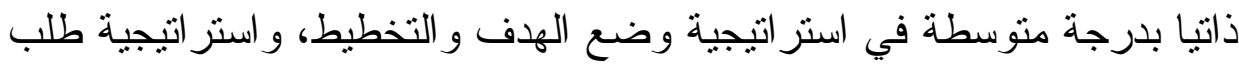

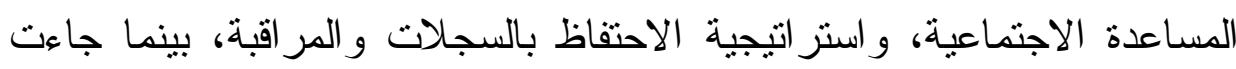

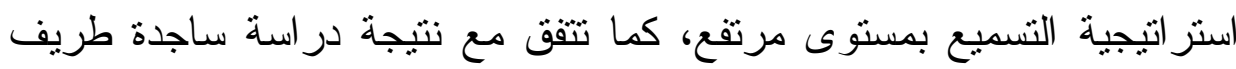

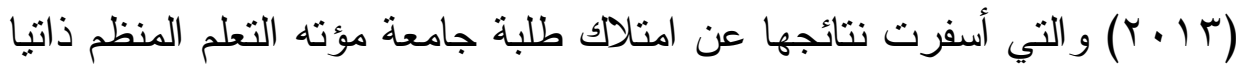
بدرجة متوسطة. 


\section{ثانياً: النتائج المتعلقة بالفرض الثاني:}

ينص الفرض الثاني على أنه: ترنبط استراتيجيات التعلم المنظم ذاتيا بالتحصيل الدراسي لدى طلاب كل مرحلة من مر احل التعليم العام (ابتدائي،

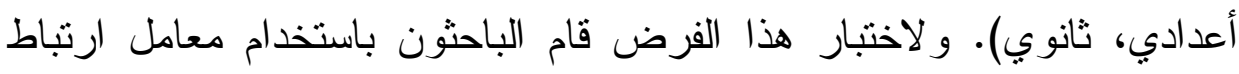
بيرسون للكثف عن دلالة العلاقة بين درجات استر اتيجيات التعلم المنظم ذاتيا ودرجات التحصيل الدراسي لاى طلاب كل مرحلة من المر احل الثثلاث للتعليم

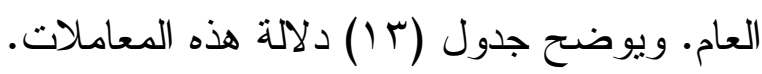

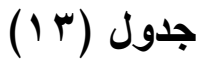

دلالة معاملات الارتباط بين درجات استراتيجيات التعلم المنظم ذاتيا ودرجات التحصيل الاراسي لاى طلاب كل مرحلة من المراحل الثُلاث للتعليم العام

\begin{tabular}{|c|c|c|c|}
\hline \multicolumn{3}{|c|}{ معاملات الارتباط بين الاستر اتيجية والتحصيل ومستوى دلالتها } & \multirow{2}{*}{ 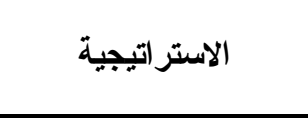 } \\
\hline 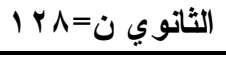 & الإعدادي ن=9 = & 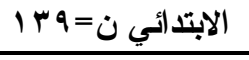 & \\
\hline$* *, 00$ & $* *, 0 \leqslant 0$ & $* *,, \leq \uparrow \wedge$ & التسميع \\
\hline$* *,, \leqslant \wedge 0$ & $* *, 7 \vee \leq$ & $* *, 0 \vee 0$ & التظظيم \\
\hline$* *, \varepsilon \cdot \Lambda$ & $* *, 0 \leq 0$ & $* *, \quad \leq \leqslant 9$ & الاحتفاظ بالسجلات \\
\hline$* *, T ו r$ & $* *, v \leqslant 0$ & 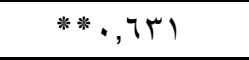 & التخطيط ووضع الأهداف \\
\hline$* *, r q \varepsilon$ & $* *, 00 \mathrm{r}$ & $* *, 7 Y q$ & البحث عن المعلومات \\
\hline$* *, 0 \mathrm{~s} \varepsilon$ & **, Тז人 & $* *$, or $V$ & التقويم الذاتي \\
\hline 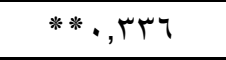 & $* *, \varepsilon \cdot \varepsilon$ & $* *, 1,9$ & طلب العون الأكاديمي \\
\hline$* *, \pi 1 r$ & $* *, O V Y$ & $* *$, or. & إدارة الوقت \\
\hline$* *, \varepsilon \mu r$ & $* *, 0, V$ & $* *, \Gamma \wedge \wedge$ & ت تعلم الأقران \\
\hline$* *, T r$. & $* *, 79 V$ & $* *$, or $r$ & الضبط البيئي الدافعي \\
\hline$* *, Y, Y$ & $* *, r \circ \Lambda$ & $* *, r \wedge$. & مكافأة الذات \\
\hline$* *,, \leq 0 \wedge$ & $* *, 070$ & $* *, r \wedge \wedge$ & تتشيط الاهتمام \\
\hline$* *, \wedge) \leq$ & $* *, 900$ & $* *, \wedge \Gamma$ & الدرجة الكلية \\
\hline$\cdot, \cdot$ & 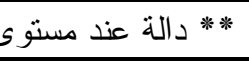 & $\cdot, .0 \mathrm{~s}$ & 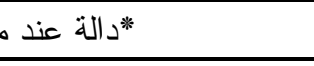 \\
\hline
\end{tabular}


ويتضح من جـدول (r) (I) وجـود ارتبــاط موجــب دال بـين جميـع

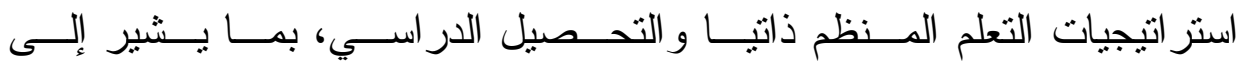

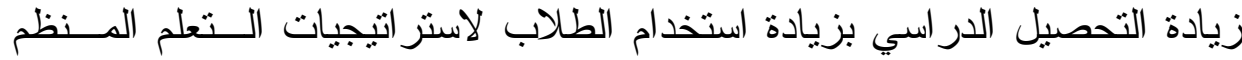

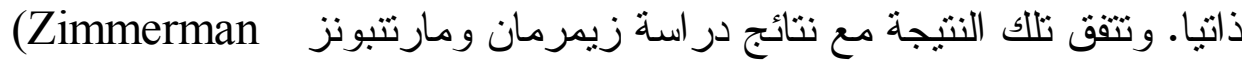

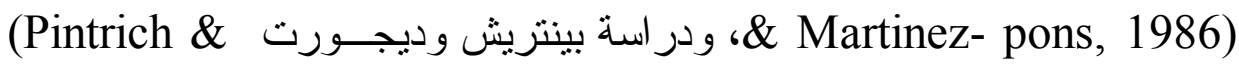

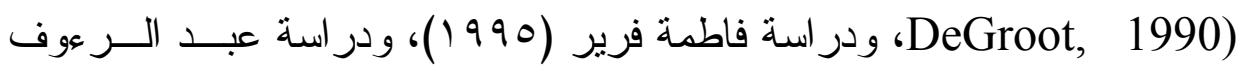

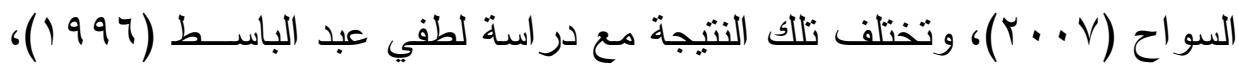

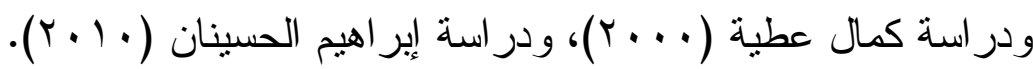
ثالثاً: النتائج المتعلقة بالفرض الثالث:

ينص الفرض الثالث على أنه: تختلف العلاقة بين استراتيجيات التعلم المنظم ذاتيا و التحصيل الدر اسي باختلاف طلاب مر احل التعليم العام (ابتدائي، إعدادي، ثانوي). و لاختبار هذا الفرض قام الباحثون بحساب معامل ارتباط بيرسون للكثف عن دلالة العلاقة بين درجات استر اتيجيات التعلم المنظم ذاتياً ودرجات التحصيل الدراسي لدى طلاب كل مرحلة من المر احل الثثلاث للتعليم العام، ثم استخدام معادلة نسبة الارتباط للمجموعات المستقلة لكو هين، كوهين، ويست و اكين (Cohen, Cohen, West, \& Aiken, 2003 للكثن عن دلالة الفروق بين كل معاملي ارنباط لتحديد مدى اختلاف هذه العلاقة باختلاف المرحلة الدر اسية. ويوضح جدول (ع ال) دلالة هذه الفروق. 


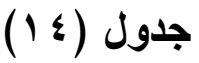

دلالة الفروق بين معاملات الارتباط بين درجات استر اتيجيات التعلم المنظم

ذاتيا ودرجات التحصيل الدراسي للطلاب في المراحل الثُلاث للتعليم العام التئي

\begin{tabular}{|c|c|c|c|c|}
\hline إعدادي & ابتدائي & معامل الارتباط & المرحلة & الاستراتيجية \\
\hline- & - & $* * \cdot, \varepsilon 7 \lambda$ & ابتذائي & \multirow{3}{*}{ التسميع } \\
\hline- & $\cdot, \wedge \mathrm{V}$ & $* *, 0 \leqslant 0$ & إعدادي & \\
\hline$\cdot, \cdot 7$ & $\cdot, 19$ & $* * ., 00$ & ثنانوي & \\
\hline- & - & $* *$, , ovo & ابتذائي & \multirow{3}{*}{ التنظيم } \\
\hline- & $T, r V$ & $* *,, 7 \vee \varepsilon$ & إعدادي & \\
\hline **Y,TV & $1, \cdot T$ & $* *,, \Sigma \wedge 0$ & لَنانوي & \\
\hline- & - & $* *$, , $\leqslant \leqslant 9$ & ابتدائي & \multirow{3}{*}{ الاحتفاظ بالسجلات } \\
\hline- & $1, \cdot V$ & $* *, 0 \leqslant 0$ & إعدادي & \\
\hline $1, \varepsilon 7$ & $\cdot, \xi 1$ & $* *,, \varepsilon \cdot \lambda$ & تُنانوي & \\
\hline- & - & **, Tा & ابتذائي & \multirow{3}{*}{ التخطيط ووضع الأهداف } \\
\hline- & $T, \Lambda T$ & $* *,, V \leqslant 0$ & إعدادي & \\
\hline$* Y, .0$ & $\cdot, 10$ & $* *, T ा T$ & نَانوي & \\
\hline- & - & $* *, 7 r q$ & ابتدائي & \multirow{3}{*}{ البحث عن المعلومات } \\
\hline- & $\cdot, 91$ & $* * ., 001$ & إبادي & \\
\hline 1,79 & **Y, Tा & **, rवद & لَنانوي" & \\
\hline- & - & **, orV & ابتدائي & \multirow{3}{*}{ التقويم الذاتي } \\
\hline- & $T, \varepsilon T$ & $* *, 7 \pi \lambda$ & إعدادي & \\
\hline T,T & $\cdot, \cdot 1$ & **.,0TE & لَنانوي & \\
\hline- & - & $* *, \Gamma 19$ & ابتدائي & \multirow{3}{*}{ طلب العون الأكاديمي } \\
\hline- & $\cdot, \Lambda T$ & $* *, \varepsilon, \varepsilon$ & إعدادي & \\
\hline$\cdot, 70$ & $\cdot, 10$ & **, זT & نُانوي & \\
\hline- & - & **, ,OY. & ابتدائي & \multirow{3}{*}{ إدارة الوقت } \\
\hline- & $\cdot, \pi /$ & $* *,, 0 V Y$ & إعدادي & \\
\hline., $0 Y$ & 1,11 & $* *, \pi \mid T$ & لَنانوي & \\
\hline- & - & $* *, \Gamma \wedge \Lambda$ & ابتذائي & \multirow{3}{*}{ ت تعلم الأقران } \\
\hline- & 1,10 & $* *, 0, \mathrm{~V}$ & إعدادي & \\
\hline$\cdot, \mathrm{V} \cdot$ & , , $\leqslant$ & $* *,, \Sigma \Gamma \Gamma$ & تُنانوي & \\
\hline- & - & $* *, 0 Y T$ & ابتذائي & \multirow{3}{*}{ الضبط البيئي الدافعي } \\
\hline- & **Y,Y & $* *, 79 V$ & إعدادي & \\
\hline$T, 1 Y$ & $1,7 \mathrm{~V}$ & **,,T. & لَنانوي" & \\
\hline- & - & $* *, r \wedge$ & ابتذائي & \multirow{3}{*}{ مكافأة الذات } \\
\hline- & $\cdot, \Gamma$ & $* *, 101$ & إعدادي & \\
\hline 1,19 & $1,0 \varepsilon$ & $* *, r, 7$ & نَانوي & \\
\hline- & - & $* *, \Gamma \wedge \Lambda$ & ابتدائي & \multirow{3}{*}{ تتشيط الا هتمام } \\
\hline- & **1,95 & $* *, 070$ & إعدادي & \\
\hline 1,19 & $\cdot, 79$ & $* * \cdot, \leqslant 0 \wedge$ & لَنانوي" & \\
\hline- & - & **, , NTा & ابتذائي & \multirow{3}{*}{ الدرجة الكلية } \\
\hline- & $0, \Lambda Y$ & $* * ., 900$ & إعدادي & \\
\hline 7,11 & $\cdot, \Sigma T$ & $* * \cdot, \lambda \mid \varepsilon$ & لَنانوي & \\
\hline & 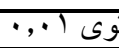 & (د* & مستوى 0. & \\
\hline
\end{tabular}


يتضح من جدول (ع () عدم اختلاف العلاقة بـين اســتر اتيجيات الــتعلم

النظم ذانيا و التحصيل الدر اسي باختلاف المرحلة الدراسية؛ حيث كانت الفـروق غير دالة بين معاملي الارتباط بينهما في كل مرحلـــة مــن المر احـل الــثناث، باستثناء ما يلي:

ا ـ استر اتيجية الضبط البيئي الدافعي، واستر اتيجية تتشيط الاهتمام التي اتـضح وجود فروق دالة بين معاملي الارتباط بين المتغيــرين بالنسـبة لمسـستوى

$$
\text { المرحلة الابتدائية و المرحلة الاعدادية. }
$$

r. استر اتيجية البحث عن المعلومات التي اتضح وجــود فــروق دالـــة بــين

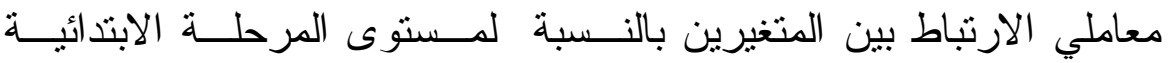
و والثانوية.

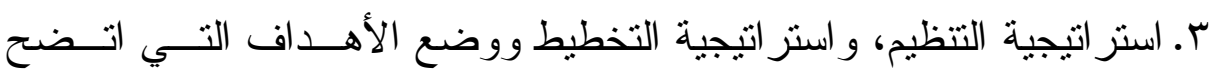
وجود فروق دالة بين معاملي الارتباط بين المتغيـرين بالنـسبة لـــستوى المرحلة الإعدادية و الثانوية. رابعاً: النتائج المتعلقة بالفرض الرابعة وابع: ينص الفرض الرابع على أنه: تختلف استر اتيجيات التعلم المنظم ذاتبا وفقا لمتغير البيئة الثقافية (الحضر والريف). و لاختبار هذا الفرض قام الباحثون باستخدام اختبار (ت) للكثف عن دلالة الفروق بين متوسطي درجات مجمو عتين مسنقلتين، ويوضح جدول (10) دلالة هذه الفروق. 


\section{جدول (10)}

دلالة الفروق بين متوسطات درجات طلاب الحضر ومتوسطات درجات طلاب الريف في

استر اتيجيات التعلم المنظم ذاتيا لكل مرحلة من المراحل التئل الثلاث للتعليم العام

\begin{tabular}{|c|c|c|c|c|c|c|c|c|}
\hline \multirow{2}{*}{ الدالاكة } & \multirow{2}{*}{ قيمة (ت) } & \multirow{2}{*}{ د. } & \multicolumn{2}{|c|}{ طلاب الريف } & \multicolumn{2}{|c|}{ طلاب الحضر } & \multirow{2}{*}{ الاستر اتيجية } & \multirow{2}{*}{ المرحلة } \\
\hline & & & $r \varepsilon$ & $t^{5}$ & $\varepsilon$ & مן & & \\
\hline 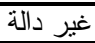 & 1,17 & ITV & $\overline{Y, \cdot V}$ & 11,97 & $\overline{T, Y V}$ & 11,04 & التسميع & \multirow{13}{*}{ 胃 } \\
\hline غير دالة & $1, r 9$ & ITV & $r, \cdots$ & $11, \mathrm{~V}$. & T,IV & $(1, r)$ & التنظيم & \\
\hline غير دالة & $\cdot, 0 \leqslant$ & $1 \pi V$ & $r, .9$ & $\overline{1 \cdot, \lambda r}$ & $r, \cdot 1$ & $11, \cdot r$ & الاحتفاظ بالسجلات & \\
\hline غير دالة & $\cdot, \varepsilon \leqslant$ & 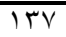 & $r, T$. & $T r, \cdot 1$ & $r, 10$ & $\Pi 1, \lambda \Gamma^{\prime}$ & التخطبط ووضع الأهداف & \\
\hline غير دالة & 1,19 & ITV & $r, r$, & $11,1 \varepsilon$ & 1,94 & 11,00 & البحث عن المعلومات & \\
\hline غير دالة & $\cdot, 7 V$ & ITV & $r, r \cdot$ & $\mid r, 11$ & T,YY & $\overline{11, \lambda \varepsilon}$ & التقويم الذاني & \\
\hline غير دالة & $\cdot, 11$ & ITV & $r, \cdot 1$ & $9, \vee \cdot$ & 1,91 & 9,70 & طلب العون الأكاديمي & \\
\hline غير دالة & $\cdot, 10$ & $1 \pi V$ & $T, Y V$ & $11, V Y$ & $\overline{T, Y T}$ & $11, T Y$ & إدارة الوقت & \\
\hline غير دالة & $\cdot, \Lambda Y$ & ITV & $r, 1 \cdot$ & $1 \cdot, 10$ & $\overline{T, Y Y}$ & $1 \cdot, 00$ & تعلم الأقران & \\
\hline غير دالة & $1,(1)$ & TrV & $\overline{Y, Y Y}$ & 11,19 & $\overline{r, r \varepsilon}$ & $11,1 Y$ & الضبط البيئي الدافعي & \\
\hline غير دالة & $\cdot, \mathrm{r} \cdot$ & $1 \pi V$ & $r, .9$ & $1 \cdot, \leqslant 7$ & Y,Y. & $\overline{1 \cdot, \Gamma \Lambda}$ & مكافأة الذات & \\
\hline غير دالة & $\overline{1, \mu r}$ & irv & $\overline{Y, \cdot Y}$ & $1 \cdot, 90$ & $r, 1$. & $1 \cdot, \varepsilon \wedge$ & تتشيط الاهتمام & \\
\hline غير دالة & $\cdot, 7 \Lambda$ & TrV & 10,9 & $T \pi \xi, 7$ & $1 \leqslant, 7$ & $\overline{I r Y, \Lambda}$ & الارجة الكلية & \\
\hline$\cdot, \cdot 1$ & $r, .0$ & $1 \leqslant V$ & $T, I V$ & $1 \cdot, M$ & $T, 17$ & $\overline{11, \varepsilon Y}$ & التسميع & \multirow{13}{*}{$\begin{array}{l}\overline{\bar{x}_{0}} \\
\bar{y} \\
\overline{3}\end{array}$} \\
\hline$\cdot, ., 1$ & $0, \cdot 7$ & $T \leqslant V$ & $\overline{r, 1 \varepsilon}$ & $1 \cdot, 7$ & I, V. & $T r, r$. & التنظيم & \\
\hline$\cdot, \cdot 1$ & $r, q$. & $1 \leq V$ & $Y, .7$ & $1 \cdot, \leqslant 0$ & 1,97 & 11,19 & الاحتفاظ بالسجلات & \\
\hline$\cdot, \cdot 1$ & $\varepsilon, \wedge 0$ & $1 \leqslant V$ & $\overline{Y, Y}$ & $11, \cdot \varepsilon$ & $\overline{r, \cdot r}$ & $T r, r \cdot$ & التخطيط ووضع الأهداف & \\
\hline$\cdot, \cdot, 1$ & $r, 91$ & $T \leqslant V$ & $1, \wedge 1$ & $1 \cdot, 174$ & 1,90 & 11,71 & البحث عن المعلومات & \\
\hline$\cdot, \cdot, 1$ & $r, 77$ & $T \leqslant V$ & $T, r \varepsilon$ & $11, Y \mu$ & 1,71 & $T, 0 \leqslant$ & التقويم الذاني & \\
\hline$\cdot, \cdot, 1$ & $r, \wedge 0$ & $1 \leqslant V$ & $1, \mathrm{~V}$. & $1 \cdot, 00$ & $\overline{1, \wedge \varepsilon}$ & 11,49 & طلب العون الأكاديمي & \\
\hline$\cdot, \cdot, 1$ & $\varepsilon, .0$ & $1 \leq V$ & $1, \wedge 7$ & $\mid \cdot, 7)$ & $1, \wedge 1$ & $11, \wedge 1$ & إدارة اللوقت & \\
\hline$\cdot, \cdot, 1$ & $r, \cdot 1$ & $1 \leq V$ & 1,99 & $1 \cdot, r 9$ & $r, r$, & $11, \leqslant 7$ & تعلم الأقران & \\
\hline$\cdot, \cdot 1$ & $\varepsilon, \Gamma V$ & $T \leqslant V$ & $\overline{r, r}$. & $\overline{1 \cdot, 14}$ & 1,07 & $\overline{T Y, \Gamma \wedge}$ & الضبط البيئي الدافعي & \\
\hline غير دالة & $1, \sum \Lambda$ & $1 \leqslant V$ & $r, I Y$ & $1 \cdot, 09$ & $r, \cdot r$ & 11,11 & مكافأة الذات & \\
\hline$\cdot, \cdot 1$ & $\varepsilon, r Y$ & $1 \leqslant V$ & $\overline{Y, Y T}$ & $1 \cdot, \leqslant 7$ & $1, \wedge \wedge$ & 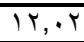 & تتشيط الاهنمام & \\
\hline$\cdot, \cdot, 1$ & 7,7 & $1 \leqslant V$ & $T \varepsilon, V$ & $\overline{T Y V, \Lambda}$ & $1 \cdot, 7$ & $1 \leqslant Y, V$ & الارجة الكلية & \\
\hline$\cdot, \cdot, 1$ & $r, 11$ & 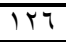 & $1, \leqslant 0$ & $1 \cdot, \cdot 0$ & $\overline{Y, \Sigma Y}$ & $T 1,1 Y$ & التسميع & \multirow{13}{*}{ 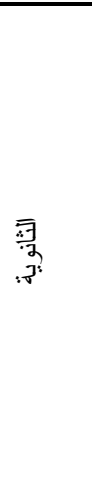 } \\
\hline$\cdot, \cdot, 1$ & $r, 17$ & TKT & 1,19 & $9, V \varepsilon$ & $\overline{Y, \Sigma V}$ & $1 \cdot, 97$ & التنظيم & \\
\hline$\cdot, .0$ & $r, 7 r$ & Tr7 & $1,0 \leqslant$ & 9,97 & $T, \varepsilon r$ & $\overline{1 \cdot, \lambda \Lambda}$ & الاحتفاظ بالسجلات & \\
\hline$\cdot, \cdot, 1$ & $\varepsilon, 9 \varepsilon$ & $1 K 4$ & $1, \wedge \varepsilon$ & $\overline{T \cdot, T}$ & $Y, \cdot V$ & $T, \cdot \cdot \varepsilon$ & التخطيط ووضع الأهداف & \\
\hline$\cdot, .0$ & $r, r \wedge$ & Tr7 & $1, \leqslant V$ & $T \cdot, Y Y$ & $\overline{r, \cdot \varepsilon}$ & $1 \cdot, 97$ & البحث عن المعلومات & \\
\hline$\cdot, \cdot 1$ & $0, \wedge V$ & 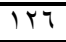 & $1, \mathrm{VV}$ & $T \cdot, Y Y$ & 1,99 & $T r, Y$. & التقويم الذاتي & \\
\hline غير دالة & $1, Y 1$ & $1 \% 7$ & $1, \leqslant 0$ & $1 \cdot, r$ & $Y, \cdot \varepsilon$ & $\mid+, \varepsilon 1$ & طلب العون الأكاديمي & \\
\hline$\cdot, \cdot 1$ & $r, r_{0}$ & TKT & 1,07 & $1 \cdot, Y \Lambda$ & 1,97 & $11, \pi$ & إدارة الوقت & \\
\hline$\cdot, .0$ & $r, I T$ & $1 K 7$ & 1,01 & $1 \cdot, 11$ & $r, r \varepsilon$ & $1 \cdot, \wedge \varepsilon$ & تعلم الأقران & \\
\hline$\cdot, \cdot, 1$ & 0,19 & $1 K 7$ & $1, \wedge \mathrm{V}$ & $1 \cdot, \cdot$, & $Y, \cdot Y$ & $11, \wedge \varepsilon$ & الضبط البيئي الدافعي & \\
\hline$\cdot, .0$ & T,rY & $1 K 7$ & 1,7 & $1 \cdot, 11$ & T,YY & $1 \cdot, 9 Y$ & مكافأة الذات & \\
\hline$\cdot, .0$ & 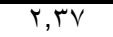 & TK4 & 1,71 & $1 \cdot, \leqslant 9$ & $\overline{Y, Y Y}$ & $11, \pi$ & تتشيط الاهتمام & \\
\hline$\cdot, \cdot, 1$ & $7, \cdot \varepsilon$ & 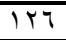 & $\lambda, \Gamma \xi$ & $\mid \pi 1,0$ & $17, r$ & $1 \pi \varepsilon, \Lambda$ & الارجة الكلية & \\
\hline
\end{tabular}


يتضح من جدول (10) عدم وجود فروق بين متوسطات درجات طلاب

الحضر ومتوسطات درجات طلاب الريف في جميع استر اتيجيات التعلم المنظم ذانيا لاى المرحلة الابتدائية، بينما توجد فروق دالة بين متوسطات درجات طلاب الحضر ومتوسطات درجات طلاب الريف في معظم استر اتيجيات التعلم المنظم ذاتيا لدى المرحلة الإعدادية لصالح طلاب الحضر عدا استر اتيجية مكافأة

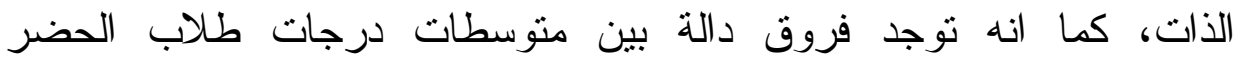
ومنوسطات درجات طلاب الريف في معظم استر اتيجيات التعلم المنظم ذاتيا لاى المرحلة الثانوية لصالح طلاب العضر عدا استراتيجية طلب العون

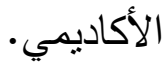

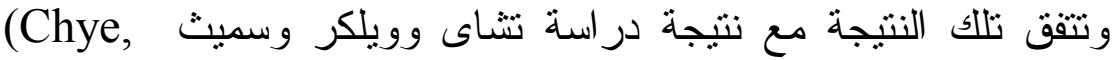
(Wui-Chu, 2004)، ودراسة سوى- كو (Cmith, 1997)

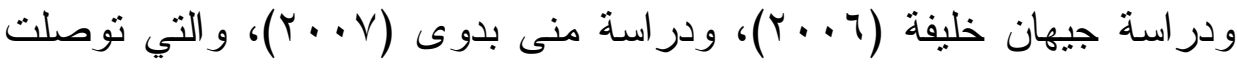
إلى وجود تأثير للبيئة التزبوية والثقافية على سلوك استخدام استراتيجيات التعلم

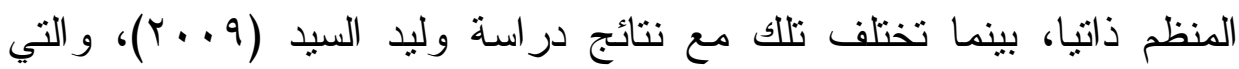
توصلت الى عدم وجود فروقا دالة بين طلاب الحضر وطلاب الريف في استخدام استراتيجيات التعلم المنظم ذاتيا مثل استراتيجية (التكرار، الإتقان،

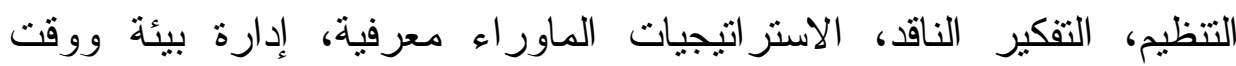
الدر اسة، تتظيم الجهد، تعلم الرفاق، طلب المساعدة). خامساً: النتائج المتعلقة بالفرض الخامس: ينص الفرض الخامس على أنه: تختلف العلاقة بين استراتيجيات التعلم المنظم ذاتيا و التحصيل الدراسي باختلاف البيئة التقافية (الحضر والريف).

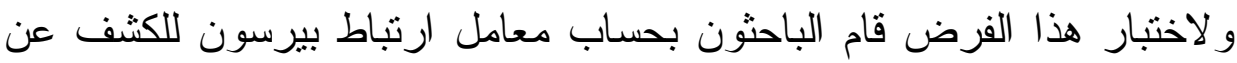


دلالة العلاقة بين درجات استراتيجيات التعلم المنظم ذاتيا ودرجات التحصيل

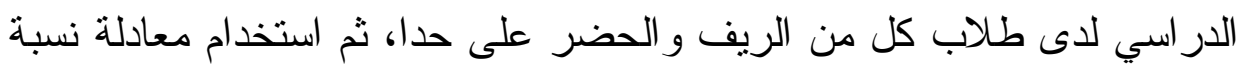
Cohen, Cohen, الارنباط للمجمو عات المستقلة لكو هين، كو هين، ويست و اكين الربن للكثّف عن دلالة الفروق بين كل معاملي ارتباط،

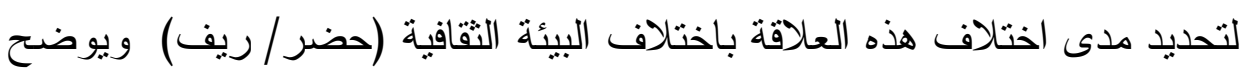
جدول (7 ا (1) دلالة هذه الفروق.

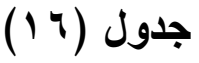

دلالة الفروق بين معاملات الارتباط بين درجات استراتيجيات التعلم

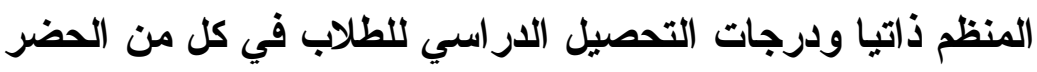

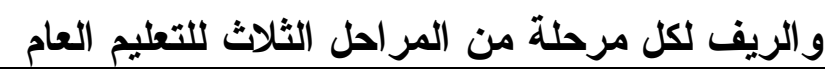

\begin{tabular}{|c|c|c|c|c|c|c|}
\hline \multirow{2}{*}{ مستوى الدلالة } & \multirow{2}{*}{ 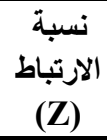 } & \multirow[b]{2}{*}{. } & الريف & الحضر & \multirow[b]{2}{*}{ الاستر اتيجية } & \multirow[b]{2}{*}{ المرحلة } \\
\hline & & & נر & 1 & & \\
\hline غير دالة & $\cdot, \cdot 1$ & ITV & $*, 0$ O & $* *, 01$ & التسميع & \multirow[t]{13}{*}{ الابتدائية } \\
\hline غير دالة & $\cdot, \vee \wedge$ & ITV & $* *, 79$ & $* *, 7)$ & التنظيم & \\
\hline غير دالة & $\cdot, \Gamma \varepsilon$ & ITV & $* *, 09$ & $* *, 00$ & الاحتفاظ بالسجلات & \\
\hline$\cdot, .0$ & $r, I T$ & ITV & $* *, V \vee$ & $* *$, OV & التخطيط ووضع الأهداف & \\
\hline غير دالة & $1, \cdot 1$ & ITV & $* *, \vee \backslash 1$ & $* *, 7)$ & البحث عن المعلومات & \\
\hline$\cdot, \cdot 1$ & $r, 0 \leqslant$ & ITV & $* *, V Y$ & $* *, \leqslant \Gamma$ & التقويم الذاتي & \\
\hline غير دالة & מדו, • & ITV & $* *, r \wedge$ & $* *, \Gamma \wedge$ & طلب العون الأكاديمي & \\
\hline غير دالة & $\cdot, \wedge 9$ & ITV & $* *, 7$. & $* *, \leqslant 9$ & إدارة الوقت & \\
\hline غير دالة & $\cdot, \lambda r$ & ITV & $* *, \leq \wedge$ & * & تعلم الأقر ان & \\
\hline غير دالة & $1, \varepsilon 1$ & ITV & $* *, 7 \leq$ & $* *, \leqslant V$ & الضبط البيئي الدافعي & \\
\hline غير دالة & $\cdot, \leqslant 9$ & ITV & $* *, r q$ & $* *, \leqslant 7$ & مكافأة الذات & \\
\hline غير دالة & $\cdot, Y_{1}$ & ITV & **, & $* *, \leqslant 7$ & تتشيط الاهتمام & \\
\hline$\cdot, .0$ & $Y, \cdot T$ & ITV & $* *, 9 \leq$ & $* *, \wedge \wedge$ & الدرجة الكلية & \\
\hline غير دالة & $\cdot, I V$ & $1 \leqslant V$ & $* *, 0 \mathrm{~V}$ & $* *, 00$ & التسميع & \multirow[t]{4}{*}{ الإعدادية } \\
\hline$\cdot, .0$ & $1,9 r$ & $1 \leq V$ & $* *, 71$ & $* *, \leqslant 7$ & التنظيم & \\
\hline غير دالة & $\cdot, 71$ & $1 \leqslant V$ & $* *, 0 \leq$ & $* *, \leqslant 7$ & الاحتفاظ بالسجلات & \\
\hline غير دالة & $1, \leqslant 1$ & $1 \leqslant V$ & $* *, V \leqslant$ & $* *, 79$ & التخطيط ووضع الأهداف & \\
\hline
\end{tabular}


ج

المجلة العالمية لكلية رياض لطإل

\begin{tabular}{|c|c|c|c|c|c|c|}
\hline \multirow{2}{*}{ الدلالة } & \multirow{2}{*}{$\begin{array}{c}\text { الارتباط } \\
\text { (Z) }\end{array}$} & \multirow[b]{2}{*}{ د.ح. } & الريف & الحضر & \multirow[b]{2}{*}{ الاستر اتيجية } & \multirow{11}{*}{ المرحلة } \\
\hline & & & נر & 1 & & \\
\hline غير دالة & ס ז & $1 \leqslant V$ & $* *, 07$ & $* *, 7$. & البحث عن المعلومات & \\
\hline غير دالة & $1, \leqslant 9$ & $1 \leq V$ & $* *, 79$ & $* *$, or & التقويم الذاتي & \\
\hline غير دالة & $\cdot, \leqslant\rceil$ & $1 \leqslant V$ & $* *, r q$ & $* *, \Gamma Y$ & طلب العون الأكاديمي & \\
\hline غير دالة & I, r & $1 \leq V$ & $* *, 0 \mathrm{~V}$ & 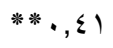 & إدارة الوقت & \\
\hline غير دالة & I, r & $1 \leqslant V$ & $* * *, \Sigma)$ & $* *, O \mathrm{~V}$ & تعلم الأقران & \\
\hline غير دالة & $1, \leqslant \varepsilon$ & $1 \leq V$ & $* *, \vee \cdot$ & $* *, 00$ & الضبط البيئي الدافعي & \\
\hline$\cdot, \cdot 1$ & $r, v q$ & $1 \leq V$ & $* * ., 01$ & $\cdot, \cdot \wedge$ & مكافأة الذات & \\
\hline غير دالة & 1,10 & $1 \leq V$ & $* *, 01$ & שT, • & تتشيط الاهتمام & \\
\hline غير دالة & - & $1 \leqslant V$ & $* * ., 99$ & $* *, 99$ & الدرجة الكلية & \\
\hline غير دالة & $1, v \leq$ & $1 \times 7$ & $* *, \varepsilon 1$ & $* *, 7 \varepsilon$ & التسميع & \multirow[t]{13}{*}{ الثانوية } \\
\hline$\cdot, .0$ & $r, r \wedge$ & 1,7 & $* *, 0$. & $* *, \vee \vee 0$ & 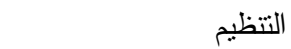 & \\
\hline$\cdot, \cdot 1$ & $r, .0$ & $1 \times 7$ & $* *, \Gamma$ & $* *, \vee V$ & الاحتفاظ بالسجلات & \\
\hline غير دالة & $\cdot, 97$ & 147 & $* *, 71$ & $* *, \vee \backslash$ & التخطيط ووضع الأهد اف & \\
\hline$\cdot, .0$ & $r, I r$ & $1 \times 7$ & $* *, r Y$ & $* *, 7 Y$ & البحث عن المعلومات & \\
\hline غير دالة & $1, \cdot r$ & $1 T^{1}$ & $* *, 0 \leqslant$ & $* *, 77$ & التقويم الذاتي & \\
\hline غير دالة & $1, r_{0}$ & $1 \times 7$ & ***, r T & $* *, 01$ & طلب العون الأكاديمي & \\
\hline$\cdot, \cdot 1$ & $r, q \leq$ & 1,4 & ***, & $* *, \vee \backslash$ & إدارة الوقت & \\
\hline غير دالة & $1,1 \pi$ & 1,7 & $* * *_{\bullet}, \Sigma$. & $* *, 07$ & تعلم الأقران & \\
\hline غبر دالة & $r, 17$ & 1,7 & $* *, 0$ & $* *, \vee v \leqslant$ & الضبط البيئي الدافعي & \\
\hline$\cdot, \cdot 1$ & $r, Y V$ & $1 \times 7$ & $* *, r r$ & $\cdot, 1 \wedge$ & مكافأة الذات & \\
\hline غير دالة & $1, \wedge 1$ & 1,4 & $* *, \varepsilon$ & $* *, 7 \varepsilon$ & تتشيط الاهتمام & \\
\hline غير دالة & - & 1,4 & $* *, 99$ & $* *, 99$ & الدرجة الكلية & \\
\hline
\end{tabular}

يتضح من جدول (17) عدم وجود فروق بين معاملات ارتباط درجات استر اتيجيات التعلم المنظم ذاتياً ودرجات التحصيل الدر اسي بين طلاب الحضر وطلاب الريف في مستوى المرحلة الابتدائية عدا استر اتيجية التخطيط ووضع الأهداف، واستر اتيجية التقويم الذاتي، و الدرجة الكلية، كما أظهرت النتائج عدم وجود فروق بين معاملات ارتباط درجات استراتيجيات التعلم المنظم ذاتيا ودرجات التحصيل الدراسي بين طلاب الحضر وطلاب الريف في مسنوى 
المرحلة الاعدادية عدا استر اتيجية التنظيم واستر اتيجية مكافاة الذات، ويتضح أيضاً عدم وجود فروق دالة بين معاملات ارتباط درجات استر اتيجيات التعلم التهات المنظم ذاتيا ودرجات التحصيل الدراسي بين طلاب الحضر وطلاب الريف للمرحلة الثانوية، عدا خمسة استر اتيجيات هي: استر اتيجية التنظيم، و الاحتفاظ بالسجلات، و البحث عن المعلومات، و إدارة الوقت، ومكافاة الذات.

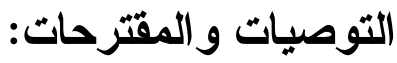

بناء على ما أسفرت عنه الدراسة من نتائج وما اعتمدت عليه من أدبيات ودر اسات سابقة يمكن تقديم التوصيات و المقترحات التالية:

( ) توعية المعلمين بأهية استراتيجيات التعلم المنظم ذاتيا وتوجيهم إلى الى تدريب طلابهم على توظيف هذه الاستر اتيجيات في التعلم و الدر اسة.

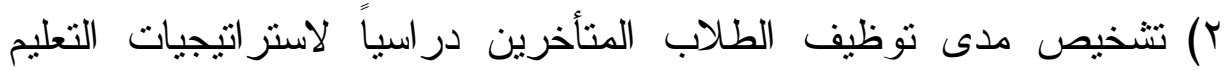
المنظم ذانيا و إعداد البرامج التدريبية اللازمة لتتمية مهار ات استخدام هذه

$$
\text { الاستر اتيجيات في التعلم و الدر اسة. }
$$

r) تضمين استراتيجيات التعلم المنظم ذاتيا ضمن أنشطة المناهج الدراسية

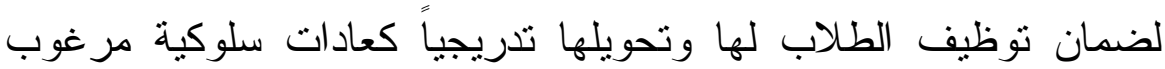

$$
\text { فيها. }
$$

§) إجر اء المزيد من الدر اسات التجريية التي تستهدف تدريب الطلاب وخاصة ذوي الإعاقة و المتأخرين دراسياً على توظيف استر انتجيات التعلم المنظم

$$
\text { ذانياً في التعلم و الدر اسة. }
$$

0) إجراء المزيد من الدراسات النوعية لتحليل برونوكولات التفكير المتعلقة

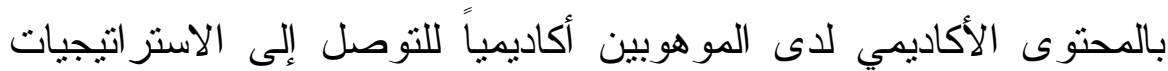
الفعالة التي يستخدمونها في التعلم و الدراسة. 


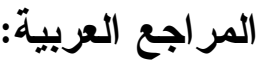

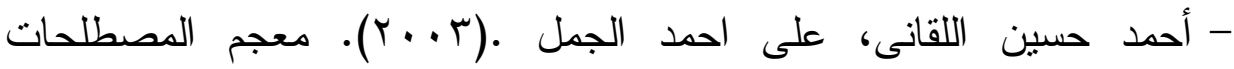
التزبوية المعرفة في المناهج وطرق التدريس، الطبعة الثالثة، عالم الكتب،

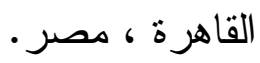

- أحمد على الثريم، زياد كامل اللالا .(10 ب). التعلم المنظم ذاتيا و الدافعية العقلية وعلاقتها بالتحصيل الأكاديمي لدى طلبة قسم التربية الخاصة الدادية

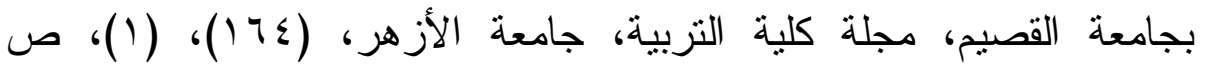
$. T \cdot T-I V V$

- أحمد السويطي. (ع 919). التحصيل الدراسي: أهميته و العوامل المؤثرة فيه.

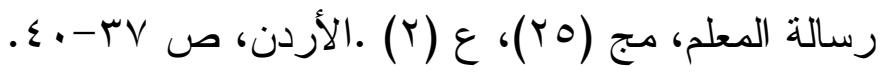

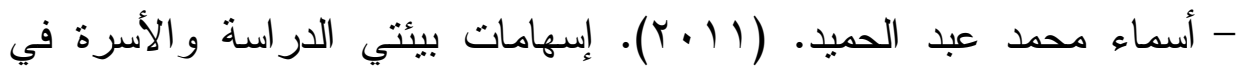
التعلم المنظم ذانيا لاى طلاب المرحلتين الثانوية والجامعية وعلاقته

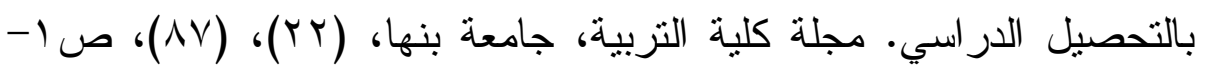
.70

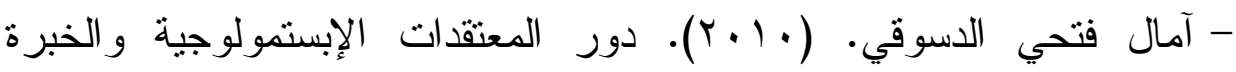
التدريسية في استر اتيجيات التعلم المنظم ذاتيا، رسالة ماجستير غير منشورة، كليه التربية، جامعة عين شمس.

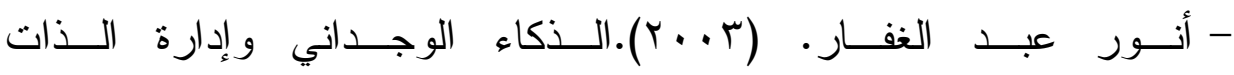

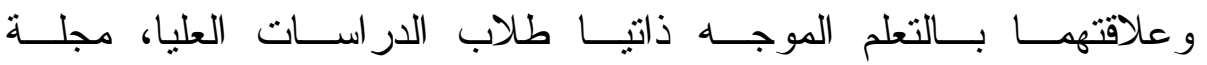

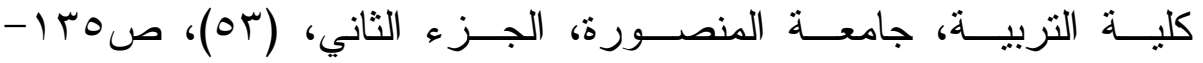
$.17 \mathrm{~V}$ 


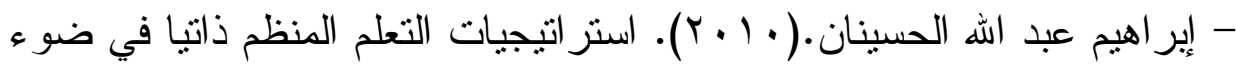
نموذج بينتريش وعلاقتها بالتحصيل و التخصص و المستوى الدراسي و الأسلوب المفضل للتعلم. رسالة ماجستير، كلية العلوم الاجتماعية، جامعة ولئة الإمام محمد بن سعود الإسلامية، الرياض، السعودية.

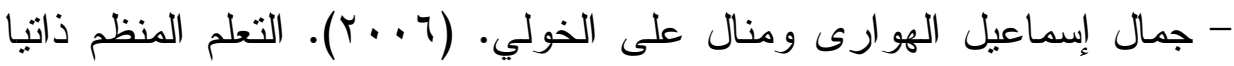
لاى مرتقعي ومنخفضي السعة العقلية من طلاب الجامعة من الجنسين، المجلة المصرية للار اسات النفسية، تصدر ها الجمعية المصرية للار اسات

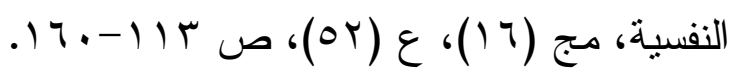

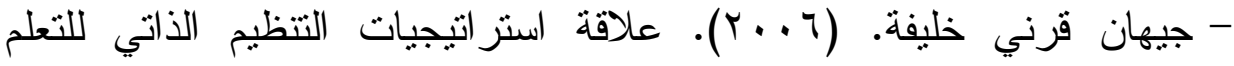
بفاعلية الذات وتصورات التعلم لدى طلاب المرحلة الجامعية، رسالة ماجستير غير منشورة، معهد الدر اسات التربوية، جامعة القاهرة.

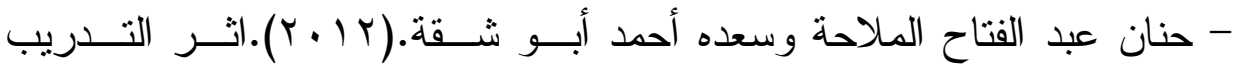
على بعض استر اتيجيات النعلم المنظم ذاتياً في فاعلية الذات وحل الهــشكلات

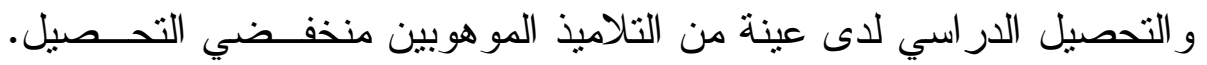

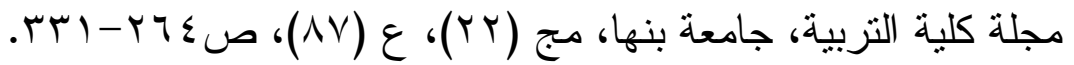

- ربيع أحمد رشوان. (0. . ب). توجهات أهداف الانجاز و المعنقدات الذانية وعلاقتها باستراتيجيات التعلم المنظم ذاتيا لاى طلاب الجامعة، رسالة دكتور اه منشورة، كلية التزبية، جامعة جنوب الو ادي. - ربيع أحمد رشوان. (T . . Y). التعلم المنظم ذاتيا وتوجهات الانجاز : نماذج ودر اسات معاصرة ـ عالم الكتب، القاهرة. 
- ساجدة مطلب طريف. (T (Y). علاقة التعلم المنظم ذاتيا و الدافعية الداخلية بالتحصبل الأكاديمي لدى طلبة جامعة مؤنة، رسالة ماجستير منشورة، جامعة

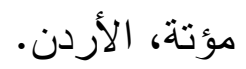

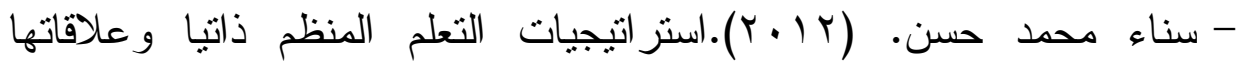
بمهار ات الفهم القرائي لدى تلاميذ الصف الثالث الإعدادي. مجلة القراءة

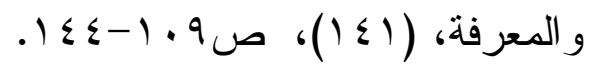

- سهير السعيد جمعة. (11) + (1). استرانيجيات التعلم المنظم ذاتيا وعلاقتها بمهار ات حل المشكلات لدى طلاب المرحلة الثانوية، مجلة القر اءة و المعرفة، $.07-r V$ D מ (IIV)

- عادل محمد العدل.(r . . ץ). ما ور اء المعرفة و الدافعية و استز اتيجيات التنظيم الذاتي للتعلم لدى العاديين وذوى صعوبات التعلم. مجلة كلية التربية، جامعة

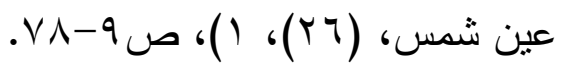

- علاء الدين سعد متولي وعماد احمد حسن. (ع . . (؟). فاعلية برنامج تدريبي مقترح قائم على استر اتيجيات التعلم الذاتي التتظيم في التحصيل الأكاديمي و الأداء التدريبي والاتجاه نحو الاستز اتيجيات المستخدمة لدى طلاب كلية التربية شعبة الرياضيات، مجلة البحوث النفسية والتزبوية، كلية التربية،

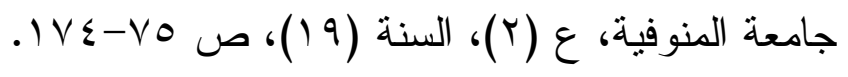
- عبد الرعوف السو اح. (V . . r). اسنز اتيجيات التعلم المنظم ذاتيا لدى الطلاب مرتفعي ومنخفضي التحصيل الدراسي بتخصص إعداد معلم الحاسب الآلي و الإعلام التربوي بكلية التربية النوعية، مجلة بحوث التربية النوعية جامعة

$$
\text { المنصورةة · (1، ص Vrس }
$$


- عبد الناصر أنيس عبد الوهاب. (999 (1). دراسة تحليلية مقارنة لاتجاهات المعلمين نحو تقويم التحصيل الدراسي للطلاب في مراحل التعليم العام

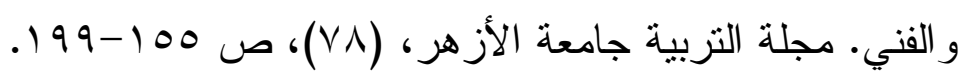

- عبد الناصر الجراح. (• (ب). العلاقة بين التعلم المنظم ذاتيا والتحصيل الأكاديمي لاى عينة من طلبة جامعة اليرموك، المجلة الأردنية في العلوم

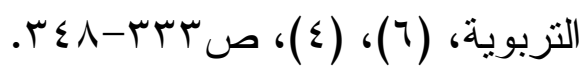

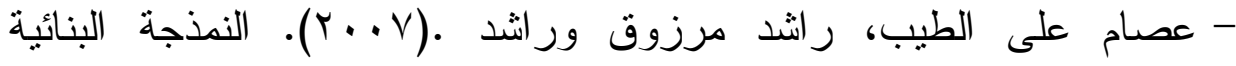
لأساليب المعاملة الو الدية و المعتقدات الدافعية و استر انتجيات التعلم المنظم ذاتياً لاى الطلاب بالمرحلة الثانوية، مجلة البحث في النزبية وعلم النفس، كلية

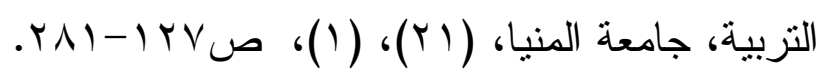

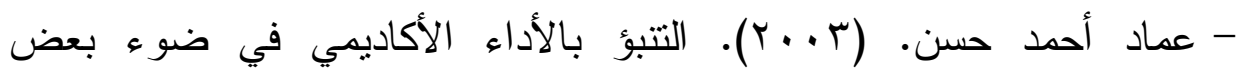
استراتيجيات التعلم المنظم ذانياً لدى طلاب المرحلة الثانوية. مجلة كلية

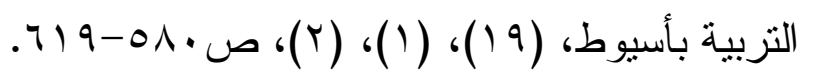

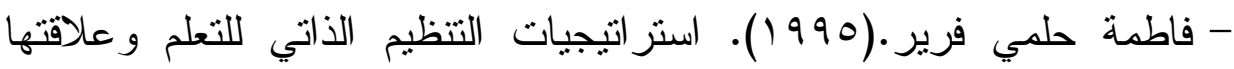
بالتحصيل الدر اسي ومستوى الذكاء لاى طلاب الصف الثاني الإعدادي، مجلة

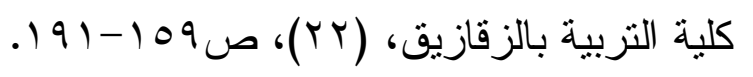

- كمال إسماعيل عطية. ( . . r). العلاقة بين أبعاد التعلم المنظم ذاتيا ودافعية التعلم و التحصيل الدراسي لدى طالبات كلية التزبية بعبرى( سلطنة عمان).

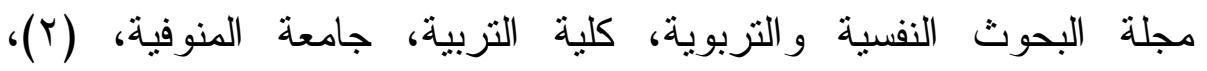

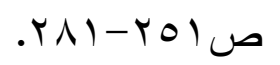


- لطفي عبد الباسط إبر اهيم. (997 (1). مكونات التعلم المنظم ذاتيا في علاقتها بتقدير الذات و التحصيل وتحمل الفشل الأكاديمي، مجلة مركز البحوث بجامعة إيرات

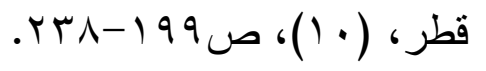

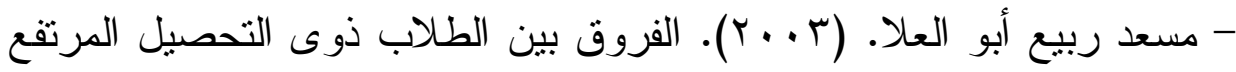
و المنخفض في استر اتيجيات التعلم المنظم ذاتيا وتوجهات الأهداف لدى عينة من طلاب كليات التربية بسلطنة عمان، مجلة البحوث النفسية و التزبوية، كلية

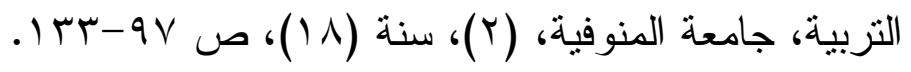

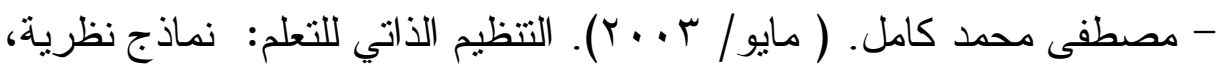
المؤتمر العلمي الثامن عشر لكلية التربية بطنطا (التعلم الذاتي وتحديات

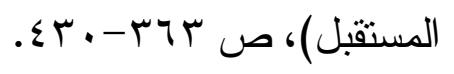

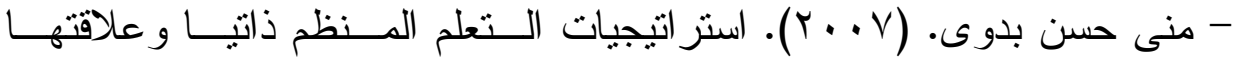

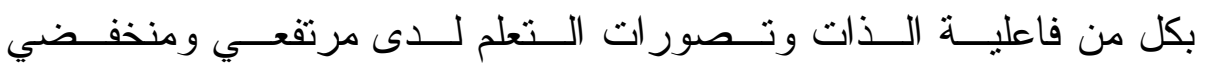

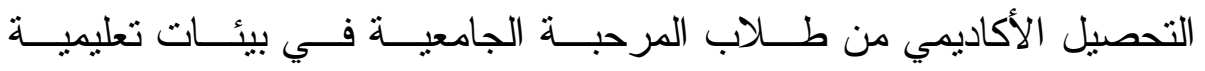

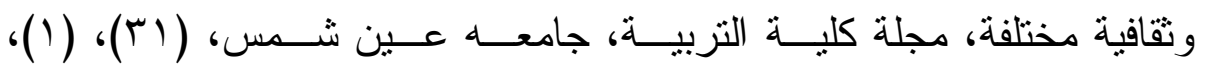

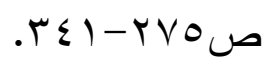

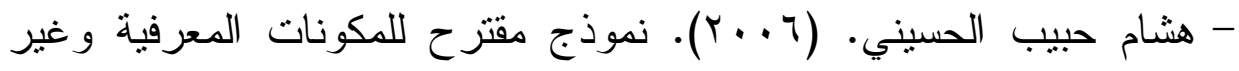

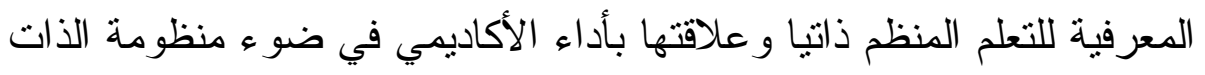

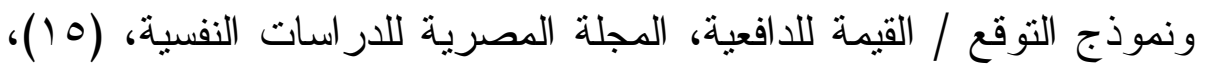

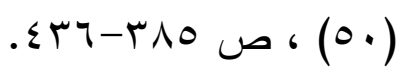

- وصال هاني العمري.(r (ب). درجة امتلاك طلبة المرحلة الأساسية العليا

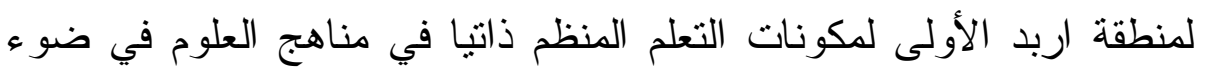


بعض المتغيرات. مجلة الجامعة الإسلامية للاراسات التزبوية و النفسية، مج

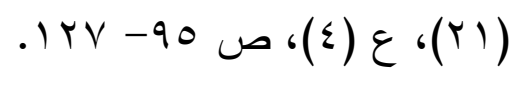

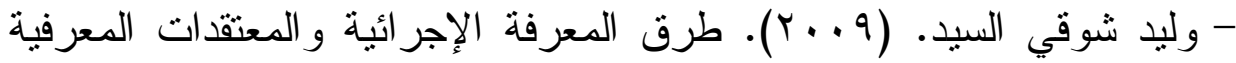
و علاقتها باستراتيجيات التعلم المنظم ذاتبا، رسالة دكتوراه منشورة، كلية

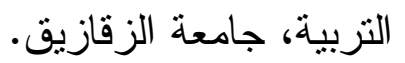

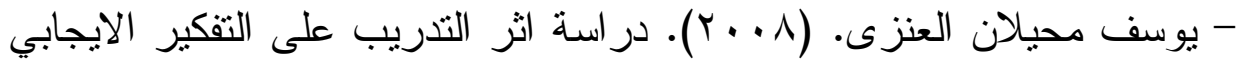

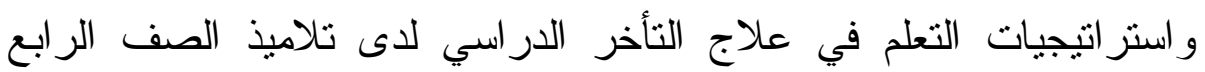
الابتدائي في دولة الكويت، رسالة دكتور اه غير منشورة، معهد الدراسات

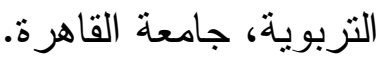

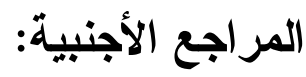

- Ablard, K .\& Lipschultz , R. (1998). Self Regulated Learning in High Achieving Students: Relations to Advanced Reasoning Achievement Goals, and Gender. Journal of Educational Psychology, 94-101

- Bembenutty , H.,(2006). Self Regulated of Learning .Academic Exchange Quarterly ,10,4.

- Boekaerts, M; Rozendaal, J. \& Minnaert, M.(2003). Motivation and self-Regulated Learning in Secondary Vocational Education: Information-Processing Type and Gender Differences. Learning and Individual Differences. 13.4.273-289. 
- Chen, C. (2002). Self -Regulated learning Strategies and Achievement an Introduction to Information System Course, Information Technology, Learning and Performance Journal , 20 (1), 11-25.

- Cohen, J., Cohen, P., West, S. G., \& Aiken, L. S. (2003). Applied Multiple Regression/Correlation Analysis for the Behavioral Sciences. Mahwah, NJ: Erlbaum.

- Chye. S.. Walker. R.A. \& Smith. I.D. (1997). Selfregulated learning in Tertiary Students; The Role of Culture and Self-Efficacy on Strategy use And Academic Achievement Con. Paper Aresented At AARE ference .http://www.swin.edu.au/aare/97.pap/CHYES97350.

- Glenn, M. (2012). Academic Achievement and School Ability: Implications to Guidance and Counseling Programs. Journal of Arts, Science \& Commerce, 2(3) 4955.

- Kitsantas, A. (2000). The Role of Self Regulation Strategies and Self Efficacy Perception in Successful Weigh Loss Maintenance. Psychology and Health, 15,811820.

- Lindner, R., Good Pasture, j. \& Thomas, M. (2007). A Study of The Self Regulated Learning Inventory on

المجلد الثالث


AHBCU Student population in Allied Health. The Internet Journal of Allied Health Sciences and Practice, 5 (4), pp.15.

- Nota, L.; Soresi, S.; \& Zimmerman, B. (2004). Self Regulation and Academic Achievement and Resilience: A longitudinal Study. International Journal of Educational Research, 41, 198-215

- Pelt. J. (2003). The relationship between self-regulated learning and academic achievement in middle school students; A cross cultural perspective. Unpublished Ph.D.University of South Carolina. U.S.A.

- Pintrich, P., \& De Groot, E. (1990). Motivational and SelfRegulated Learning Components of Classroom Academic Performance. Journal of Educational Psychology, 82, 3340.

- Pintrich, P. \& Garcia, T. (1991). Student Goal Orientation And Self-Regulation In The College Classroom. Advances In Motivation And Achievement, 7 (2), 371- 402.

- Pintrich. P. R.. Roeser. R.. \& De Groot. E. (1994). Classroom and Individual Differences in Early Adolescents Motivation and Self-Regulated Learning Journal of Early Adolescence. 14. 139-161. 
- Pintrich, P. (1999). The Role of Motivation in Promoting and Sustaining Self- Regulatory Learning. International journal of educational research, 31(6), pp459- 470

- Pintrich. P. R. (2000). The Role of Goal Orientation in Self Regulated Learning. Cited in M. Boekaerts. P.R. Pintrich \& M. Zeidner (Eds). Handbook of Self Regulation , San Diego. CA: Academic. 451-502..

- Purdie, N. (1994): What do Students Thinks Learning is and How do They do it? Across- Cultural Comparison. Paper Presented at the Annual Conference of the Australian Association for Research in Education, Newcastle, November 1994, 1-23.

- Shin, M . H .(1997) : The Effects of Self Regulated Learning Environment Achievement and Motivation In Problem Solving .Ph.D., The Florida State University.

- Sui-Chu, H. (2004). Self-Regulated Learning and Academic Achievement of Hong Kong Secondary School Students. Education Journal, 32 (2), 87-107.

- Zimmerman, B. Martinez, P. (1986). Development of A structured Interview for Assessing Student use of Self Regulated Learning Strategies. American Educational Research Journal,. 23 (4), 614-628. 
- Zimmerman. B. J.(1989a). Models of Self-Regulated Learning and Learning and Academic Achievement. Cited in B. Zimmerman \& D Schunk (1998). Self Regulated Learning and Academic Achievement: Theory. Research. and Practice. New York. Springer.1 - 25

- Zimmerman, B. \& Martinez-Pons, M. (1990). Student Differences in Self-Regulated Learning: Relating Grade, Sex, and Giftedness to Self-Efficacy and Strategy use. Journal of Educational Psychology, 82, 51-59. 